Prepared in cooperation with the Bureau of Indian Affairs and the Pawnee Nation of Oklahoma

\title{
Cimarron River Alluvial Aquifer Hydrogeologic Framework, Water Budget, and Implications for Future Water Availability in the Pawnee Nation Tribal Jurisdictional Area, Payne County, Oklahoma, 2016-18
}

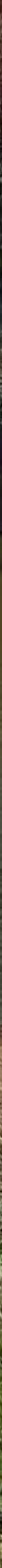


Cover. Photograph showing the Cimarron River in Payne County, Oklahoma, with the view oriented upstream from the right bank about 3 miles north of Ripley, Okla. Photograph by Nicole Paizis, U.S. Geological Survey, March 15, 2018. 


\section{Cimarron River Alluvial Aquifer Hydrogeologic Framework, Water Budget, and Implications for Future Water Availability in the Pawnee Nation Tribal Jurisdictional Area, Payne County, Oklahoma, 2016-18}

By Nicole C. Paizis and Adam R. Trevisan

Prepared in cooperation with the Bureau of Indian Affairs and the Pawnee Nation of Oklahoma

Scientific Investigations Report 2021-5073 


\section{U.S. Geological Survey, Reston, Virginia: 2021}

For more information on the USGS - the Federal source for science about the Earth, its natural and living resources, natural hazards, and the environment—visit https://www.usgs.gov or call 1-888-ASK-USGS.

For an overview of USGS information products, including maps, imagery, and publications, visit https://store.usgs.gov/.

Any use of trade, firm, or product names is for descriptive purposes only and does not imply endorsement by the U.S. Government.

Although this information product, for the most part, is in the public domain, it also may contain copyrighted materials as noted in the text. Permission to reproduce copyrighted items must be secured from the copyright owner.

Suggested citation:

Paizis, N.C., and Trevisan, A.R., 2021, Cimarron River alluvial aquifer hydrogeologic framework, water budget, and implications for future water availability in the Pawnee Nation Tribal jurisdictional area, Payne County, Oklahoma, 2016-18: U.S. Geological Survey Scientific Investigations Report 2021-5073, 49 p., https://doi.org/10.3133/ sir20215073.

Associated data for this publication:

Trevisan, A.R., and Paizis, N.C., 2021, MODFLOW-NWT model used for the simulation of the Cimarron River alluvial aquifer in the Pawnee Nation Tribal jurisdictional area in Payne County, Oklahoma, 2016-17: U.S. Geological Survey data release, https://doi.org/10.5066/P9WZGYQF.

U.S. Geological Survey, 2019, USGS water data for the Nation: U.S. Geological Survey National Water Information System database, https://doi.org/10.5066/F7P55KJN.

ISSN 2328-0328 (online) 


\section{Acknowledgments}

The authors wish to thank the leaders and members of the Pawnee Nation of Oklahoma

(Pawnee Nation) who made this report possible, including Walter Echo-Hawk for his assistance with field logistics and for coordinating efforts to obtain the needed permissions to access the land of the Pawnee Nation. The authors are grateful to the many landowners who provided access to their property for hydrogeologic-data collection.

The authors wish to thank U.S. Geological Survey scientists Shana Mashburn and Kyle Rennell for overseeing and assisting with the data collection. 



\section{Contents}

Acknowledgments .......................................................................................................................ii

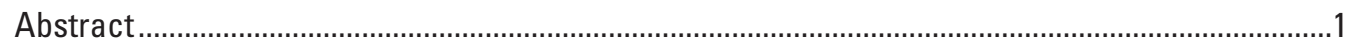

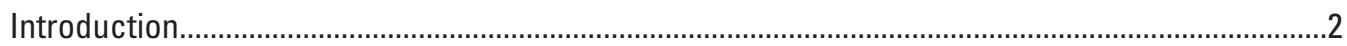

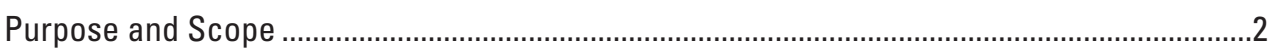

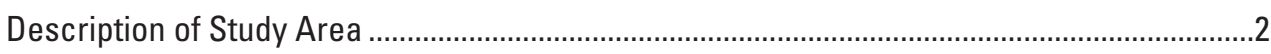

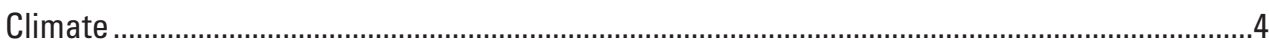

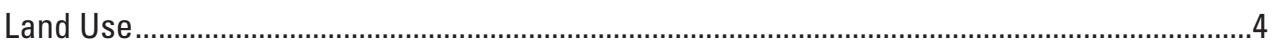

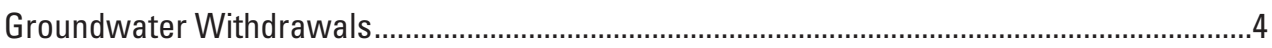

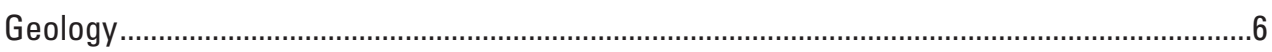

Quaternary Alluvium and Terrace Deposits .............................................................

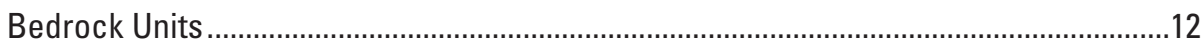

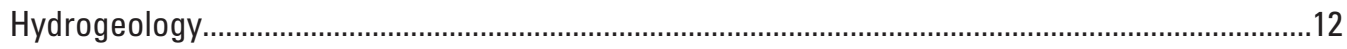

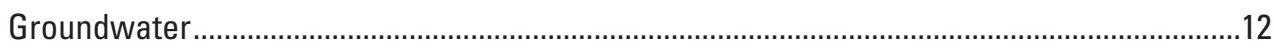

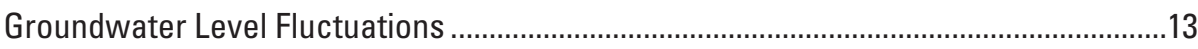

Potentiometric Surface ............................................................................................

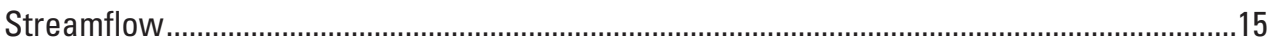

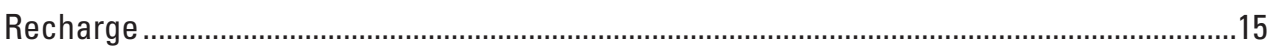

Water-Table Fluctuation Method ............................................................................ 15

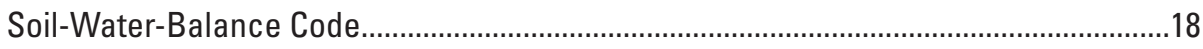

Hydrogeologic Framework of the Cimarron River Alluvial Aquifer .............................................20

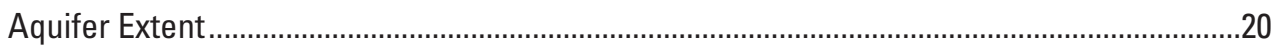

Bedrock Altitudes From Ambient Seismic Method ......................................................20

Aquifer Depths and Thicknesses from Lithologic Logs ...............................................20

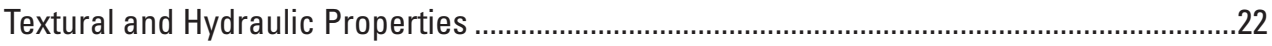

Lithologic Logs and Percent Coarse Values.................................................................22

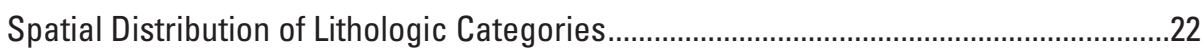

Conceptual Groundwater Flow Model and Water Budget .............................................................2

Hydrologic Boundaries of the Cimarron River Alluvial Aquifer..............................................25

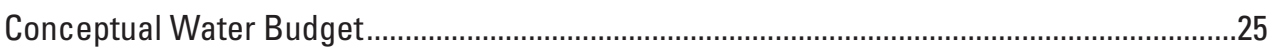

Numerical Groundwater Flow Model of the Cimarron River Alluvial Aquifer .................................27

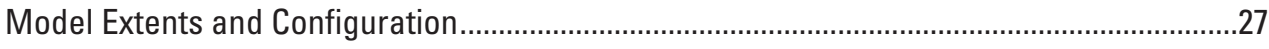

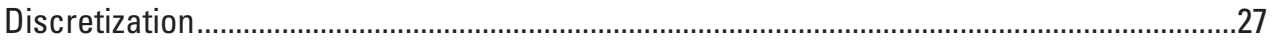

Boundary Conditions of the Numerical Groundwater-Flow Model......................................28

Groundwater Recharge .........................................................................................

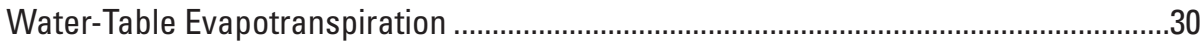

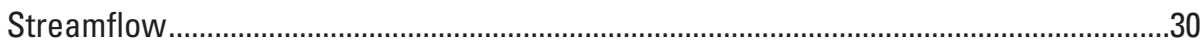

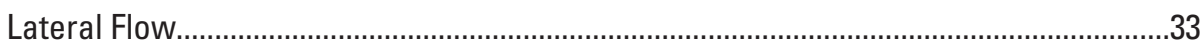

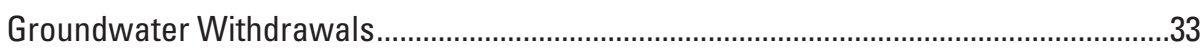

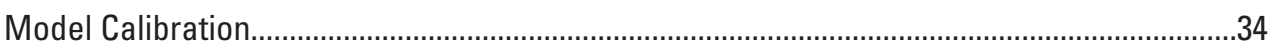

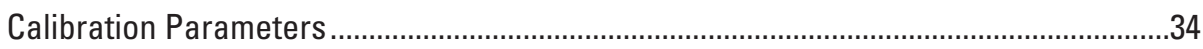

Observations Used for Calibration and Observation Weighting .......................................34

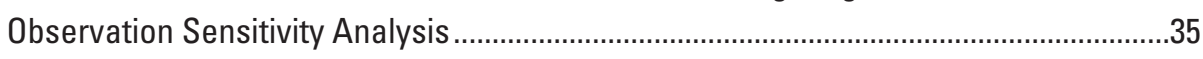

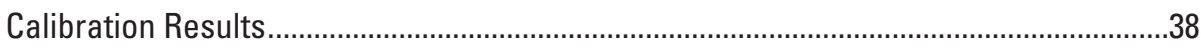




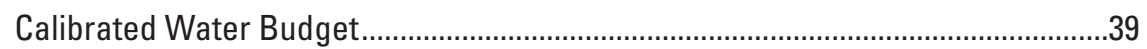

Comparison of Simulated and Observed Values .....................................................39

Long-Term Streamflow Capture Analysis—Implications for Future Water Availability .........40

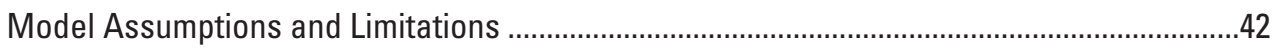

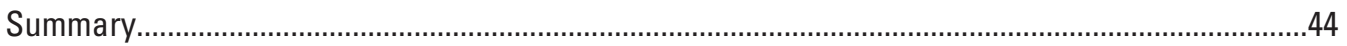

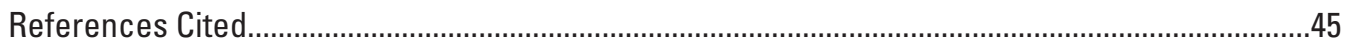

\section{Figures}

1. Map showing the Cimarron River alluvial aquifer, the Cimarron River alluvial aquifer model extent, and the Pawnee Nation subdomain of the Cimarron River alluvial aquifer model extent (Pawnee Nation subdomain) and data collection sites in and near the Pawnee Nation Tribal jurisdictional area in Payne County, Oklahoma

2. Graph showing total annual precipitation and annual mean temperature for each year during the 1994-2019 period of record at the Perkins, Oklahoma, Mesonet weather station near the study area, the Pawnee Nation subdomain of the overall Cimarron River alluvial aquifer model extent, Payne County, north-central Oklahoma

3. Pie charts showing land-cover classifications for the Pawnee Nation subdomain of the Cimarron River alluvial aquifer model extent, 2018, Pawnee Nation Tribal jurisdictional area, Payne County, north-central Oklahoma. .7

4. Map showing land-cover classification for the Pawnee Nation subdomain of the Cimarron River alluvial aquifer model extent, 2018

5. Map showing locations of wells used for permitted groundwater withdrawals in the model area by permitted use and permitted type.

6. Map showing surficial geologic units of the overall Cimarron River alluvial aquifer model extent in Payne County, north-central Oklahoma

7. Diagram showing a simplified aquifer schematic indicating inflows, such as precipitation recharge and bedrock lateral flow, and outflows, such as evapotranspiration, base-flow contributions to streams, and groundwater withdrawals

8. Graph showing depth to water at continuous-monitoring wells and daily precipitation data from the Perkins, Oklahoma, Mesonet weather station, May 2017 to October 2018, used for the water-table fluctuation method for the use in the model.

9. Map showing potentiometric surface of the Cimarron River alluvial aquifer model extent in Payne County, north-central Oklahoma, March 2018 ...

10. Map showing bedrock altitudes and ambient seismic locations and Oklahoma Water Resources Board well logs used to interpolate the base of the Cimarron River alluvial aquifer.

11. Bar graph showing aquifer thickness observation values determined from lithologic logs

12. Chart showing percentage of coarse material multiplier values for the generalized lithologic categories used to obtain horizontal hydraulic conductivity for the Cimarron River alluvial aquifer

13. Bar graph showing percentage of observations of estimated horizontal hydraulic conductivity distributions derived from Oklahoma Water Resources Board lithologic logs for wells completed in the Cimarron River alluvial aquifer 
14. Graphs showing monthly base flows derived using base-flow index methods for streamflow data collected from 2016 to 2017 for selected U.S. Geological Survey streamgages in Payne County, north-central Oklahoma, used for input to the Cimarron River alluvial aquifer model.

15. Map showing modeled land-surface altitudes used in the Cimarron River alluvial aquifer that were derived from a U.S. Geological Survey digital elevation model.

16. Bar graph showing number of modeled land-surface altitude observations for the Cimarron River alluvial aquifer model using 10 bins .

17. Map showing mean recharge during 2016-17 used for the Cimarron River alluvial aquifer steady-state simulation.

18. Map depicting model boundary conditions, stream reaches, and inflow points for the Streamflow-Routing package for the Cimarron River alluvial aquifer simulation.

19. Graph showing monthly water demand as percentage of annual water use for irrigation, public supply, and other usages for the upper Arkansas River Basin .34

20. Map showing locations of water-table altitude observations and map identifier and the extent of terrace deposits.

21. Bar graph showing number of saturated aquifer thickness values assigned to model cells

22. Bar graph showing conceptual groundwater-flow model and simulated water budget for the Pawnee Nation subdomain of the Cimarron River alluvial aquifer model extent, with negative values indicating outflows and positive values indicating inflows

23. Graph showing relation between simulated and observed water-table altitudes between alluvium and terrace deposits, as well as between transient and steady state for the Pawnee Nation subdomain of the Cimarron River alluvial aquifer model.

24. Graphs showing observed versus simulated base flows for transient simulations of the Cimarron River alluvial aquifer model at two U.S. Geological Survey streamgages in the Pawnee Nation subdomain of the overall model area for the Cimarron River alluvial aquifer, Payne County, north-central Oklahoma ....42

25. Map showing streamflow capture for the Pawnee Nation subdomain of the Cimarron River alluvial aquifer model extent, Payne County, north-central Oklahoma

\section{Tables}

1. Total annual precipitation and annual mean temperature data for each year during the 1994-2019 period of record at the Perkins, Oklahoma, Mesonet weather station near the study area, Pawnee Nation subdomain of the overall Cimarron River alluvial aquifer model extent, Payne County, north-central Oklahoma

2. Estimates of annual groundwater-withdrawal rates for the Cimarron River alluvial aquifer model extent based on one-half of the permitted groundwaterwithdrawal rates for well permits, 2016-18. 
3. Seepage-run measurements in order of upstream to downstream at various sampling locations on the Cimarron River and tributaries in the Pawnee Nation subdomain of the overall Cimarron River alluvial aquifer model extent, Payne County, north-central Oklahoma, March 2018

4. Water-table fluctuation method data used to estimate recharge in the Pawnee Nation subdomain of the overall model area for the Cimarron River alluvial aquifer, Payne County, north-central Oklahoma, June 2017 to October 2018

5. Conceptual and simulated water-budget totals for the Pawnee Nation subdomain of the Cimarron River alluvial aquifer model extent.

6. Summary statistics for modeled land-surface altitudes, bedrock altitudes, aquifer thickness, and saturated aquifer thickness for the Cimarron River alluvial aquifer.

7. Hydrologic parameters from the calibrated Cimarron River alluvial aquifer model and from previous studies of alluvial aquifers in Oklahoma.

8. U.S. Geological Survey wells that provided water-table altitude observations used for calibration of the numerical groundwater-flow model of the Cimarron River alluvial aquifer, 2016-17.

9. U.S. Geological Survey wells that provided water-table altitude observations used for calibration of the numerical groundwater-flow model of the Cimarron River alluvial aquifer, 2016-17.

10. Residual and objective function $(\Phi)$ components for the numerical groundwater-flow model of the Cimarron River alluvial aquifer, 2016-17. 


\section{Conversion Factors}

U.S. customary units to International System of Units

\begin{tabular}{|c|c|c|}
\hline Multiply & By & To obtain \\
\hline \multicolumn{3}{|c|}{ Length } \\
\hline inch (in.) & 2.54 & centimeter $(\mathrm{cm})$ \\
\hline inch (in.) & 25.4 & millimeter $(\mathrm{mm})$ \\
\hline foot $(\mathrm{ft})$ & 0.3048 & meter $(\mathrm{m})$ \\
\hline mile (mi) & 1.609 & kilometer $(\mathrm{km})$ \\
\hline \multicolumn{3}{|c|}{ Area } \\
\hline acre & 4,047 & square meter $\left(\mathrm{m}^{2}\right)$ \\
\hline acre & 0.4047 & hectare (ha) \\
\hline square mile $\left(\mathrm{mi}^{2}\right)$ & 259.0 & hectare (ha) \\
\hline square mile $\left(\mathrm{mi}^{2}\right)$ & 2.590 & square kilometer $\left(\mathrm{km}^{2}\right)$ \\
\hline \multicolumn{3}{|c|}{ Volume } \\
\hline acre-foot (acre-ft) & 1,233 & cubic meter $\left(\mathrm{m}^{3}\right)$ \\
\hline acre-foot (acre-ft) & 0.001233 & cubic hectometer $\left(\mathrm{hm}^{3}\right)$ \\
\hline \multicolumn{3}{|c|}{ Flow rate } \\
\hline acre-foot per year (acre-ft/yr) & 0.001233 & cubic hectometer per year $\left(\mathrm{hm}^{3} / \mathrm{yr}\right)$ \\
\hline cubic foot per second $\left(\mathrm{ft}^{3} / \mathrm{s}\right)$ & 0.02832 & cubic meter per second $\left(\mathrm{m}^{3} / \mathrm{s}\right)$ \\
\hline cubic foot per day ( $\left.\mathrm{ft}^{3} / \mathrm{d}\right)$ & 0.02832 & cubic meter per day $\left(\mathrm{m}^{3 / d}\right)$ \\
\hline gallon per minute (gal/min) & 0.06309 & liter per second $(\mathrm{L} / \mathrm{s})$ \\
\hline inch per year (in/yr) & 25.4 & millimeter per year $(\mathrm{mm} / \mathrm{yr})$ \\
\hline \multicolumn{3}{|c|}{ Hydraulic conductivity } \\
\hline foot per day (ft/d) & 0.3048 & meter per day $(\mathrm{m} / \mathrm{d})$ \\
\hline \multicolumn{3}{|c|}{ Leakance } \\
\hline foot per day per foot $([\mathrm{ft} / \mathrm{d}] / \mathrm{ft})$ & 1 & meter per day per meter $([\mathrm{m} / \mathrm{d}] / \mathrm{m})$ \\
\hline
\end{tabular}

International System of Units to U.S. customary units

\begin{tabular}{|c|c|c|}
\hline Multiply & By & To obtain \\
\hline \multicolumn{3}{|c|}{ Length } \\
\hline millimeter (mm) & 0.03937 & inch (in.) \\
\hline meter $(\mathrm{m})$ & 3.281 & foot $(\mathrm{ft})$ \\
\hline \multicolumn{3}{|c|}{ Flow rate } \\
\hline meter per second $(\mathrm{m} / \mathrm{s})$ & 3.281 & foot per second (ft/s) \\
\hline
\end{tabular}

Temperature in degrees Fahrenheit $\left({ }^{\circ} \mathrm{F}\right)$ may be converted to degrees Celsius $\left({ }^{\circ} \mathrm{C}\right)$ as follows:

${ }^{\circ} \mathrm{C}=\left({ }^{\circ} \mathrm{F}-32\right) / 1.8$. 


\section{Datum}

Vertical coordinate information is referenced to the North American Vertical Datum of 1988 (NAVD 88).

Horizontal coordinate information is referenced to the North American Datum of 1983 (NAD 83).

Altitude, as used in this report, refers to distance above the vertical datum.

\section{Abbreviations}

$\begin{array}{ll}\text { BFI } & \text { base-flow index } \\ \text { DEM } & \text { digital elevation model } \\ \text { ET } & \text { evapotranspiration } \\ \text { GHB } & \text { General-Head Boundary } \\ \text { HOB } & \text { Head Observation } \\ \text { HVSR } & \text { horizontal-to-vertical spectral ratio } \\ \text { NHDPlus } & \text { National Hydrography Dataset Plus } \\ \text { NWIS } & \text { National Water Information System } \\ \text { OWRB } & \text { Oklahoma Water Resources Board } \\ \text { PEST } & \text { parameter estimation tool } \\ \text { RMSE } & \text { root mean square error } \\ \text { SFR } & \text { Streamflow-Routing } \\ \text { SWB } & \text { Soil-Water-Balance } \\ \text { USGS } & \text { U.S. Geological Survey } \\ \text { WEL } & \text { Well } \\ \text { WTF } & \text { water-table fluctuation }\end{array}$




\title{
Cimarron River Alluvial Aquifer Hydrogeologic Framework, Water Budget, and Implications for Future Water Availability in the Pawnee Nation Tribal Jurisdictional Area, Payne County, Oklahoma, 2016-18
}

\author{
By Nicole C. Paizis and Adam R. Trevisan
}

\section{Abstract}

The Cimarron River is a free-flowing river and is a major source of water as it flows across Oklahoma. Increased demand for water resources within the Cimarron River alluvial aquifer in north-central Oklahoma (primarily in Payne County) has led to increases in groundwater withdrawals for agriculture, public, irrigation, industrial, and domestic supply purposes. The Pawnee Nation of Oklahoma (Pawnee Nation) is particularly concerned about the sustainability of the Cimarron River alluvial aquifer and whether the aquifer will continue to be a viable water resource for future generations of Tribal members and residents. To better understand current (2021) water resources and possible future water availability in the Pawnee Nation Tribal jurisdictional area, the U.S. Geological Survey, in cooperation with the Bureau of Indian Affairs and the Pawnee Nation of Oklahoma, compiled available hydrogeologic data and developed conceptual and numerical groundwater-flow models for the Cimarron River alluvial aquifer in Payne County, north-central Oklahoma, including a focus area in the Pawnee Nation Tribal jurisdictional area for the 2016-18 study period.

A conceptual water budget was created to establish estimates of groundwater fluxes into and out of the aquifer through hydrologic boundaries and groundwater withdrawals for use in the numerical groundwater-flow model. The conceptual water budget focuses on the alluvial aquifer, meaning that inflows include sources of water to the aquifer and that outflows include sources of water out of the aquifer, such as base-flow contributions to the Cimarron River. The conceptual water budget was constructed by using data from 2017 (the most complete year of record for each data type included in the model) for the Pawnee Nation subdomain of the Cimarron River alluvial aquifer model extent (Pawnee Nation subdomain).

Groundwater withdrawals were estimated from groundwater-withdrawal rate information for permanent and temporary permitted wells that was obtained from the Oklahoma Water Resources Board. One-half of each annual permitted groundwater-withdrawal rate allotted was used as the estimated annual groundwater-withdrawal amount. Halving the permitted groundwater-withdrawal rate was done because permitted withdrawal rates are the maximum permitted rate and actual groundwater withdrawals are generally appreciably lower than the maximum permitted rate. Total groundwater withdrawals were estimated as 1,300 acre-feet per year for the Pawnee Nation subdomain. Various hydrogeologic data were measured to assist with model development, including depth to bedrock and water-table altitude data. In support of the model development, analyses pertaining to groundwater flow, groundwater/surface-water interactions, base flows in the Cimarron River, and lithological interpretations in the Pawnee Nation Tribal jurisdictional area were used to compute a conceptual water budget applicable to the 2016-18 study period. A numerical groundwater-flow model was developed using the hydrogeologic framework of the Cimarron River alluvial aquifer and the conceptual water budget. The numerical model consists of a single layer representing alluvium and terrace deposits within the alluvial aquifer model area. Hydraulic conductivities were estimated and modeled for the alluvium and terrace deposits in the alluvial aquifer. Base-flow values were estimated using the base-flow index from streamflow data collected at U.S. Geological Survey streamgages. Stream seepage values were derived from the mean 2017 base-flow index between certain streamgages. Hydraulic conductivities were specified an initial (before calibration) value of 120 feet per day for the alluvium deposits and 16 feet per day for the terrace deposits.

The simulated inflows in the numerical groundwaterflow model of the Pawnee Nation subdomain were higher than the inflows of conceptual water budget, and the simulated outflows were lower than the outflows of the conceptual water budget. Overall, simulated base flows matched closely to observed base flows for the 2016 and 2017 stress periods. Simulated streamflow tended to match better with the observed streamflow for 2017, which was the period with the most data for the Cimarron River alluvial aquifer model. 
Streamflow capture analysis was applied to the steadystate simulation to identify areas of the aquifer where base flows in the Cimarron River were most sensitive to groundwater withdrawals. The initial base-flow value was assigned the value obtained from streamflow-routing software used to simulate stream outflow for the calibrated steady-state base model. Subsequent simulations were run in each active cell in the Pawnee Nation subdomain for a specified groundwaterwithdrawal rate of 180,000 cubic feet per day. The study area that includes the Pawnee Nation subdomain is in the upper Arkansas River Basin. A groundwater-withdrawal rate of 180,000 cubic feet per second per day represents a 34 percent increase compared to the highest permitted groundwaterwithdrawal rate for the study area, which corresponds to the estimated 34 percent increase in groundwater withdrawals predicted by 2060 for the upper Arkansas River Basin. Simulated streamflow capture was highest in the alluvium deposits adjacent to the Cimarron River; that is, base flow in the Cimarron River decreased the most for simulated groundwater withdrawals in the alluvium deposits adjacent to the Cimarron River. Streamflow capture increased as the distance of a well from the Cimarron River decreased in the simulation. The northeastern part of the Pawnee Nation subdomain showed greater streamflow capture in a broader area; streamflow in that part of the Pawnee Nation subdomain is likely more sensitive to groundwater withdrawals compared to other parts of the Pawnee Nation subdomain.

\section{Introduction}

Increased demand for water resources within the Cimarron River alluvial aquifer in north-central Oklahoma (primarily in Payne County, fig. 1) has led to increases in groundwater withdrawals for agriculture, public, irrigation, industrial, and domestic supply purposes (Oklahoma Water Resources Board [OWRB], 2019a). The Pawnee Nation of Oklahoma (Pawnee Nation) is particularly concerned about the sustainability of the Cimarron River alluvial aquifer and whether the aquifer will continue to be a viable water resource for future generations of Tribal members and residents. Additional industrial and agricultural groundwater withdrawals and surface-water diversions have been proposed within the Pawnee Nation Tribal jurisdictional area (Charles, 2014). As new areas within the jurisdictional area are developed for urban, agricultural, and industrial uses, increased groundwater withdrawals may result in decreases in available water resources and potentially cause conflicts between water users. To better understand current (2021) water resources and possible future water availability in the Pawnee Nation Tribal jurisdictional area, the U.S. Geological Survey (USGS), in cooperation with the Bureau of Indian Affairs and the Pawnee Nation, compiled available hydrogeologic data and developed conceptual and numerical groundwater-flow models for the
Cimarron River alluvial aquifer in Payne County, north-central Oklahoma, including a focus area in the Pawnee Nation Tribal jurisdictional area.

\section{Purpose and Scope}

This report documents the development of conceptual and numerical groundwater-flow models designed to assist water managers in evaluating water resources in and near the Pawnee Nation Tribal jurisdictional area in Payne County, Oklahoma. Various hydrogeologic data collected to assist with model development are described, including depth to bedrock and water-table altitude data. This report includes data and analyses pertaining to groundwater flow, including an assessment of groundwater/surface-water interactions, base flows in the Cimarron River, and lithological interpretations in the Pawnee Nation Tribal jurisdictional area that were used to characterize the hydrogeologic framework. From these data and analyses a conceptual water budget applicable to the 2016-18 study period was developed. A numerical groundwater-flow model was developed using the hydrogeologic framework of the Cimarron River alluvial aquifer and the conceptual water budget. The numerical groundwater-flow model is designed for evaluating the current (2021) water resources of the Pawnee Nation and for assessing the possible effects that proposed new water-resource development (such as additional diversion of surface water and withdrawal of groundwater) might have on future water availability. In addition to the calibrated numerical groundwater-flow model, future water-availability scenarios were archived and released in a companion USGS data release (Trevisan and Paizis, 2021). The focus area for this evaluation of groundwater and surface-water resources is the Pawnee Nation subdomain of the Cimarron River alluvial aquifer model extent (hereinafter referred to as the "Pawnee Nation subdomain") (fig. 1).

\section{Description of Study Area}

The study area is mostly in Payne County in north-central Oklahoma (fig. 1) (Trevisan and Paizis, 2021) and is part of the upper Arkansas River Basin (OWRB, 2012). The southern part of the Pawnee Nation Tribal jurisdictional area overlies the Cimarron River alluvial aquifer in Payne County along the northern banks of the Cimarron River. The Cimarron River originates in New Mexico and terminates at its confluence with the Arkansas River east of Payne County and the Pawnee Nation Tribal jurisdictional area. The Cimarron River is a freeflowing river and is a major source of water as it flows across Oklahoma. Adjoining and below the bed of the Cimarron River are alluvium and terrace deposits that contain groundwater and are referred to in this report as the "Cimarron River alluvial aquifer" (fig. 1). Below and adjoining the alluvial aquifer are bedrock aquifers, such as the Central Oklahoma 


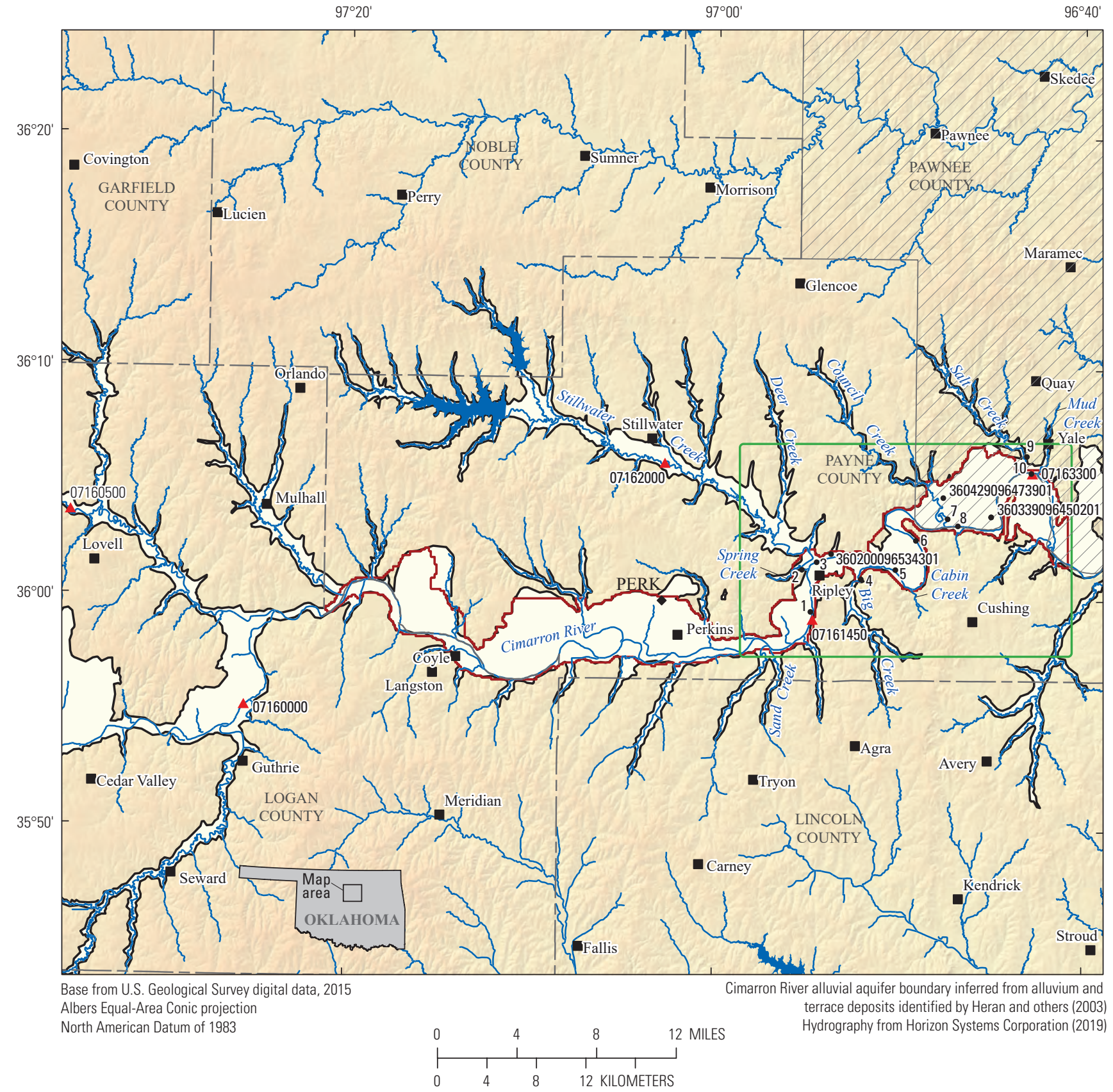

EXPLANATION

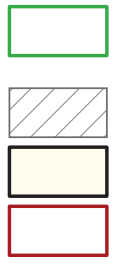

Pawnee Nation subdomain area of the overall Cimarron River alluvial aquifer model extent

Pawnee Nation Tribal jurisdictional area

Cimarron River alluvial aquifer extent

Overall model area for the Cimarron River alluvial aquifer

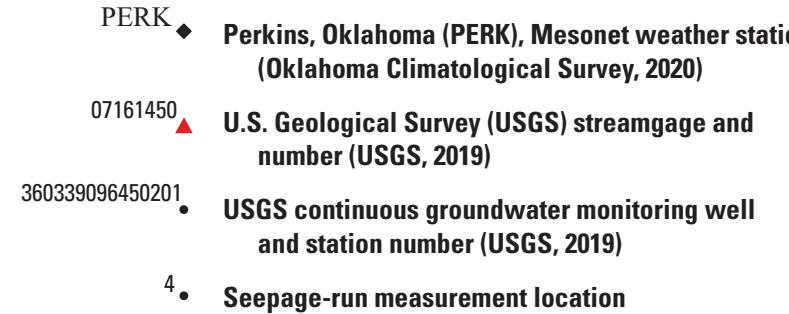

Figure 1. The Cimarron River alluvial aquifer, the Cimarron River alluvial aquifer model extent, and the Pawnee Nation subdomain of the Cimarron River alluvial aquifer model extent (Pawnee Nation subdomain) and data collection sites in and near the Pawnee Nation Tribal jurisdictional area in Payne County, Oklahoma. 
aquifer (known locally and referred to hereinafter as the "Garber-Wellington aquifer") and the Ada-Vamoosa aquifer (Ryder, 1996).

The study area for the numerical groundwater-flow model documented in this report is the extent of the Cimarron River alluvium and terrace deposits between USGS streamgage 07161450 Cimarron River near Ripley, Okla. (hereinafter referred to as the "Ripley streamgage"), and USGS streamgage 07163300 Cimarron River near Yale, Okla. (hereinafter referred to as the "Yale streamgage"), an area of approximately 43 square miles $\left(\mathrm{mi}^{2}\right)$ that is hereinafter referred to as the "Pawnee Nation subdomain" (fig. 1). Most of the analyses and statistics were completed on the Cimarron River alluvium and terrace deposits in the Pawnee Nation subdomain (fig. 1). For model calibration purposes, the overall Cimarron River alluvial aquifer model extent is a $98 \mathrm{mi}^{2}$ area that incorporates streamflow data from USGS streamgage 07160500 Skeleton Creek near Lovell, Okla. (hereinafter referred to as the "Lovell streamgage") and USGS streamgage 07160000 Cimarron River near Guthrie, Okla. (hereinafter referred to as the "Guthrie streamgage").

\section{Climate}

The study area is in the humid subtropical climate division (National Oceanic and Atmospheric Administration, 2019). From May 2016 to October 2018, daily mean temperatures recorded at the Perkins, Okla., Mesonet weather station (fig. 1), about 10 miles southwest of the study area, ranged from 10 to 92 degrees Fahrenheit $\left({ }^{\circ} \mathrm{F}\right)$ (Oklahoma Climatological Survey, 2020). The mean annual temperature during 1997-2019 was $60.63^{\circ} \mathrm{F}$ at the Perkins, Okla., Mesonet weather station (Oklahoma Climatological Survey, 2020) (fig. 2; table 1). The warmest temperatures were typically measured in July, and the coldest temperatures were typically measured in January (National Agricultural Statistics Service, 2018a). The mean annual precipitation was 35.32 inches (in.) at the Perkins, Okla., Mesonet weather station during 1994-2019 (Oklahoma Climatological Survey, 2020) (table 1). The wettest months were typically April and May, and the driest months were typically January and February. Precipitation accounts for most of the recharge to Cimarron River alluvial aquifer (Oklahoma Climatological Survey, 2020).

\section{Land Use}

The CropScape database was used to describe landcover classification at a 30-meter resolution for the Pawnee Nation subdomain of the Cimarron River alluvial aquifer model extent (fig. 1) (National Agricultural Statistics Service, 2018b). In 2018, the Pawnee Nation subdomain was composed primarily of the following land-use types: grassland/pasture (45.3 percent), forest (23.5 percent), and crops (17.5 percent) (figs. 3 and 4). The remaining land-use types were open water (6.7 percent), developed (5.5 percent), barren (1.3 percent), and wetlands ( 0.2 percent). The land classified as crops was further divided into specific crop-cover types and included winter wheat (56.9 percent), alfalfa (the predominant type of hay) (12.0 percent), and soybeans (9.9 percent). Fallow or idle cropland made up 4.3 percent; combined, other types of nonalfalfa hay, corn, and rye accounted for less than 15 percent of the land classified as crops.

\section{Groundwater Withdrawals}

Groundwater withdrawals from the Cimarron River alluvial aquifer in the Pawnee Nation Tribal jurisdictional area during 2016-18 were estimated from water-use permit information from the OWRB (2019a). The OWRB permits all groundwater withdrawals in Oklahoma for nondomestic use. Domestic use has a broad definition that includes withdrawals by a household or individual for household purposes and withdrawals for small-scale farming or irrigation of an area not greater than 3 acres (82 OK Stat. § 105.1).

Most groundwater permits were designated as vested or regular. Vested permits are water-use permits that were established before 1963 and were grandfathered into the current permit system, which was established in 1963 and most recently updated on September 14, 2018. Regular permits are approved for a proportionate amount of water determined by the maximum annual yield of the basin and the percentage of the land overlying the basin that is owned or leased by the applicant. The remaining permits are designated as temporary permits, which include seasonal or term permits. These permits are typically issued for shorter timeframes (less than 1 year) and are given lower priority for withdrawals than permanent or vested permits are given (82 OK Stat. § 105.13).

Groundwater withdrawals were estimated for this study as one-half of the annual permitted groundwater-withdrawal rates for each well (OWRB, 2019a). Halving the permitted withdrawal rate was done because permitted withdrawal rates are the maximum permitted rate and actual withdrawal rates are likely appreciably less than this rate; using one-half of the permitted withdrawal rate to estimate groundwater withdrawals was done based on work published in a recent groundwater modeling report for a similar alluvial aquifer system in Oklahoma (Smith and others, 2021). In their summary of groundwater use from the Salt Fork Red River aquifer in southwestern Oklahoma during 1967-2015, Smith and others (2021) reported that annual reported groundwater use was about 47 percent of the annual permitted groundwater rates for the entire period of record and about 56 percent of the annual permitted withdrawal rates during 2010-15. The Salt Fork Red River aquifer in southwestern Oklahoma has similar hydrogeologic, climatic, and water-use characteristics as the Cimarron River alluvial aquifer described herein, and the groundwater modeling dynamics of the two alluvial aquifers are similar. Smith and others (2021) reported that halving the withdrawal rate improved model stability. Halving the withdrawal rate also improved model stability for this assessment 
Table 1. Total annual precipitation and annual mean temperature data for each year during the 1994-2019 period of record at the Perkins, Oklahoma, Mesonet weather station (Oklahoma Climatological Survey, 2020) near the study area, Pawnee Nation subdomain of the overall Cimarron River alluvial aquifer model extent, Payne County, north-central Oklahoma.

[--, not available]

\begin{tabular}{|c|c|c|}
\hline Year & Total annual precipitation, in inches & $\begin{array}{c}\text { Annual mean temperature, in degrees } \\
\text { Fahrenheit }\end{array}$ \\
\hline 1994 & 33.52 & -- \\
\hline 1995 & 42.50 & -- \\
\hline 1996 & 22.16 & -- \\
\hline 1997 & 35.72 & 62.18 \\
\hline 1998 & 39.87 & 62.27 \\
\hline 1999 & 37.52 & 61.48 \\
\hline 2000 & 34.44 & 60.22 \\
\hline 2001 & 32.08 & 60.97 \\
\hline 2002 & 33.94 & 59.35 \\
\hline 2003 & 32.29 & 59.82 \\
\hline 2004 & 34.28 & 60.01 \\
\hline 2005 & 30.93 & 60.74 \\
\hline 2006 & 24.90 & 62.50 \\
\hline 2007 & 51.24 & 60.22 \\
\hline 2008 & 39.64 & 59.27 \\
\hline 2009 & 37.27 & 59.08 \\
\hline 2010 & 34.30 & 59.99 \\
\hline 2011 & 26.33 & 61.86 \\
\hline 2012 & 24.07 & 63.65 \\
\hline 2013 & 39.16 & 58.56 \\
\hline 2014 & 27.37 & 59.09 \\
\hline 2015 & 42.22 & 60.57 \\
\hline 2016 & 29.23 & 62.28 \\
\hline 2017 & 41.41 & 61.56 \\
\hline 2018 & 39.01 & 59.48 \\
\hline 2019 & 53.01 & 59.28 \\
\hline Mean & 35.32 & 60.63 \\
\hline Standard deviation & 7.52 & 1.37 \\
\hline
\end{tabular}

of the Cimarron River alluvial aquifer. The estimated groundwater withdrawal rates totaled 2,956 acre-feet per year (acre$\mathrm{ft} / \mathrm{yr}$ ) for the Cimarron River alluvial aquifer model extent (fig. 1; table 2). Considering the combined total for permanent and temporary permits, the estimated groundwater withdrawals of 1,443 acre-ft/yr for irrigation accounted for the majority of total withdrawals in the Cimarron River alluvial aquifer model extent, followed by 774 acre-ft/yr for other withdrawals and $739 \mathrm{acre}-\mathrm{ft} / \mathrm{yr}$ for public-supply withdrawals (table 2). The groundwater withdrawals for the Pawnee Nation subdomain represent about 40 percent of the total withdrawals for the entire model extent (table 2).
The number of surface-water permits was low for the Cimarron River alluvial aquifer model extent. Only a few locations had permitted surface-water diversions, and all the permits that were used were active from 1950 to 2018 (OWRB, 2019b). The permitted surface-water withdrawals were on tributaries to the Cimarron River that were not simulated in the model. Because the locations of the permitted surface-water withdrawals were not simulated in the model, surface-water withdrawals were not incorporated into the model or used to estimate surface-water withdrawal rates. 


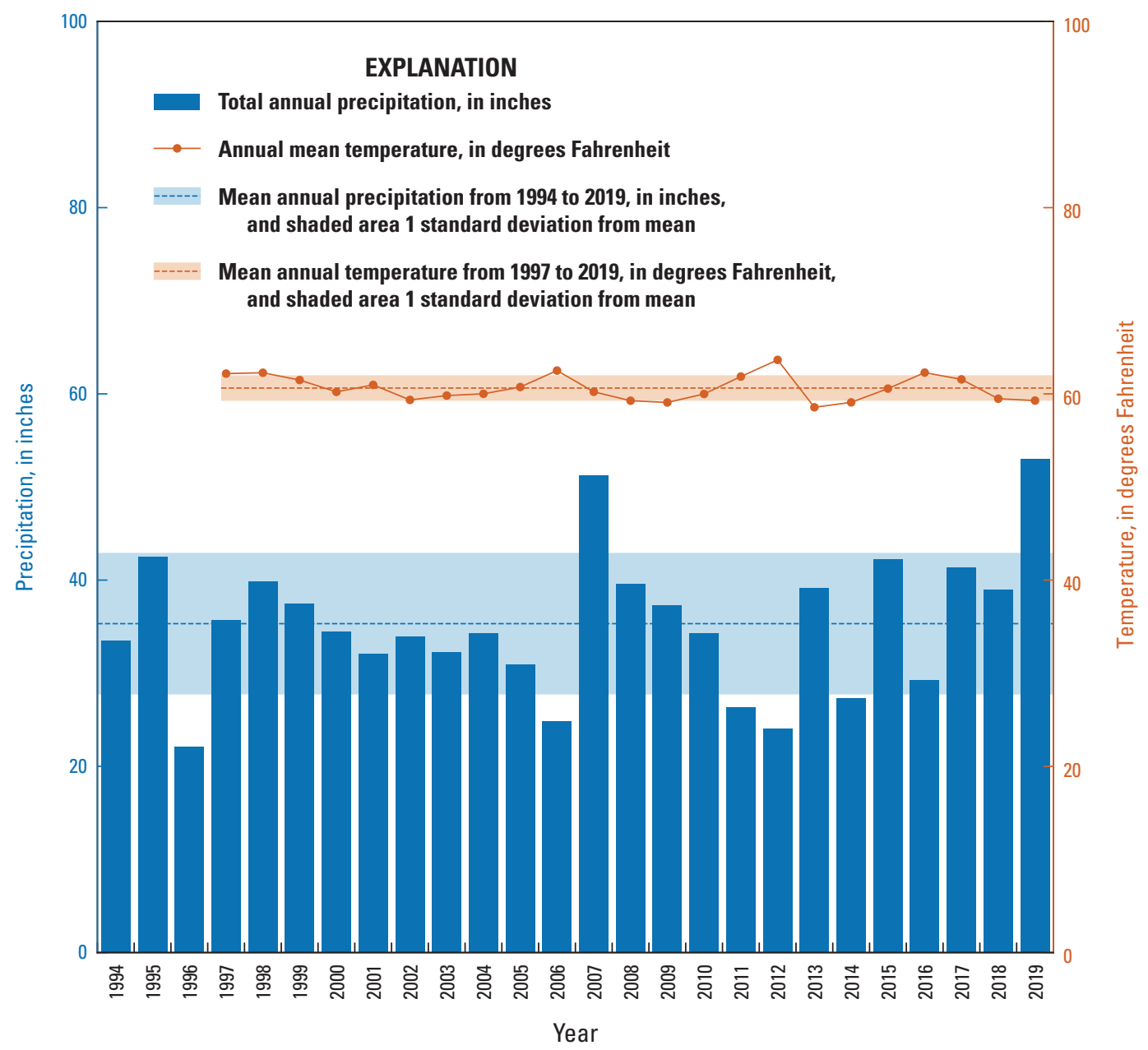

Figure 2. Total annual precipitation and annual mean temperature for each year during the 1994-2019 period of record at the Perkins, Oklahoma, Mesonet weather station (Oklahoma Climatological Survey, 2020) near the study area, the Pawnee Nation subdomain of the overall Cimarron River alluvial aquifer model extent, Payne County, north-central Oklahoma.

\section{Geology}

The geologic units in the Pawnee Nation subdomain include Quaternary-age alluvium and terrace deposits and Permian- and Pennsylvanian-age sedimentary bedrocks (Heran and others, 2003, fig. 6). The surface formations include Upper Pennsylvanian- and lower Permian-age formations overlain by thin Quaternary-age sediments (fig. 6). The surficial geologic units dip gently westward, progressively exposing younger beds in that direction (Shelton and others, 1985). In the area of the current study, unconformities were a common occurrence during the Paleozoic (Shelton and others, 1985). The depositional environment ranged from alluvial to shallow marine (Nakayama, 1955; Greig, 1959; Shelton and others, 1985).

\section{Quaternary Alluvium and Terrace Deposits}

The Quaternary-age deposits consist of alluvium and terrace deposits and dune sand. These deposits unconformably overlie the Permian-age geologic units (fig. 6). The alluvium deposits result from repeated cycles of river erosion and redeposition of detrital sediments (Reed and others, 1952). The terrace deposits are composed of interlayered lenses of clay, sand, and poorly sorted sand and gravel (Shelton and Noble, 1974). These deposits were laid down by the ancestral Cimarron River as it traveled southwesterly down the regional dip of the underlying Permian-age units (Reed and others, 1952). Thicknesses of the terrace deposits range from 0 to 120 feet (ft); variations of thickness occur as a result of erosional features in the underlying Permian-age beds and deposition and erosion of terrace deposits (Reed and others, 1952).

The Cimarron River alluvial aquifer alluvium and terrace deposits range in thickness from 20 to $120 \mathrm{ft}$. The deposits consist primarily of sand, gravel, silt, and clay 


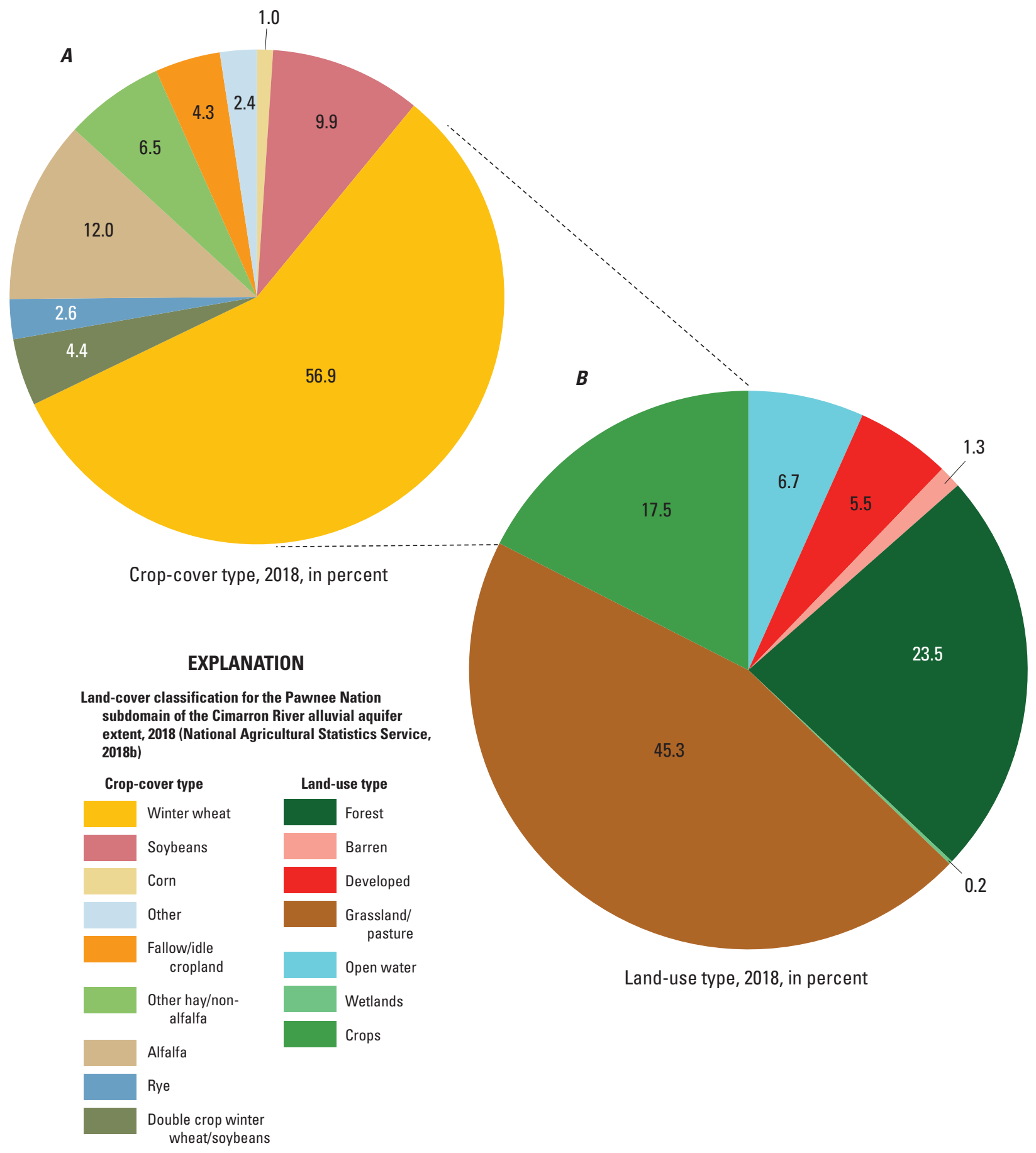

Figure 3. Land-cover classifications for the Pawnee Nation subdomain of the Cimarron River alluvial aquifer model extent, 2018, Pawnee Nation Tribal jurisdictional area, Payne County, north-central Oklahoma. A, Crop-cover type. B, Land-use type.

(Bingham and Bergman, 1980). Occasional sand dunes with large-scale crossbedding are also present on the floodplain along the Cimarron River (Bingham and Bergman, 1980). Where alluvium deposits are exposed along the Cimarron River, sand and gravel with interbeds of clay are usually found in a fining upward sequence (Shelton and others, 1985). The sand is tan to brownish red and characterized by horizontal bedding and small-scale crossbedding (Noble, 1973; Shelton and Noble, 1974). 


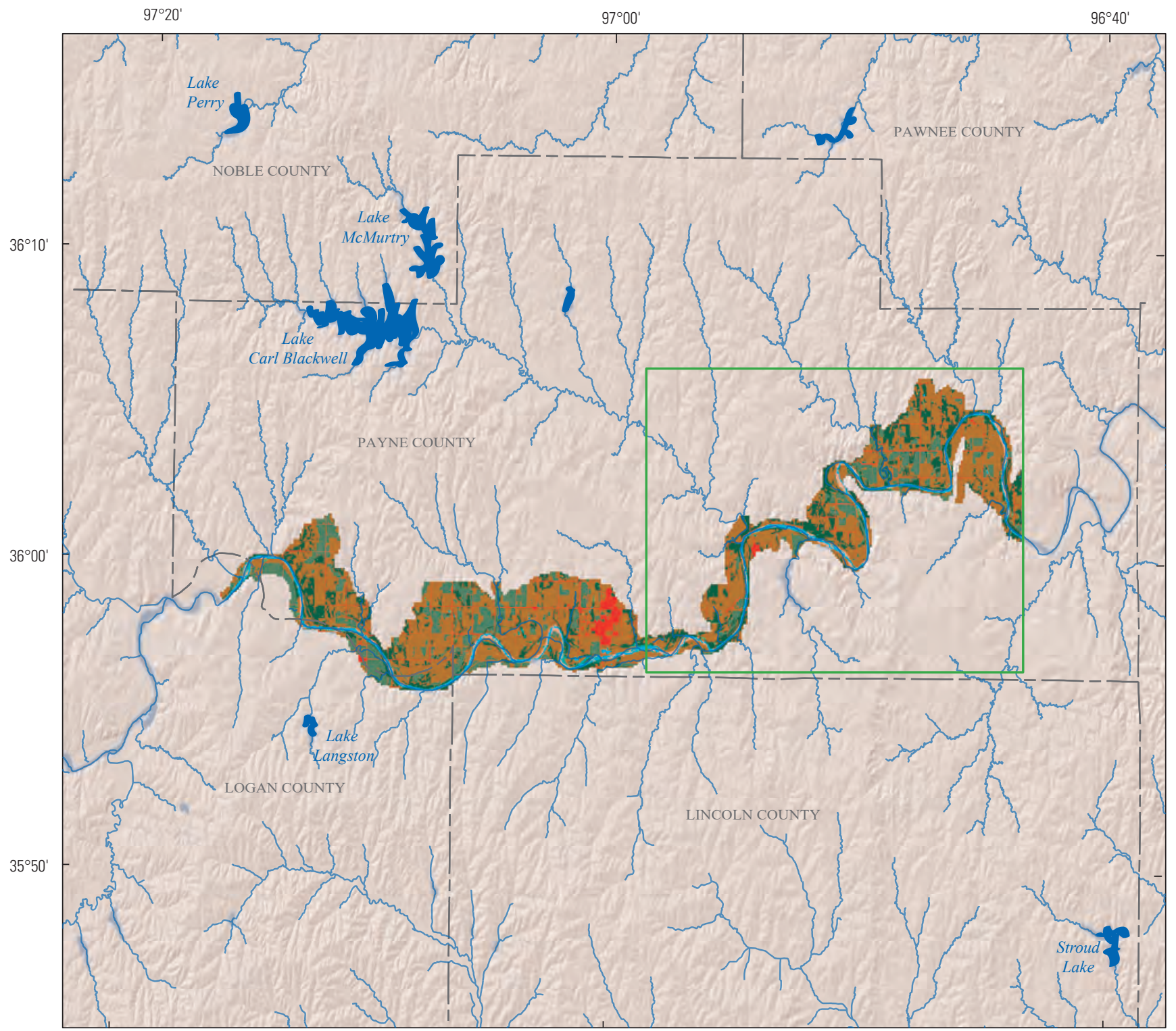

Base from U.S. Geological Survey 1:400,000-scale data (2015) Albers Equal-Area Conic projection North American Datum of 1983

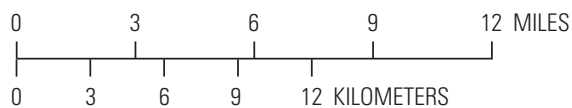

EXPLANATION
Hydrography from Horizon Systems Corporation (2019)

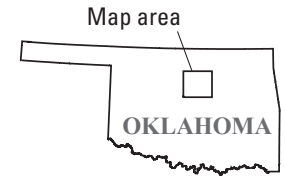

Land-cover classification for the Cimarron River alluvial aquifer extent, 2018 (National Agricultural Statistics Service, 2018b)

\begin{tabular}{|l|l|}
\hline Forest & Open water \\
Barren & Wetlands \\
Developed & Crops \\
Grassland/ & \\
pasture & Pawnee Nation \\
\cline { 2 - 2 } & subdomain \\
\hline
\end{tabular}

Figure 4. Land-cover classification for the Pawnee Nation subdomain of the Cimarron River alluvial aquifer model extent, 2018 (National Agricultural Statistics Service, 2018b). 
Table 2. Estimates of annual groundwater-withdrawal rates for the Cimarron River alluvial aquifer model extent based on one-half of the permitted groundwater-withdrawal rates for well permits, 2016-18.

[Permitted groundwater-withdrawal rates from Oklahoma Water Resources Board (2019a). --, not applicable or unknown]

\begin{tabular}{|c|c|c|c|}
\hline Permit number by permitted use and permitted type & $\begin{array}{l}\text { Permit map identifier } \\
\text { (fig. 5) }\end{array}$ & $\begin{array}{l}\text { Estimated annual } \\
\text { withdrawal rates } \\
\text { for the Cimarron } \\
\text { River alluvial aquifer } \\
\text { model extent, in } \\
\text { acre-feet per year }\end{array}$ & $\begin{array}{c}\text { Estimated annual } \\
\text { withdrawal rates for } \\
\text { the Pawnee Nation } \\
\text { subdomain, in acre- } \\
\text { feet per year }\end{array}$ \\
\hline Irrigation, permanent & -- & 876.0 & 700.0 \\
\hline 19560686 & 3 & 11.5 & -- \\
\hline 19570107 & 4 & 20.0 & -- \\
\hline 19570211 & 5 & 18.0 & -- \\
\hline 19590167 & 6 & 100.0 & 100.0 \\
\hline 19720129 & 10 & 575.0 & 575.0 \\
\hline $19541085 \mathrm{~A}$ & 11 & 53.0 & -- \\
\hline Irrigation, temporary & -- & 567.0 & 14.0 \\
\hline 19780572 & 12 & 179.0 & -- \\
\hline 19900514 & 13 & 14.0 & 14.0 \\
\hline 19910564 & 14 & 65.0 & -- \\
\hline 19930537 & 15 & 169.0 & -- \\
\hline 19930583 & 16 & 140.0 & -- \\
\hline Public supply, permanent & -- & 396.0 & 218.5 \\
\hline 19750762 & 21 & 50.0 & 50.0 \\
\hline 19780536 & 22 & 50.0 & 50.0 \\
\hline 19840607 & 23 & 40.0 & -- \\
\hline 19920525 & 24 & 115.0 & -- \\
\hline 19950599 & 25 & 88.0 & -- \\
\hline Other, permanent & -- & 693.0 & 141.0 \\
\hline 19590150 & 26 & 10.5 & 10.5 \\
\hline 19680328 & 27 & 552.0 & -- \\
\hline 19690142 & 28 & 130.5 & 130.5 \\
\hline Other, temporary & -- & 81.0 & 0.0 \\
\hline 19880503 & 29 & 1.0 & -- \\
\hline 20090503 & 30 & 80.0 & -- \\
\hline Total & -- & 2,956 & 1,174 \\
\hline
\end{tabular}




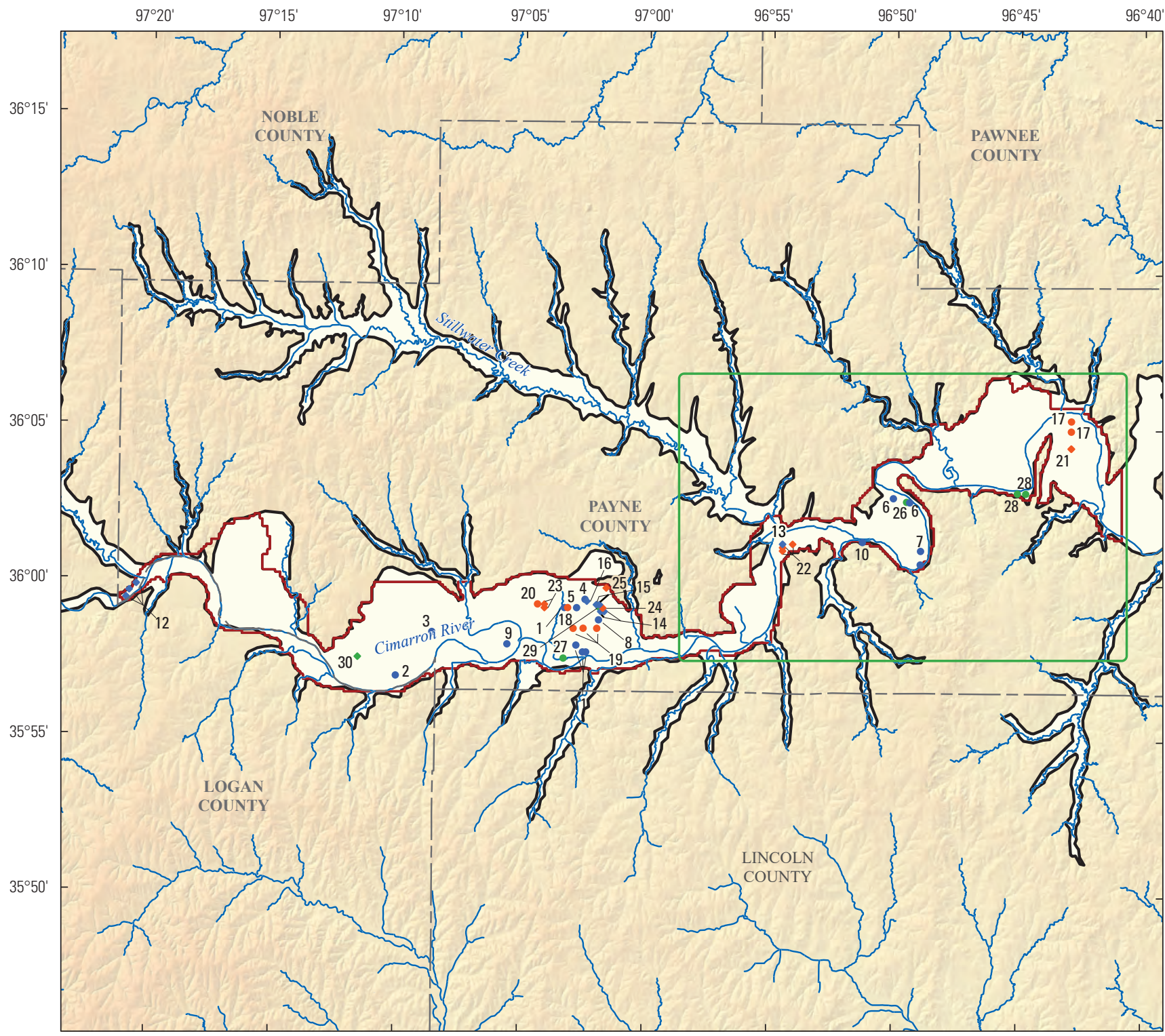

Base from U.S. Geological Survey digital data, 2015 Albers Equal-Area Conic projection North American Datum of 1983

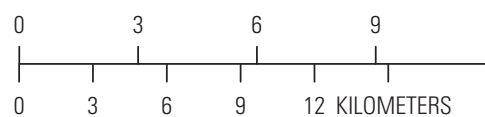

EXPLANATION
Pawnee Nation subdomain area of the overall Cimarron River alluvial aquifer model extent

Cimarron River alluvial aquifer extent

Overall model area for the Cimarron River alluvial aquifer
Groundwater well, by permitted use and permitted type and map identifier (table 2)

- Irrigation, permanent - Other, temporary

- Irrigation, temporary - Production well, permanent

- Other, permanent - Production well, temporary

Figure 5. Locations of wells used for permitted groundwater withdrawals in the model area by permitted use and permitted type (Oklahoma Water Resources Board, 2019a). 


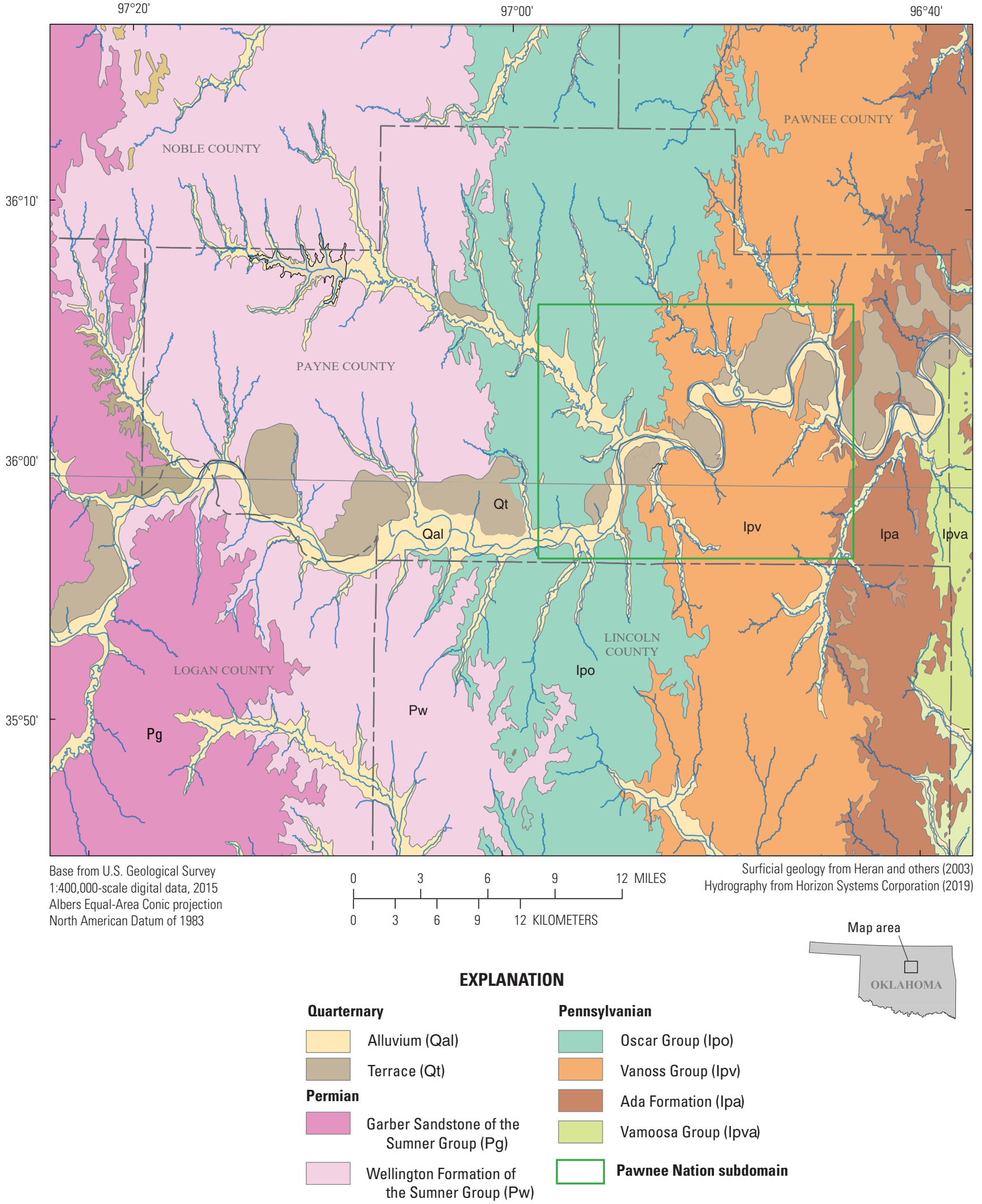

Figure 6. Surficial geologic units of the overall Cimarron River alluvial aquifer model extent. 


\section{Bedrock Units}

Permian- and Pennsylvanian-aged bedrock units underlie the study area. There are two bedrock aquifer units in the area as defined by the OWRB (2019a), the Garber-Wellington aquifer (contained in the Garber Sandstone and Wellington Formation of the Sumner Group [hereinafter referred to respectively as the "Garber Sandstone" and the "Wellington Formation"]) and the Ada-Vamoosa aquifer (contained in the Ada Formation and Vamoosa Group) (fig. 6). Pennsylvanianage rocks outcrop in eastern Payne County, near the Cimarron River; these rock outcrops are overlain by the Permian-aged bedrocks (USGS, 1966).

In the western part of the study area, Permian-age rocks outcrop and underlie the Cimarron River alluvium and terrace deposits. The Garber Sandstone is mostly brownish orange to reddish brown, fine- to medium-grained quartzose sandstone, with a mean thickness of $600 \mathrm{ft}$ (Bingham and Bergman, 1980). The Wellington Formation, the oldest formation of the Sumner Group (Ryder, 1996), consists of sandstone, reddishbrown shale and mudstone, with a mean thickness of $850 \mathrm{ft}$ (Shelton, 1973). Dolomite lenses developed locally in the middle of the Wellington Formation (Logan and others, 1964). The Garber Sandstone and Wellington Formation compose the Garber-Wellington aquifer, a major aquifer in the central part of Oklahoma, but this aquifer is not tapped by large wells in the Cimarron River Basin because of the high percentage of shale. A major groundwater basin (aquifer) is defined by the OWRB (2012) as a distinct underground body of water overlain by contiguous land and having substantially the same geological and hydrological characteristics. The Garber and Wellington Formations dip westward, underlying the alluvial and terrace deposits (fig. 6) (Garden, 1973).

The Oscar Group is of Pennsylvanian age and crops out in the study area from west to east (fig. 6) (Garden, 1973). In the study area, the Oscar Group is composed of red, brown, and gray shale and brownish orange fine-grained cross-bedded sandstone. Arkosic sandstone is present in the southern extent of the Oscar Group. The Oscar Group has a mean thickness of $500 \mathrm{ft}$ (Bingham and Bergman, 1980). The Vanoss Group consists of alternating layers of limestone and shale with fine-grained arkosic sandstone (Shelton and others, 1985). The geologic units that make up the Vanoss Group act as a minimally productive water-bearing unit that yields less than 25 gallons per minute (Garden, 1973). According to the OWRB (2012), a minor aquifer is defined as a distinct underground body of water overlain by contiguous land and having substantially the same geological and hydrological characteristics but containing less water compared to a major aquifer. The Ada Formation underlies the Vanoss Group and consists of shale and lenticular sandstones and thin limestone beds. The fine-grained sandstones in the Ada Group function as a minor aquifer (Garden, 1973). The Vamoosa Formation is the farthest east of all of the rock units that outcrop in the study area and consists of thin to massive layers of fine- to coarsegrained sandstone and sandy silty shale ranging from about
200 to $600 \mathrm{ft}$ thick (Garden, 1973). The Ada-Vamoosa aquifer consists of the Ada Formation and the Vamoosa Formation. In the Pawnee Nation subdomain, the Ada-Vamoosa aquifer dips to the west and has more water-use development potential than any other bedrock-unit aquifer in the study area (USGS, 1966). There are many small towns and industries that pump water from wells that tap the Ada-Vamoosa aquifer; the yield from these wells ranges from 3 to 100 gallons per minute (USGS, 1966).

\section{Hydrogeology}

This section describes the hydrogeology of the Cimarron River alluvial aquifer and the hydrology of the overlying Cimarron River and its tributaries. This information was used to create the conceptual groundwater-flow model for the Cimarron River alluvial aquifer in the Pawnee Nation Tribal jurisdictional area, which in turn provided a means for determining a simplified water budget for the aquifer.

\section{Groundwater}

Groundwater is defined as water in the saturated zone between the water table and the underlying confining unit (Darcy, 1856). Groundwater flows from areas of high hydraulic head to areas of low hydraulic head throughout porous sediment in the Cimarron River alluvial aquifer as described by Darcy's law (Darcy, 1856). Groundwater is introduced into the aquifer (inflows) by recharge from precipitation events, seepage (surface water inflows) from losing reaches of streams, and groundwater lateral flow from the adjacent bedrock aquifers (Domagalski and Johnson, 2012) (fig. 7). A "losing reach" refers to a stream reach where there is likely a net outflow of water from the stream into the underlying groundwater system, whereas a "gaining reach" refers to a stream reach where there is likely a net inflow of water from the groundwater system into the stream (Winter and others, 1998). Outflows of groundwater include groundwater withdrawn by wells, seepage into gaining reaches of streams, lateral flows into the surrounding bedrock, and evapotranspiration (ET) (Lohman and others, 1972) (fig. 7).

Precipitation accounts for most of the recharge to the Cimarron River alluvial aquifer. In general, only a small amount of total precipitation becomes groundwater; before it can infiltrate the alluvial aquifer, most precipitation is lost to ET or surface runoff (Lohman and others, 1972). Groundwater is discharged from the aquifer by seepage into the Cimarron River and its perennial tributaries, meaning that the stream derives part of its streamflow from groundwater and making the Cimarron River a gaining stream throughout most of its extent (Lohman and others, 1972). Groundwater is also discharged from the alluvial aquifer by seepage into the Permianage geologic units underlying it; evidence of seepage into the underlying geologic units has been documented in isolated 


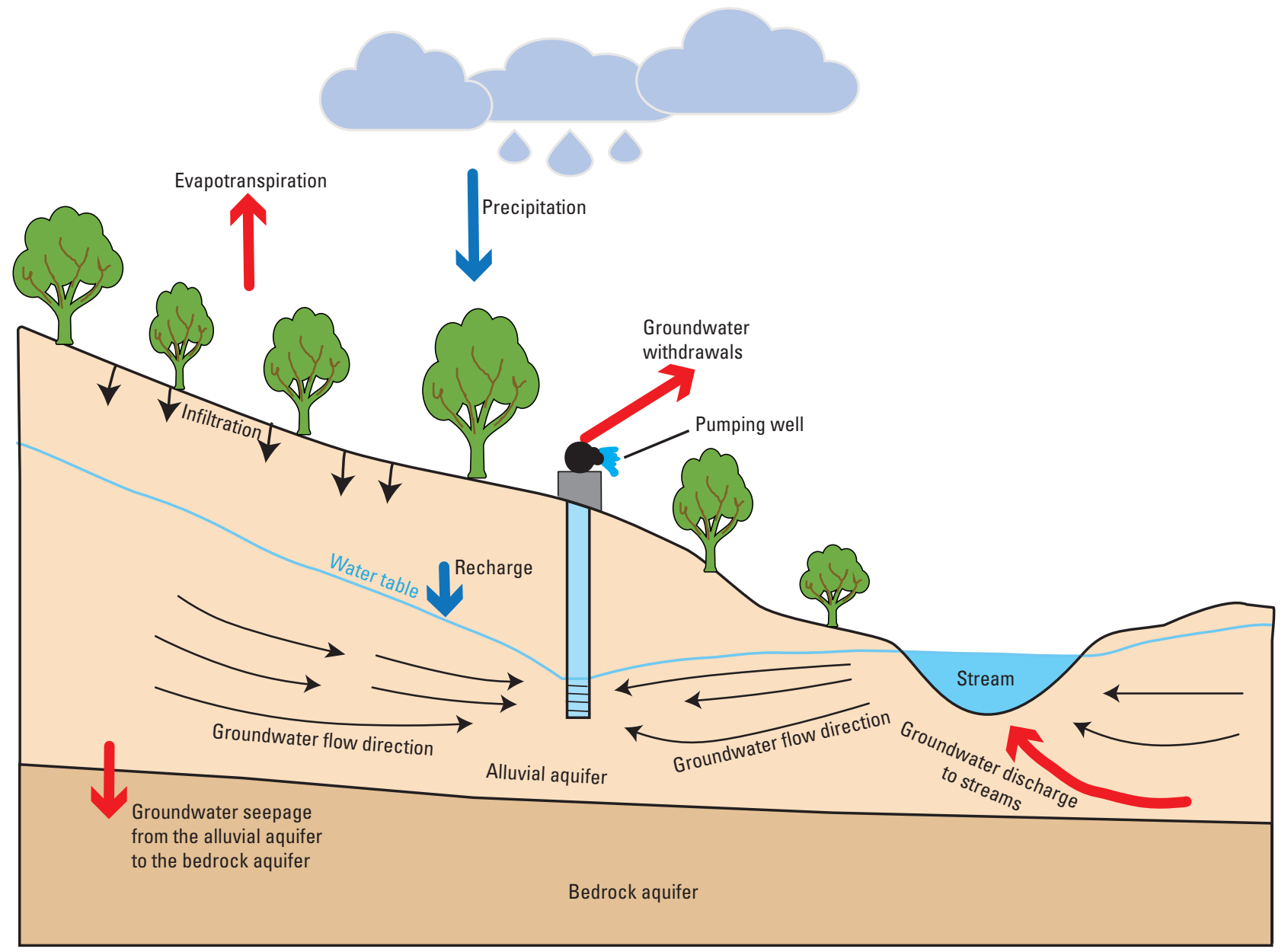

Figure 7. Simplified aquifer schematic indicating inflows (blue arrows), such as precipitation recharge and bedrock lateral flow, and outflows (red arrows), such as evapotranspiration, base-flow contributions to streams, and groundwater withdrawals. Modified from figure 2 in Domagalski and Johnson (2012). Inflow (blue arrows) and outflow (red arrows) are in relation to water movement into or out of the alluvial aquifer, respectively.

areas across the aquifer (fig. 7). The amount of groundwater discharged from the Cimarron River alluvial aquifer to the Permian-age units depends on the hydraulic gradient, the cross-sectional area of flow, and the hydraulic conductivity of the Permian-age units (Adams and Bergman, 1996).

\section{Groundwater Level Fluctuations}

Three groundwater wells completed in the Cimarron River alluvial aquifer were instrumented with Level TROLL 500 vented pressure transducers (In Situ Inc., Fort Collins, Colorado) set to continuously monitor depth to water across the aquifer. Depth to water observations were subsequently converted to water-table altitude observations as described in the "Potentiometric Surface" section of this report. Observations were recorded every 30 minutes during the study period from May 2016 to October 2018 at the following wells completed in alluvium deposits between Yale and Ripley: Cimarron 1 (USGS station number 360429096473901),
Cimarron 2 (USGS station number 360200096534301), and Cimarron 3 (USGS station number 360339096450201 ) (USGS, 2019; Trevisan and Paizis, 2021) (fig. 8). Various hydrologic stressors affect water-table altitudes in an alluvial aquifer, including precipitation, ET, groundwater withdrawal, and streamflow. Hydrologic stressors can cause water-table altitudes to fluctuate on a spatial and temporal basis (Freeze and Cherry, 1979). Similar response patterns were observed at the three instrumented wells in response to precipitation and as a result of groundwater/surface-water interactions. In the data from two of the wells, Cimarron 1 and Cimarron 3, the effects of small earthquakes were evident; the compression and extension of the earthquake resulted in small rises in the depth to water (Oklahoma Geological Survey, 2019) (fig. 8). The "Water-Table Fluctuation Method" section of this report further describes the effects of earthquakes on water-table altitudes. During spring and summer, declining water-table altitudes were primarily associated with seasonally higher 
rates of groundwater withdrawal for agricultural use during the growing season from April through September; ET depletions of groundwater are also highest in spring and summer.

\section{Potentiometric Surface}

In March 2018, synoptic water-table altitude measurements were made at wells throughout the Pawnee Nation subdomain. The wells were constructed with steel casings or slotted polyvinyl chloride with sand backfill on the outside of the well casings. The depth to water below land-surface datum was measured at each well to determine water-table altitudes referenced to the North American Vertical Datum of 1988. Additional water-table altitude measurements were compiled from OWRB well-completion reports, which provided the interval depth at which water was first found during the welldrilling process (OWRB, 2019a). The measured and compiled water-table altitude measurements were used to construct a potentiometric-surface map. The potentiometric surface was then contoured and interpolated by using inverse-distanceweighted interpolation methods in ArcGIS, which will approximate the top of the zone of saturation (Esri, 2011). This inverse-distance-weighted interpolation method breaks up the area into equal cells and estimates the cell values by averaging the values of data points in each processing cell. In the averaging process, the closer a data point is to the center of the cell being estimated, the more influence or "weight" the data point has in the calculation (Esri, 2011). After the interpolation was done with ArcGIS, the contours were then refined by hand and by the use of the digital elevation model (DEM). The DEM was used to obtain elevations at selected points along the stream. Elevation data from the DEM were also used to ensure all contours were below land surface. The potentiometric surface of the Pawnee Nation subdomain was shallow; the mean measured depth to water was less than $29 \mathrm{ft}$ below land surface. Groundwater flows from areas of high potentiometric altitudes to areas of low potentiometric altitudes, at a right

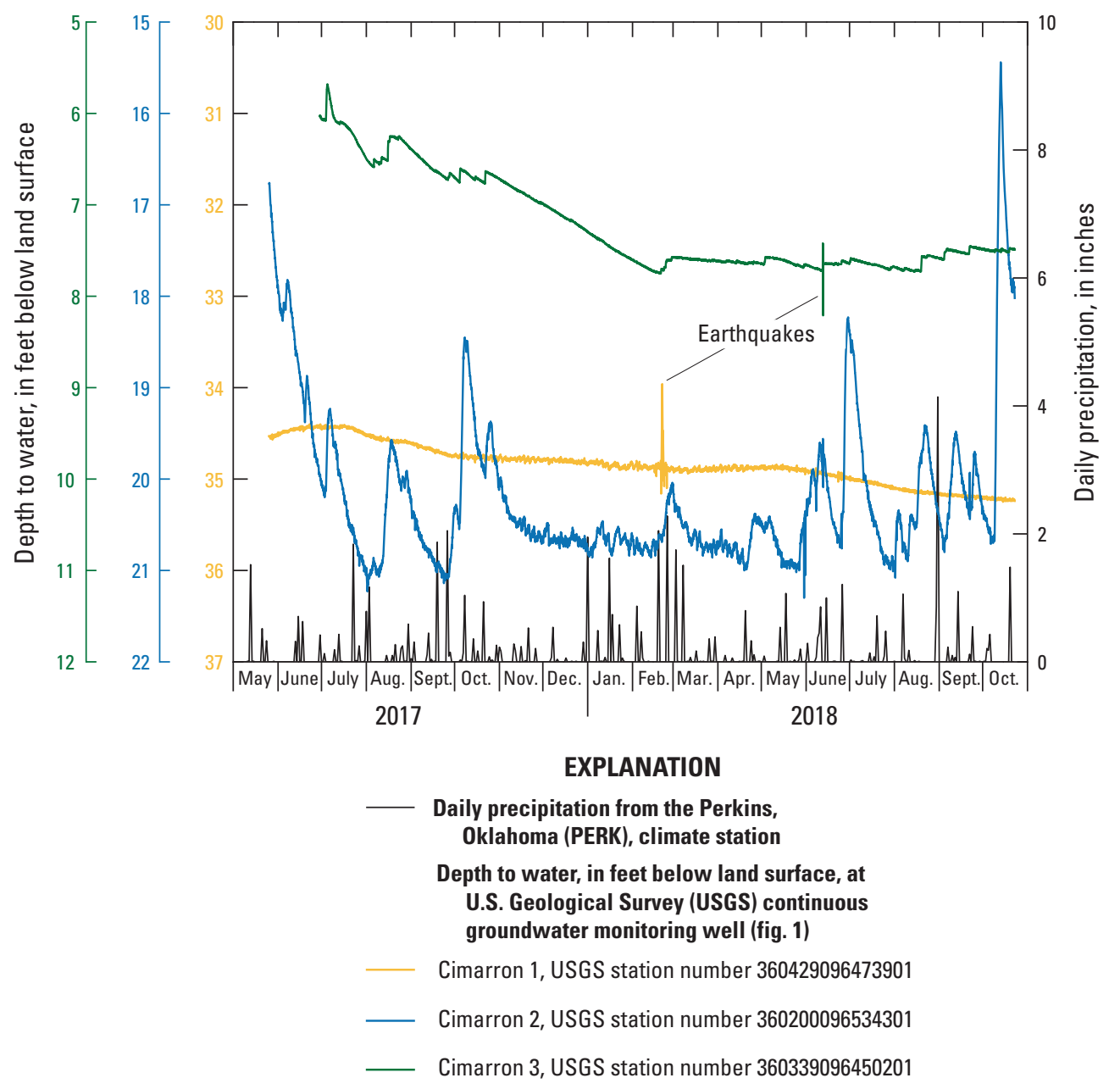

Figure 8. Depth to water at continuous-monitoring wells (U.S. Geological Survey, 2019; Trevisan and Paizis, 2021) and daily precipitation data from the Perkins, Oklahoma (PERK), Mesonet weather station (Oklahoma Climatological Survey, 2020), May 2017 to October 2018, used for the water-table fluctuation method for the use in the model. 
angle to contour lines, allowing the potentiometric contours to be used to infer regional groundwater-flow directions in the aquifer (Freeze and Cherry, 1979). The analysis of the potentiometric-surface map indicated that groundwater in the alluvium generally flows from west to east regionally toward the main river channel at right angles to the direction of streamflow (fig. 9). The Cimarron River is generally a gaining stream, the details of which are described in the "Streamflow" section of this report.

\section{Streamflow}

Data from USGS streamgages on the Cimarron River were assessed to estimate streamflow magnitude, evaluate contributions to streamflow from tributaries and groundwater, and distinguish gaining and losing reaches of the river. There are two USGS streamgages in the Pawnee Nation subdomain (fig. 1). The Ripley streamgage on the Cimarron River in the southernmost part of the Pawnee Nation subdomain recorded a mean monthly streamflow of about 1,140 cubic feet per second $\left(\mathrm{ft}^{3} / \mathrm{s}\right)$ for the study period (USGS, 2019; Trevisan and Paizis, 2021). The Yale streamgage on the Cimarron River in the northernmost part of the Pawnee Nation subdomain recorded a mean monthly streamflow of about $1,320 \mathrm{ft}^{3} / \mathrm{s}$ for the study period (USGS, 2019; Trevisan and Paizis, 2021). The mean monthly streamflow in the Cimarron River for the study period at the Guthrie streamgage was about $830 \mathrm{ft}^{3} / \mathrm{s}$ (fig. 1) (USGS, 2019; Trevisan and Paizis, 2021).

Monthly mean streamflows recorded at the USGS streamgages included in this study are summarized in Trevisan and Paizis (2021) and are fully available in U.S. Geological Survey (2019). Streamflow data were recorded for the study period at all of the streamgages except for the Yale streamgage, which did not begin recording streamflow until September 2016. Streamflow in the eastern part of study area is partially sustained by the groundwater discharge from the Cimarron River alluvial aquifer. In addition to the Cimarron River, the major perennial streams in the study area are Sand Creek, Spring Creek, Stillwater Creek, Deer Creek, Big Creek, Cabin Creek, Council Creek, Salt Creek, and Mud Creek. The amount of streamflow increased between each streamgage in the downstream direction (Trevisan and Paizis, 2021). Over the course of each year during the study period, streamflows typically were highest during April and May and lowest during November and December (fig. 14).

Seepage-run measurements (also known as synoptic streamflow measurements) were made at 10 sites (fig. 1) in March 2018 by using the methods described in Rantz and others (1982). The seepage-run measurements were made during the early spring months, when ET and water use were considered minimal and when the runoff component of streamflow was low. From upstream to downstream, the streamflow generally increases between each site on the Cimarron River (table 3). Inflows from tributaries between sites on the Cimarron River were smaller than the gains in streamflow measured on the main-stem sites, indicating that groundwater inflows likely accounted for much of the increase in streamflow in the downstream direction on the Cimarron River (table 3).

On the Cimarron River from the Ripley streamgage (seepage-run site 1; see table 3 for information about the sites corresponding to all seepage-run site numbers discussed in this section) to the Cimarron River downstream from the confluence with Big Creek (seepage-run site 5), the increase in the streamflow of the Cimarron River most likely is the result of inflow from the underlying Cimarron Pawnee alluvial aquifer model extent. From the Cimarron River downstream from the confluence with Big Creek (seepage-run site 5) to the Cimarron River at the Yale streamgage (seepage-run site 10), the streamflow decreases, indicating that it may be a losing reach of the Cimarron River. During the synoptic measurements of streamflow and water-table altitudes, it was observed that there were numerous large-capacity "lay-flat" hoses and pipes extending inland from the river; these hoses are typically used by industrial entities to pump surface water from the river to the intended-use site. The lay-flat hoses are ideal for industrial use because they are easy to store and transport and lay flat on the ground when not in use, which makes them resistant to movement on uneven terrain and easy to step over. It is not known how recently surface water might have been pumped from the Cimarron River prior to when streamflow was measured as part of the seepage run. Surface-water withdrawal may intensify decreases in streamflow. The streamflows measured as part of this study indicate a general increase in streamflow from upstream to downstream, but surface-water withdrawal may reduce streamflows to the point of mimicking a losing reach.

\section{Recharge}

Recharge is the volume of water that percolates through the vadose zone and reaches the water table. The main drivers of recharge are precipitation, ET, and vadose-zone properties such as permeability and moisture capacity (Freeze and Cherry, 1979). Recharge was estimated by using two methods: the water-table fluctuation (WTF) method (Healy and Cook, 2002) and the Soil-Water-Balance (SWB) code (Westenbroek and others, 2010).

\section{Water-Table Fluctuation Method}

The WTF method was used to provide an estimate of recharge in the Pawnee Nation subdomain. The WTF method assumes that recharge to the aquifer causes short-term, daily to weekly rises in water-table altitudes and that recharge is the main factor causing these rises. This method is best suited for groundwater wells instrumented with continuous recorders that display rapid rises in response to precipitation and those screened in locations with shallow water tables. The WTF 


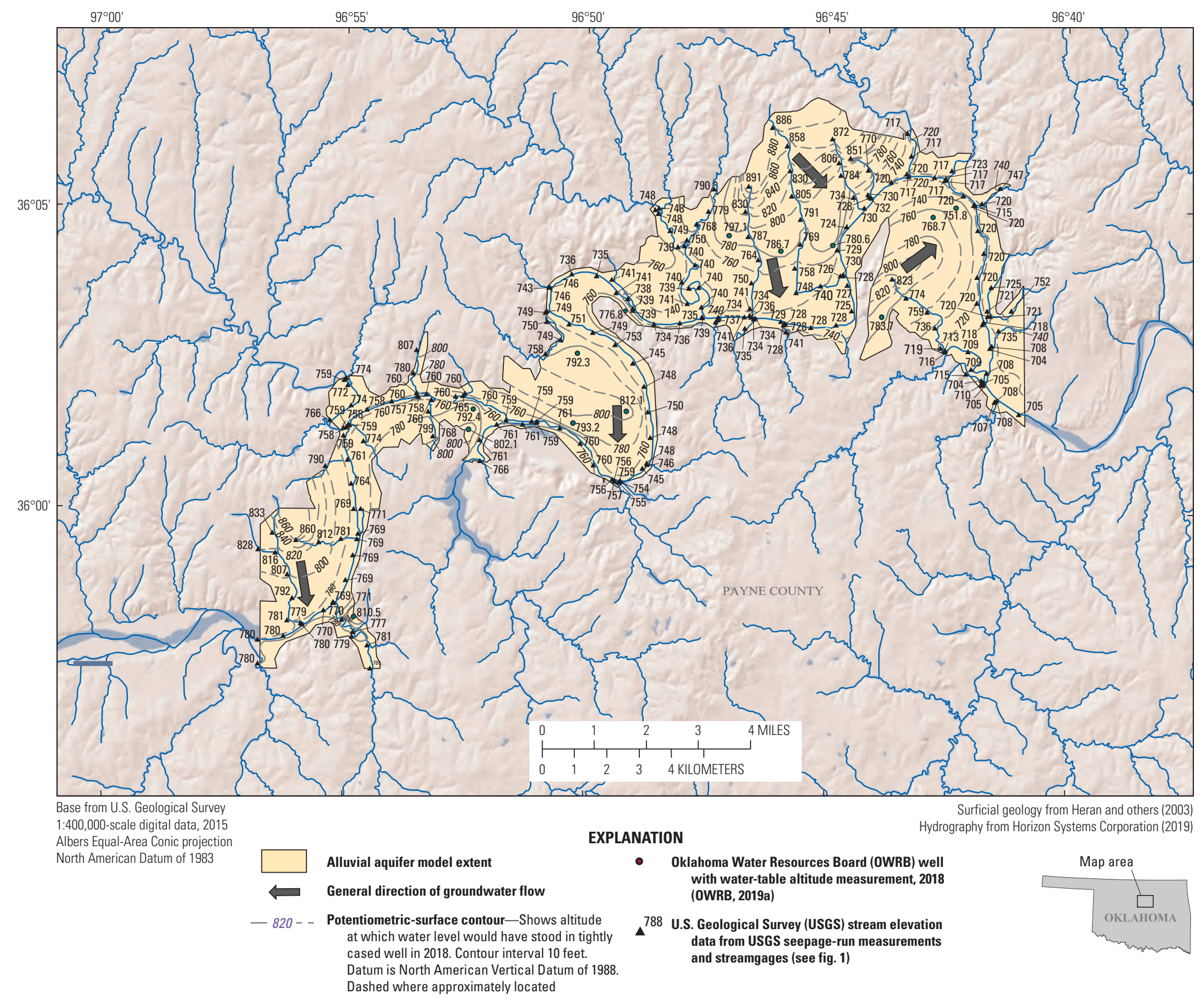

Figure 9. Potentiometric surface of the Cimarron River alluvial aquifer model extent in Payne County, north-central Oklahoma, March 2018. 
Table 3. Seepage-run measurements (also known as synoptic streamflow measurements) in order of upstream to downstream at various sampling locations on the Cimarron River and tributaries in the Pawnee Nation subdomain of the overall Cimarron River alluvial aquifer model extent, Payne County, north-central Oklahoma, March 2018.

[n/a, not applicable]

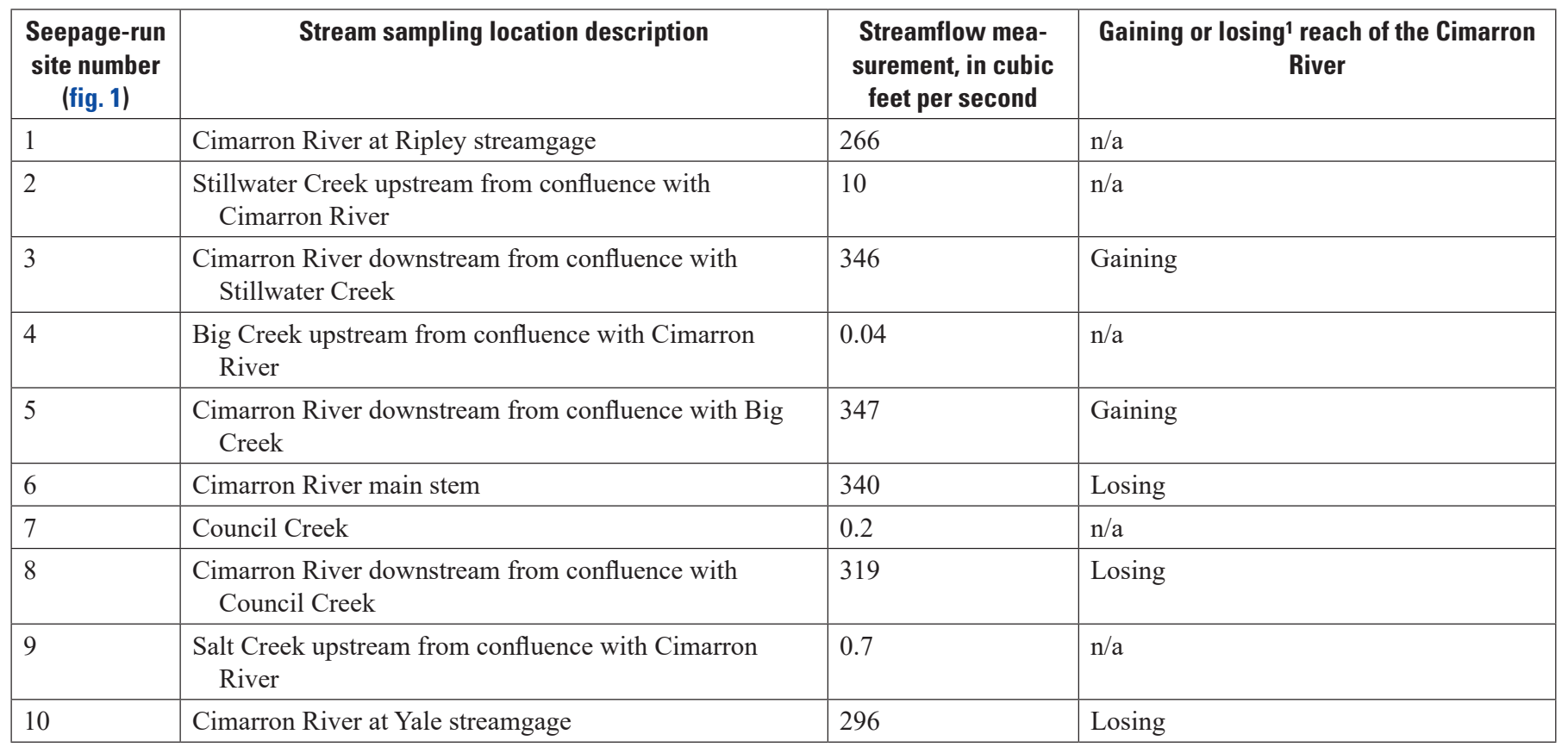

${ }^{1}$ A "losing reach" refers to a reach with a net outflow of water from the stream into the underlying groundwater system, whereas a "gaining reach" refers to a reach with a net inflow of water from the groundwater system into the stream (Winter and others, 1998).

method features the following equation that can be used to compute recharge resulting from water-table altitude rises over a specified time period:

$$
R=S_{y} \Delta h / \Delta t
$$

where

$$
\begin{aligned}
R & \text { is recharge; } \\
S_{y} & \text { is specific yield (dimensionless); } \\
\Delta h & \text { is the change in water-table altitude rise, in } \\
& \text { inches; and } \\
\Delta t & \text { is the change in time, in years. }
\end{aligned}
$$

The WTF method was considered for three USGS continuous-monitoring wells in the Pawnee Nation subdomain (fig. 8) (Trevisan and Paizis, 2021). The Cimarron 1 well (USGS station number 360429096473901) recorded few rises in the water table as indicated by the depth to water measurements from May 2017 to October 2018 (fig. 8). Because the WTF method is contingent upon measuring rises in water-table altitudes from precipitation, the Cimarron 1 well proved unsuitable for estimating recharge with this method. The Cimarron 2 well (USGS station number 360200096534301 ) recorded several large abrupt decreases of $2 \mathrm{ft}$ or more in the depth to water, and one decrease in the depth to water of more than $5 \mathrm{ft}$, but most of these abrupt changes did not correspond to precipitation events or substantial (greater than 1 in.) antecedent precipitation events (fig. 8). For example, the 5-ft decrease in the depth to groundwater occurred during a period with minor (less than 1 in.) antecedent precipitation. Thus, the abrupt changes in groundwater levels at the Cimarron 2 well were likely not related to recharge resulting from precipitation events, and therefore the data from this well were unsuitable for estimating recharge with the WTF method. Of the three continuousmonitoring wells, only the Cimarron 3 well (USGS station number 360339096450201 ) proved suitable for estimating recharge by using the WTF method (fig. 8). By using watertable altitude data obtained from the depth to water measurements recorded at the Cimarron 3 well, recharge was determined to be 9.8 percent of the precipitation that fell from June 29, 2017, to October 23, 2018 (the period when the dataset was most complete). The precipitation recharge percentage for this study ( 9.8 percent) was similar to the precipitation recharge percentage published for other alluvial aquifer studies in Oklahoma (Adams and others, 1997; Ellis and others, 2017; Smith and others, 2017). The 9.8-percent recharge value was multiplied by the 2017 precipitation total (41.4 in.; fig. 2) to estimate a recharge rate of 4.1 inches per year (in/yr) for 2017 (table 4). Adams and others (1997) reported a recharge rate of $2.3 \mathrm{in} / \mathrm{yr}$ in 1996 (8 percent of precipitation) for the part of the Cimarron River alluvial aquifer upgradient from the current 
study area. Although the 8-percent recharge value reported by Adams and others (1997) is similar to the 9.8-percent recharge value derived by the WTF method in this study, the recharge rate of $2.3 \mathrm{in} / \mathrm{yr}$ reported by Adams and others (1997) was only about half of the recharge rate of $4.1 \mathrm{in} / \mathrm{yr}$ estimated for this study (table 4). This difference in recharge rates is likely because the amount of precipitation during 1996 used by Adams and others (1997) was much lower than the 41.4 in. of precipitation during 2017 used in this study (fig. 2; table 1).

Large, abrupt decreases in the depth to water of $0.5 \mathrm{ft}$ within 1 day (corresponding to rises in water-table altitudes of more than $0.5 \mathrm{ft}$ within 1 day) during periods with low or no antecedent precipitation were attributed to earthquakes and excluded for the purpose of determining recharge by the WTF method. In 2017, the Oklahoma Geological Survey (2019) identified more than 300 earthquakes of magnitude 3 or greater. Earthquakes produce oscillatory motion that contracts and expands sediments, thereby causing a sudden rise and fall in water-table altitudes as a result of pressure changes. Alterations to aquifer permeability from the effects of earthquakes can cause non-sinusoidal patterns (signatures) in depth to water measurements and their corresponding water-table altitudes (Roeloffs and others, 2015). Although several earthquakes occurred at about the same time that abrupt changes in water levels were recorded, specific earthquakes could not be linked to these sudden changes at any given well.

\section{Soil-Water-Balance Code}

In addition to the recharge rates estimated by using the WTF method, the SWB code (Westenbroek and others, 2010) was also used to estimate recharge rates spatially and temporally for the Cimarron Pawnee alluvial aquifer model extent. The SWB code requires climatological (precipitation and temperature) and landscape (soil-water storage capacity, hydrologic soil group, land-surface gradient, and land-cover type) characteristics to estimate recharge. The SWB code is used to estimate recharge by applying a modified version of the Thornthwaite-Mather method (Thornthwaite and Mather, 1957).

Various sources were used to compile data for the input files to the SWB code; these input files along with the output files are included in the accompanying data release (Trevisan and Paizis, 2021). Precipitation and temperature data collected at the Perkins, Okla., Mesonet weather station were obtained from the Mesonet database (Oklahoma Climatological Survey, 2020). Soil data were obtained from the CropScape database (National Agricultural Statistics Service, 2018b). Land-surface altitudes and land-surface gradients were derived from a 10-meter land-surface DEM (USGS, 2015).

The SWB code can also be used to compute ET. ET values are estimated spatially and temporally as potential ET. Potential ET was determined by the reference crop ET method (Hargreaves and Samani, 1985), wherein daily maximum and minimum temperature values were used with crop-distribution data to compute ET. Land-use (crop distribution) data were acquired from the National Land Cover Database (NLCD) (Wickham and others, 2014). 
Table 4. Water-table fluctuation method data used to estimate recharge in the Pawnee Nation subdomain of the overall model area for the Cimarron River alluvial aquifer, Payne County, north-central Oklahoma, June 2017 to October 2018.

[USGS, U.S. Geological Survey]

\begin{tabular}{|c|c|c|c|c|c|c|c|c|c|c|}
\hline \multirow[b]{2}{*}{$\begin{array}{l}\text { USGS station } \\
\text { number for } \\
\text { continuous- } \\
\text { monitoring well } \\
\text { (fig.1, table 1) }\end{array}$} & \multirow[b]{2}{*}{$\begin{array}{l}\text { Short name } \\
\text { for monitor- } \\
\text { ing well }\end{array}$} & \multirow[b]{2}{*}{$\begin{array}{l}\text { Mesonet } \\
\text { weather } \\
\text { station } \\
\text { (fig. 1; } \\
\text { table 1) }\end{array}$} & \multirow[b]{2}{*}{$\begin{array}{c}\text { Estimated } \\
\text { specific yield } \\
\text { (dimension- } \\
\text { less) }\end{array}$} & \multicolumn{4}{|c|}{ June 29, 2017, to October 23, 2018} & \multicolumn{3}{|c|}{2017} \\
\hline & & & & $\begin{array}{l}\text { Precipitation, in } \\
\text { inches }^{1}\end{array}$ & $\begin{array}{l}\text { Sum of water- } \\
\text { level rises, in } \\
\text { feet }\end{array}$ & $\begin{array}{l}\text { Recharge, } \\
\text { in inches }\end{array}$ & $\begin{array}{c}\text { Precipitation } \\
\text { portion of } \\
\text { recharge, in } \\
\text { percent }\end{array}$ & $\begin{array}{l}\text { Precipitation, in } \\
\text { inches }\end{array}$ & $\begin{array}{l}\text { Recharge, in } \\
\text { inches }\end{array}$ & $\begin{array}{c}\text { Precipitation } \\
\text { portion of } \\
\text { recharge, in } \\
\text { percent }\end{array}$ \\
\hline 360429096473901 & $\begin{array}{l}\text { Cimarron } 1 \\
\text { well }\end{array}$ & $\begin{array}{l}\text { Perkins } \\
\text { (PERK) }\end{array}$ & 0.10 & 54.0 & 0.6 & 0.1 & 0.1 & 41.4 & 0.1 & 0.1 \\
\hline 360200096534301 & $\begin{array}{l}\text { Cimarron } 2 \\
\text { well }\end{array}$ & $\begin{array}{l}\text { Perkins } \\
\text { (PERK) }\end{array}$ & 0.10 & 54.0 & 19.1 & 22.9 & 42.4 & 41.4 & 17.6 & 42.4 \\
\hline 360339096450201 & $\begin{array}{c}\text { Cimarron } 3 \\
\text { well }\end{array}$ & $\begin{array}{l}\text { Perkins } \\
\text { (PERK) }\end{array}$ & 0.10 & 54.0 & 4.4 & 5.3 & 29.8 & 41.4 & 4.1 & 9.8 \\
\hline
\end{tabular}

${ }^{1}$ Precipitation values measured from the Perkins, Okla., Mesonet weather station (Oklahoma Climatological Survey, 2020).

${ }^{2}$ The 9.8-percent recharge value measured at the Cimarron 3 well from June 29, 2017, to October 23, 2018, was multiplied by the 2017 precipitation total (41.4 inches) to estimate a recharge rate of 4.1 inches per year for 2017. 


\section{Hydrogeologic Framework of the Cimarron River Alluvial Aquifer}

This section of the report describes the hydrogeologic framework of the Cimarron River alluvial aquifer. Aquifer extent is characterized, and aquifer depths were determined using ambient seismic methods and aquifer thicknesses were determined using lithologic logs. Textural and hydraulic properties were estimated using lithologic logs and spatial distribution of lithologies.

\section{Aquifer Extent}

Geological maps of 1:250,000 scale were used to determine the aquifer areal extent (Bingham and Bergman, 1980). As described in the "Description of Study Area" section of this report, the overall Cimarron River alluvial aquifer model extent in the study area covers $98 \mathrm{mi}^{2}$, and $43 \mathrm{mi}^{2}$ of the overall model area is referred to as the "Pawnee Nation subdomain." Aquifer extents throughout the overall model area and in the Pawnee Nation subdomain include only alluvium and terrace deposits (fig. 6), as the bedrock units were not sufficiently hydraulically connected to the alluvium deposits to be included in the model simulations.

\section{Bedrock Altitudes From Ambient Seismic Method}

Hydrogeologic properties of the Cimarron River alluvial aquifer were analyzed by using the horizontal-to-vertical spectral ratio (HVSR) ambient-seismic method (Tromino, 2012) to obtain bedrock altitudes. The bedrock altitudes were verified by using lithologic logs obtained from the OWRB (2019a). The HVSR ambient-seismic method was calibrated at each ambient seismic location (fig. 10).

The ambient-seismic data were collected by a Tromino digital seismometer (MOHO S.R.L., Marghera, Venice, Italy) that gathers ambient-seismic shear waves, thereby measuring the frequency and amplitude of shear waves in three axes, two horizontal and one vertical. The shear-wave velocity of unconsolidated alluvium deposits is about half the shear-wave velocity of consolidated bedrock. The difference in shear-wave velocities in the alluvium deposits and consolidated bedrock causes the horizontal to vertical ratio of the velocities to form a peak from which a measurable resonant frequency of the consolidated bedrock is attained (Tromino, 2012). Bedrock depth is estimated from this resonant frequency according to the following equation from Tromino (2012):

$$
Z=V_{S} /\left(4 F_{0}\right)
$$

where

$$
\begin{gathered}
Z \quad \begin{array}{l}
\text { is the depth to bedrock, in meters (converted } \\
\text { to feet for use in this report); }
\end{array} \\
V_{S} \quad \begin{array}{l}
\text { is the shear-wave velocity of the } \\
\text { unconsolidated alluvium deposits, in } \\
\text { meters per second (converted to feet for } \\
\text { use in this report); and }
\end{array} \\
\begin{array}{l}
\text { is the resonant frequency of the consolidated } \\
\text { bedrock, in hertz. }
\end{array}
\end{gathered}
$$

In September 2018, ambient-seismic data were collected by using the HVSR method at 28 locations and at 1 bedrock control point in the Pawnee Nation subdomain with a known bedrock depth (fig. 10). The bedrock control point was a location where the Oklahoma Department of Transportation drilled a soil test hole, and this hole depth was used as a seismometer calibration point. At each location, the digital seismometer was oriented to geographic north and pushed into a flat area of the ground, allowing the stabilizing spikes on the bottom of the unit to firmly anchor into the soil. The instrument was then leveled and set to record for 16 minutes, a timeframe chosen on the basis of the instrumentation guidelines and the estimated typical thickness of the alluvium deposits (Koller and others, 2004). The ambient-seismic data were analyzed by using Grilla, a software package provided by the digital seismometer manufacturer (Tromino, 2012). The ambient-seismic data collected by using the HVSR method are available in the accompanying data release (Trevisan and Paizis, 2021).

\section{Aquifer Depths and Thicknesses from Lithologic Logs}

Lithologic logs obtained from the OWRB (2019a) were used to construct the alluvium and bedrock surface contact of the Cimarron River alluvial aquifer in areas where the bedrock contact could be determined. Permian bedrock unit terms were used to identify red or consolidated materials such as "red bed," "red or gray shale," "bedrock," and "shale." The bedrock surface was defined at the base of the aquifer by presence of a red sand or shale on an impervious red clay layer adjoining an alluvial sand or gravel. The bedrock contacts were distinguished by analyzing lithologic logs and by using the data obtained from HVSR ambient-seismic method in order to determine the aquifer thickness (fig. 11), which ranged from 20 to $105 \mathrm{ft}$ and averaged about $40 \mathrm{ft}$ (Trevisan and Paizis, 2021). The maximum thickness of the aquifer was in the western part of the Pawnee Nation subdomain. 


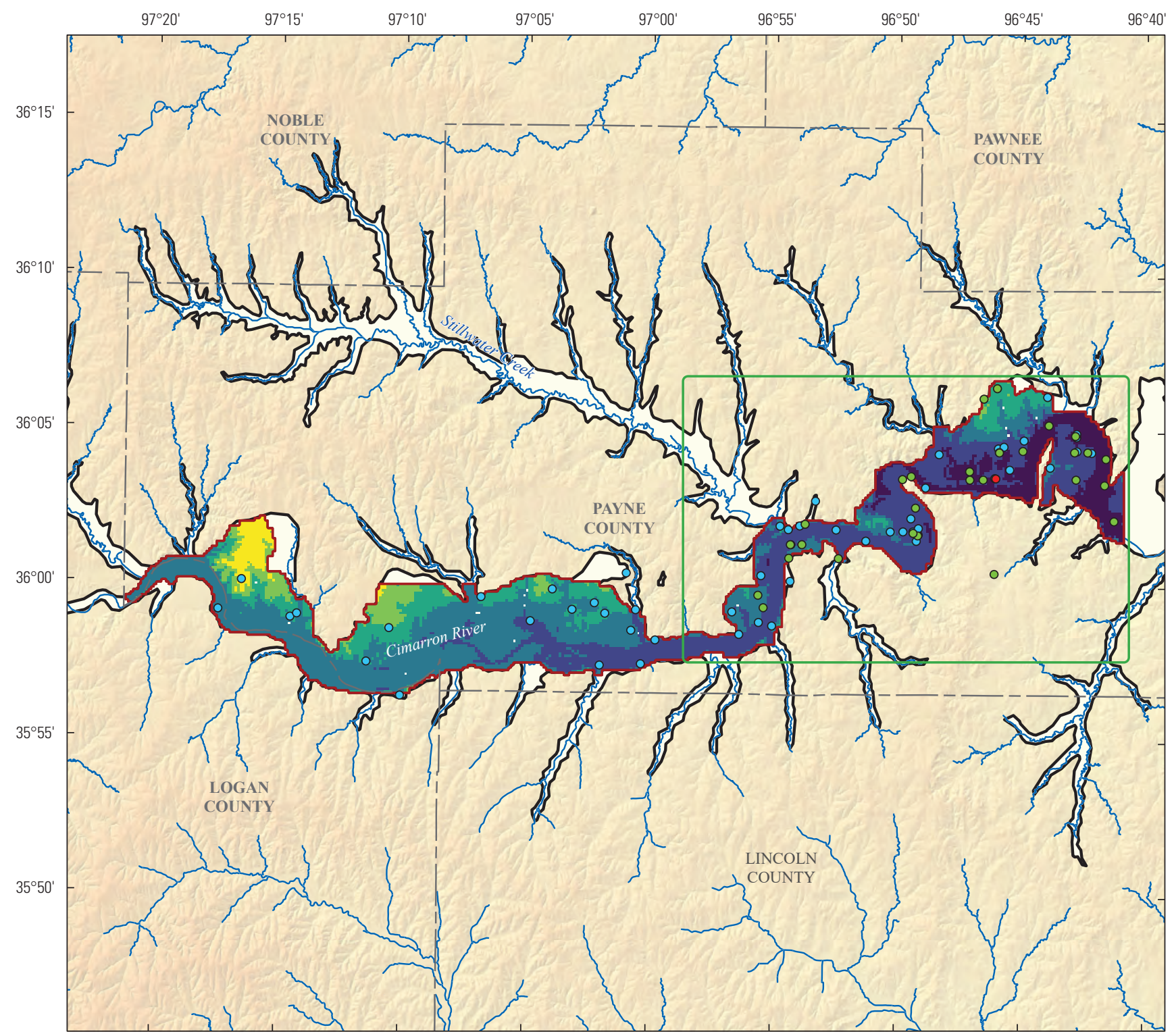

Base from U.S. Geological Survey digital data, 2015 Albers Equal-Area Conic projection North American Datum of 1983

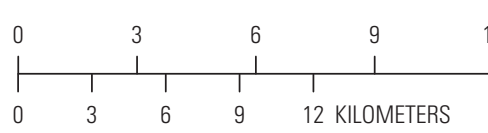

Hydrography from Horizon Systems Corporation (2019) on River alluvial aquifer boundary inferred from alluvium and terrace deposits identified by Heran and others (2003)
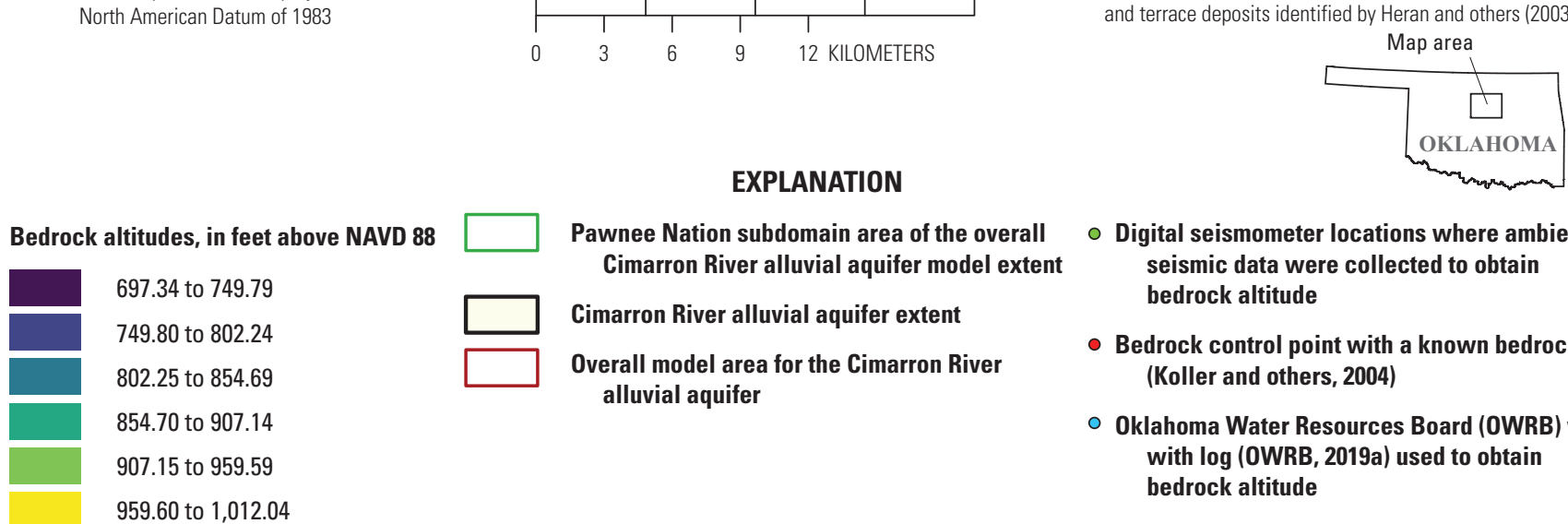

EXPLANATION

Pawnee Nation subdomain area of the overall Cimarron River alluvial aquifer model extent

Cimarron River alluvial aquifer extent

Overall model area for the Cimarron River alluvial aquifer
- Digital seismometer locations where ambientseismic data were collected to obtain bedrock altitude

- Bedrock control point with a known bedrock depth (Koller and others, 2004)

○ Oklahoma Water Resources Board (OWRB) well with $\log$ (OWRB, 2019a) used to obtain bedrock altitude

Figure 10. Bedrock altitudes and ambient seismic locations and Oklahoma Water Resources Board (2019a) well logs used to interpolate the base of the Cimarron River alluvial aquifer. 


\section{Textural and Hydraulic Properties}

This section describes the textural and aquifer hydraulic properties that were estimated by using lithologic logs and spatial distribution of lithologic units to characterize the alluvium and terrace deposits of the Cimarron River alluvial aquifer. The descriptions of lithologic units found in different driller's logs varied among the compiled lithologic logs. The descriptions of lithologic units were standardized and simplified to estimate the percentage of coarse material range of each depth interval.

\section{Lithologic Logs and Percent Coarse Values}

Approximately 950 well-completion reports (well logs of physical characteristics of geologic units observed during drilling, submitted by some well drillers after wells are completed) and 100 lithologic logs associated with these wellcompletion reports were analyzed to characterize the alluvium and terrace deposits of the Cimarron River alluvial aquifer (OWRB, 2019a). The median depth of the lithologic logs is $100 \mathrm{ft}$ below land surface, and most of the lithologic logs penetrated the base of the alluvial aquifer. The construction of the hydrogeologic framework of the aquifer was facilitated by using techniques described in Mashburn and others (2014) to simplify the lithologic descriptions. The different terms on the lithologic logs were classified into the following generalized lithologic categories: clay/silt (less than or equal to 0.0625 millimeter [mm] to $0.125 \mathrm{~mm})$, fine sand $(0.125$ to $0.25 \mathrm{~mm}$ ), medium sand ( 0.25 to $0.50 \mathrm{~mm})$, coarse sand $(0.50$ to $1 \mathrm{~mm})$, very coarse sand ( 1 to $2 \mathrm{~mm}$ ), and fine gravel ( 2 to $4 \mathrm{~mm}$ ) (fig. 12) (Wentworth, 1922; Guy, 1969; Mashburn and others, 2014). The percentage of coarse material value for each lithologic log was then used to estimate and spatially interpolate the hydraulic properties of the Cimarron River alluvial aquifer materials.

\section{Spatial Distribution of Lithologic Categories}

Hydraulic conductivity of the Cimarron River alluvial aquifer was determined by spatially distributing the percentage of coarse material ranges for the compiled lithologic logs. There are many variations in categories of lithologic logs, but they usually contain sand and a clay. Most categories vary widely among each driller's log depending upon the driller doing the drilling analysis. To standardize and simplify the

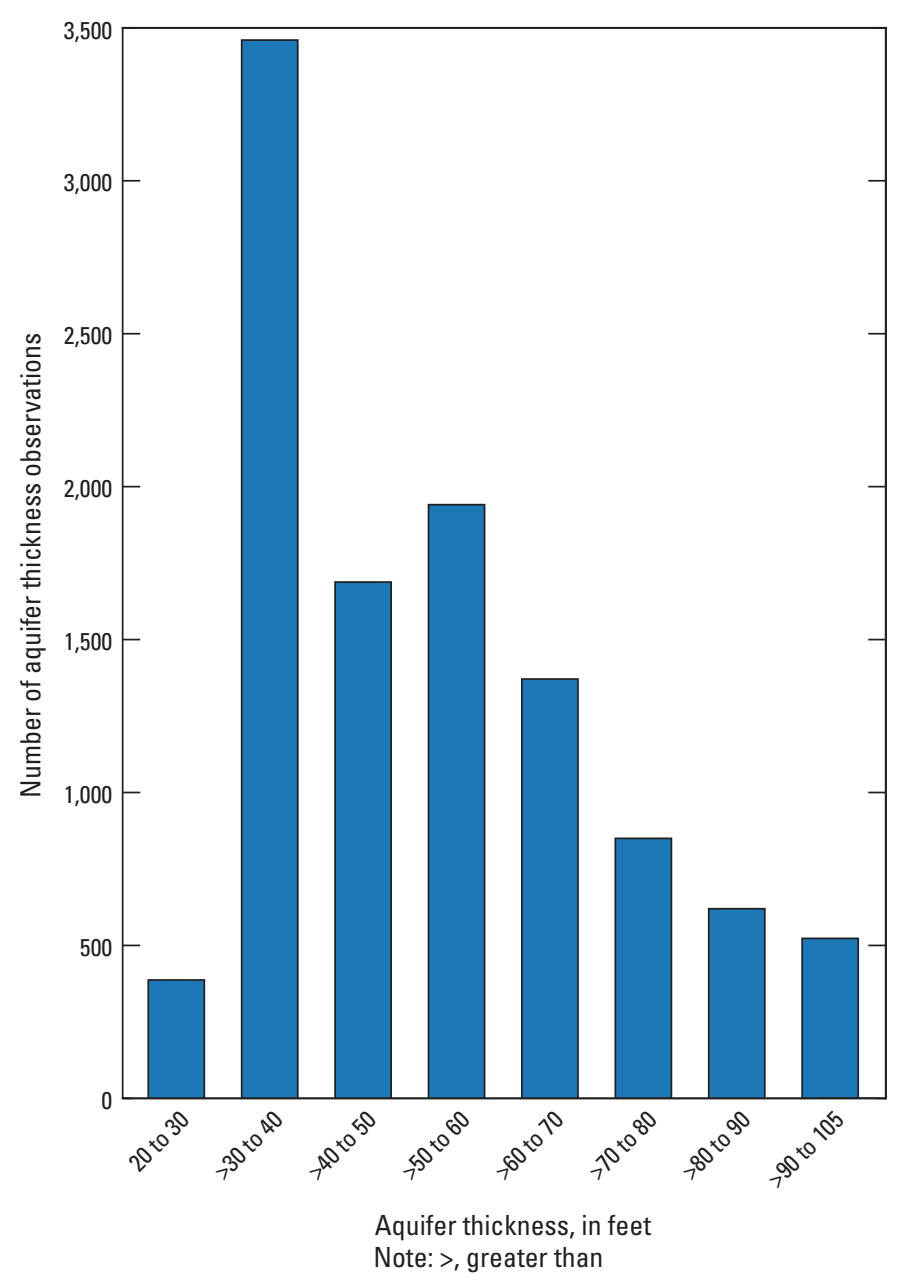

Figure 11. Aquifer thickness observation values determined from lithologic logs. Values were binned with each bin representing approximately 10 feet of saturated aquifer thickness.

lithologic logs, the lithologic descriptions were reclassified into five categories that were used to estimate the percentage of coarse material range of each depth interval. Lithology was categorized into clay/silt, fine sand, medium sand, coarse sand/ very coarse sand, and fine gravel. A percentage of coarse material values based on the midpoint size range of each category was assigned to each lithologic-log depth interval (fig. 12). The percentage of coarse material value for each lithologiclog depth interval was determined as the thickness-weighted mean of percentage of coarse material values assigned to the lithologic categories in each log.

\begin{tabular}{|c|c|c|c|c|c|}
\hline Percent coarse multiplier & 10 & 30 & 50 & 70 & 90 \\
\hline Lithologic category & Clay/silt & Fine sand & Medium sand & Coarse sand/very coarse sand & Fine gravel \\
\hline Size ranges & $\leq 0.0625$ to 0.125 millimeter $(\mathrm{mm})$ & 0.125 to $0.25 \mathrm{~mm}$ & 0.25 to $0.50 \mathrm{~mm}$ & 0.50 to $2 \mathrm{~mm}$ & 2 to $4 \mathrm{~mm}$ \\
\hline
\end{tabular}

Figure 12. Percentage of coarse material multiplier values for the generalized lithologic categories used to obtain horizontal hydraulic conductivity for the Cimarron River alluvial aquifer (Wentworth, 1922; Guy, 1969; Mashburn and others, 2014). 
A percentage of coarse materials range from 0 to 100 percent was assigned, where 0 percent represents silt and clay size material, and 100 percent represents fine gravel size material:

If there was 0-20 percent coarse material, the given section of the lithologic log was classified as clay/silt;

If there was 21-40 percent coarse material, the given section of the lithologic log was classified as fine sand;

If there was 41-60 percent coarse material, the given section of the lithologic log was classified as medium sand;

If there was $61-80$ percent coarse material, the given section of the lithologic log was classified as coarse sand/very coarse sand; and

If there was 81-100 percent coarse material, the given section of the lithologic log was classified as fine gravel.

Horizontal hydraulic conductivity of 0.1 foot per day (ft/d) was assigned to the clay/silt standardized category, and a horizontal conductivity of $100 \mathrm{ft} / \mathrm{d}$ was assigned to the fine gravel standardized category on the basis of the weightedmean horizontal hydraulic conductivity values estimated for each lithologic category (Heath, 1983; Mashburn and others, 2014). This range of categories spans the expected grain sizes in the Cimarron River alluvium and terrace deposits. By assuming that a horizontal hydraulic conductivity of $0.1 \mathrm{ft} / \mathrm{d}$ and a percentage of coarse material multiplier of 10 represent the clay/silt standardized category and that a horizontal hydraulic conductivity of $100 \mathrm{ft} / \mathrm{d}$ and a percentage of coarse material multiplier of 90 represent the fine gravel standardized category, as well as that the relation between the two parameters is linear, the mean horizontal hydraulic conductivity for the aquifer material was calculated by using the following equation modified from Ellis and others (2017):

$$
K_{h}=\left(1.25 \times P_{s}\right)-12.4
$$

where

$$
\begin{aligned}
& K_{h} \quad \begin{array}{l}
\text { is the horizontal hydraulic conductivity, in } \\
\text { feet per day; and }
\end{array} \\
& P_{s} \quad \text { is the percentage of coarse material value. }
\end{aligned}
$$

The frequency distribution of horizontal hydraulic conductivity was determined by using the standardized equation and results are shown in figure 13. The mean horizontal hydraulic conductivity for the Cimarron River alluvial aquifer was estimated as $45 \mathrm{ft} / \mathrm{d}$, the maximum as $141 \mathrm{ft} / \mathrm{d}$, and the minimum as $8 \mathrm{ft} / \mathrm{d}$. These hydraulic conductivities are in the lower part of the range of those published in Adams and Bergman (1996) for a part of the Cimarron River alluvial aquifer farther west of the current study area. Local variations in the percentage of coarse material values of the alluvial aquifer materials may be related to the depositional history and the variability of the lithologic-log descriptions provided by the different well drillers. 


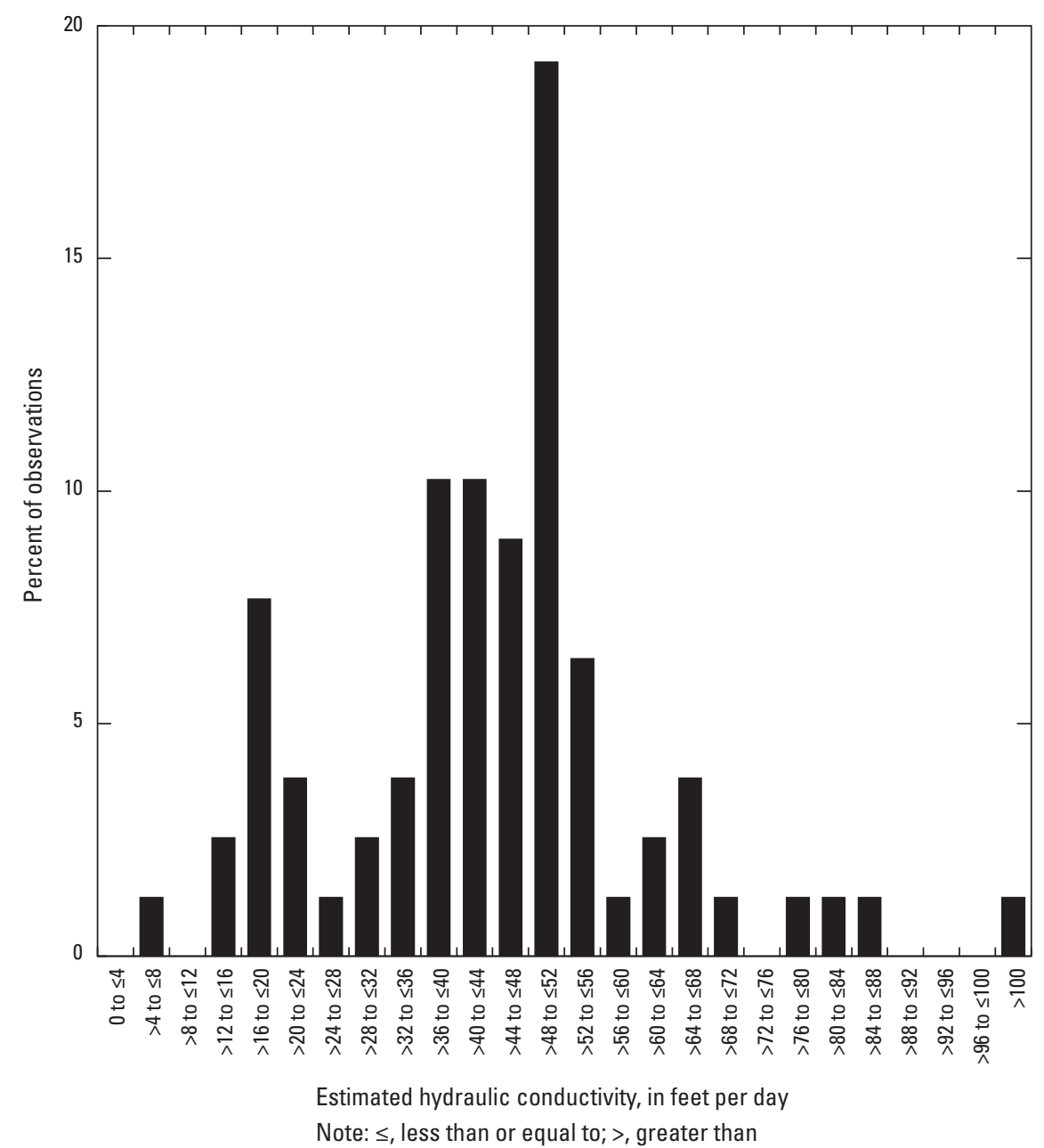

Figure 13. Percentage of observations of estimated horizontal hydraulic conductivity distributions derived from Oklahoma Water Resources Board (2019a) lithologic logs for wells completed in the Cimarron River alluvial aquifer.

\section{Conceptual Groundwater Flow Model and Water Budget}

Mashburn and others (2014, p. 56) describe what a conceptual groundwater-flow model is and how it is used for modeling a groundwater-flow system:

A conceptual groundwater-flow model is a narrative and schematic description of a groundwater-flow system, and an important component of constructing a numerical groundwater-flow model. The conceptual groundwater-flow model describes how the groundwater-flow system is thought to function, and thus contains the framework and components that control [aquifer] storage and flow of groundwater. The two key components of the conceptual groundwater-flow model include the hydrologic boundaries and the water budget. The hydrologic system boundaries are parts of the flow system that interact with groundwater, providing a condition in which water enters or leaves the system. The water budget describes how much of the water in the flow system is accounted for by each of the boundaries.

Hydrologic boundaries are important for achieving a unique solution to a simulation, and include internal and exterior types (Reilly, 2001). Internal hydrologic boundaries include wells, streams (streams also can be external if no appreciable flow moves under the stream), and lakes inside the model domain. Hydrologic boundaries at the lateral or vertical extents are exterior boundaries and can include confining units, faults, or lithofacies changes.

A conceptual groundwater-flow model thus provides a means for determining a simplified water budget for an aquifer. The hydrogeologic framework is accounted for in a conceptual groundwater-flow model (Ellis and others, 2017). Major components of the water budget include groundwater movement between aquifers and groundwater flow into and out of the aquifer through hydrologic boundaries. 


\section{Hydrologic Boundaries of the Cimarron River Alluvial Aquifer}

The most extensive hydrologic boundary of the Cimarron River alluvial aquifer is the land surface. This boundary facilitates recharge to the aquifer and influences ET. The base of the Cimarron River alluvial aquifer influences groundwater flow to the Cimarron River and affects interaquifer groundwater exchange (USGS, 1966). In some locations, lateral flow from other aquifers enters the Cimarron River alluvial aquifer along its boundaries. The Garber-Wellington aquifer contacts the Cimarron River alluvial aquifer along the southern boundary (Mashburn and Magers, 2011; Mashburn and others, 2014). For the Cimarron River alluvial aquifer in the study area, lateral flow also enters the aquifer from the western boundary (hydrologically upgradient) and exits the aquifer from the eastern boundary (hydrologically downgradient).

\section{Conceptual Water Budget}

A conceptual water budget was created to establish estimates of groundwater fluxes into and out of the aquifer through hydrologic boundaries and groundwater withdrawals for use in the numerical groundwater-flow model. The conceptual water budget focuses on the alluvial aquifer, meaning that inflows include sources of water to the aquifer and that outflows include sources of water out of the aquifer such as base-flow contributions to the Cimarron River. The conceptual water budget was constructed using data from 2017 for the Pawnee Nation subdomain.
Recharge from precipitation to the Cimarron River alluvial aquifer is a major source of inflow to the aquifer. Recharge was defined as the amount of water (in acre-feet) from precipitation that reached the water table in a given year. Total precipitation in 2017 was slightly above the mean (fig. 2) but within one standard deviation of the 1994-2019 mean annual precipitation (table 1). Recharge was estimated by using the WTF method (Healy and Cook, 2002). This method assumes that short-term rises in the water table are a result of recharge to an unconfined aquifer. The WTF method incorporated water-table altitude data from June 29, 2017, to October 23, 2018, and as described in the "Recharge" section of this report, the Cimarron 3 well (USGS station number 360339096450201 ) was suitable for use with the WTF method. Recharge was determined to be a large component of the conceptual water budget and the predominant source of inflow to the Cimarron River alluvial aquifer (table 5).

Base-flow values were estimated using the base-flow index (BFI) method (Wahl and Wahl, 1995) from streamflow data collected at the Ripley, Yale, Guthrie, and Lovell streamgages. Stream seepage values were derived from the difference of the mean 2017 base-flow values between the Yale and Ripley streamgages (Trevisan and Paizis, 2021). An estimate of the contribution from nonsimulated tributaries was subtracted from stream seepage estimates because BFI calculation incorporates all tributaries in the catchment for calculating base flows. The final stream seepage was increased by 30 percent because the stream length from the Ripley streamgage to the Yale streamgage covered only 70 percent of the stream (30 percent of the stream was unaccounted) for the Pawnee

Table 5. Conceptual and simulated water-budget totals for the Pawnee Nation subdomain of the Cimarron River alluvial aquifer model extent.

[Simulated values represent the mean of all transient stress periods. Values in the table may be different in the model because of rounding. acre-ft/yr, acre-foot per year; in/yr, inch per year]

\begin{tabular}{|c|c|c|c|c|c|c|c|}
\hline \multirow[b]{2}{*}{ Water-budget category } & \multicolumn{3}{|c|}{ Conceptual water budget } & \multicolumn{4}{|c|}{ Simulated water budget } \\
\hline & acre-ft/yr & in/yr ${ }^{1}$ & $\begin{array}{c}\text { Percent of total } \\
\text { flow }^{2}\end{array}$ & acre-ft/yr & in/yr ${ }^{1}$ & $\begin{array}{l}\text { Percent of total } \\
\text { flow }^{2}\end{array}$ & $\begin{array}{c}\text { Percent } \\
\text { difference }^{3}\end{array}$ \\
\hline Recharge & 9,493 & 4.1 & 100 & 9,661 & 4.1 & 100 & -1.7 \\
\hline Total inflow & 9,493 & 4.1 & 100 & 9,661 & 4.1 & 100 & -1.7 \\
\hline Lateral flow & 1,463 & 0.6 & 15.4 & 1,518 & 0.7 & 15.7 & -3.7 \\
\hline Groundwater withdrawals & 1,304 & 0.6 & 13.7 & 1,303 & 0.6 & 13.5 & +0.1 \\
\hline Evapotranspiration & 985 & 0.4 & 10.4 & 950 & 0.4 & 9.8 & +3.6 \\
\hline Total outflow & 9,493 & 4.1 & 100 & 9,369 & 4.1 & 100 & +1.3 \\
\hline
\end{tabular}

${ }^{1}$ Inches per year based on Pawnee Nation subdomain of 27,784 acres.

${ }^{2}$ Percent of total flow is flow value divided by the sum of input or output flow multiplied by 100 .

${ }^{3}$ Percent difference is calculated as the conceptual value minus the simulated value divided by mean of these two values, with the resulting quotient multiplied by 100 . 
Nation subdomain. Base flows derived using BFI methods (that is, the observed base flows) indicated that the Cimarron River is a gaining stream for the length of the modeled area. Base flows composed the highest percentage of streamflow for periods of low flow (fig. 14).

Groundwater withdrawals were estimated from groundwater-withdrawal rate information that was obtained from the OWRB (2019a) for permanent and temporary permitted wells. One-half of each annual permitted groundwaterwithdrawal rate allotted for a given permit was used as the estimated annual groundwater-withdrawal amount. Halving the permitted groundwater-withdrawal rate was done because permitted withdrawal rates are the maximum permitted rate and actual groundwater withdrawals are generally appreciably less than the maximum permitted rate. Furthermore, using the maximum permitted withdrawal rates caused some cells to rapidly dry and thus reduced the overall withdrawal from the model compared to one-half of the permitted rate. Applying one-half the permitted withdrawal rate allowed consistent groundwater withdrawal through the entire simulation; the groundwater withdrawal rate for the conceptual water budget equaled the simulated groundwater withdrawal rate because
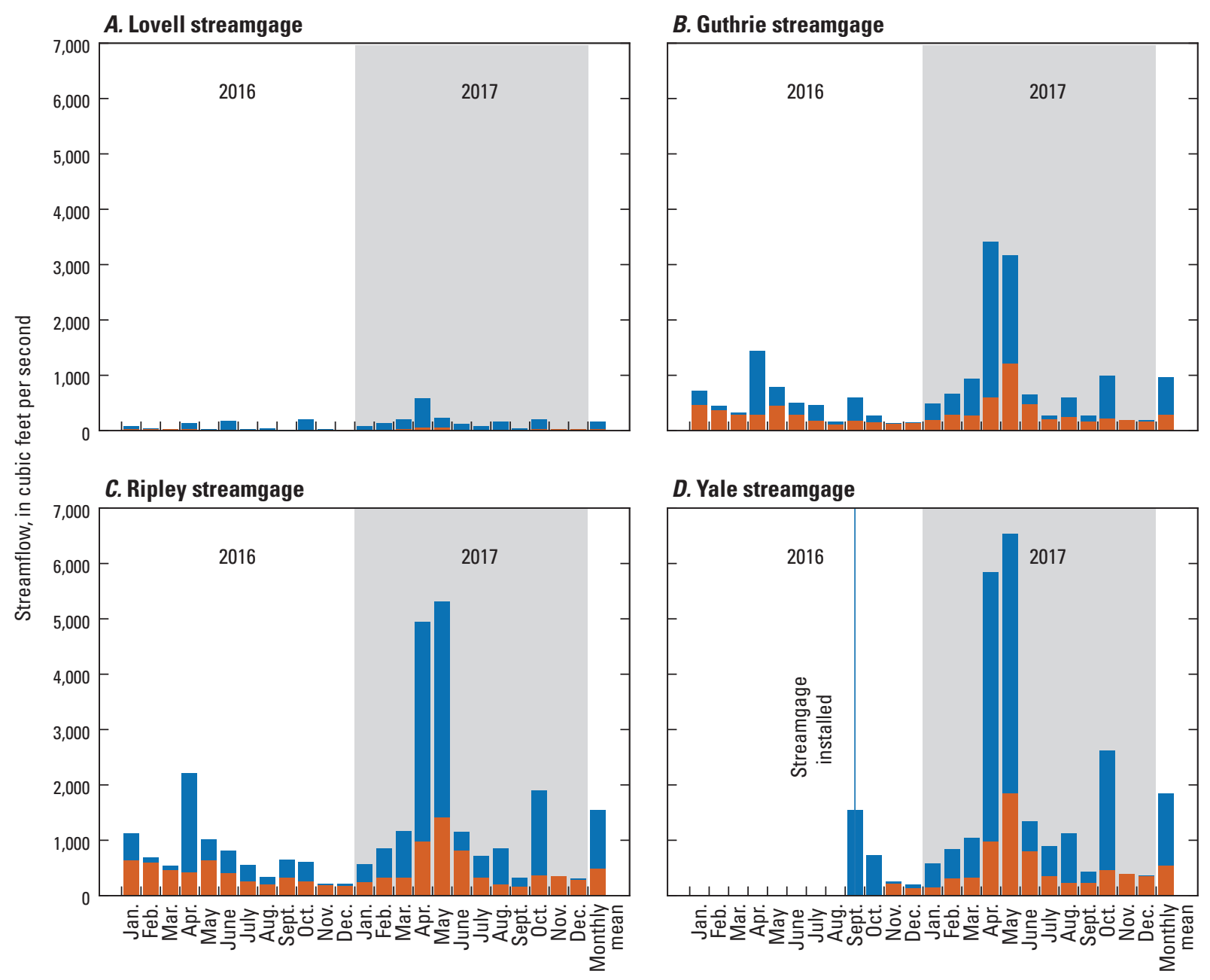

\section{Yale streamgage}

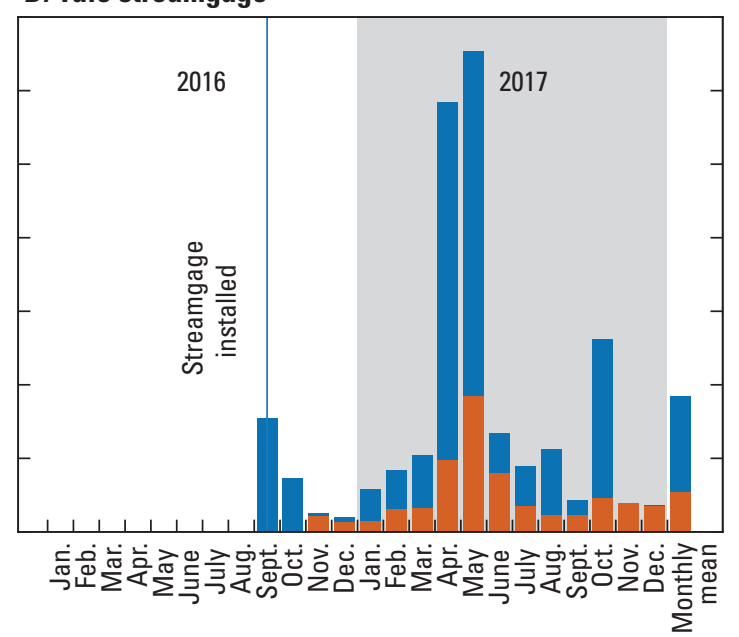

\section{EXPLANATION}

\section{Streamflow}

Base flow

Figure 14. Monthly base flows derived using base-flow index methods (Wahl and Wahl, 1995) for streamflow data collected from 2016 to 2017 for selected U.S. Geological Survey (USGS) streamgages in Payne County, north-central Oklahoma, used for input to the Cimarron River alluvial aquifer model. Mean value represents the mean for 2017 used for the steady-state simulation. A, USGS streamgage 07160500 Skeleton Creek near Lovell, Okla. (Lovell streamgage). $B$, USGS streamgage 07160000 Cimarron River near Guthrie, Okla. (Guthrie streamgage). C, USGS streamgage 07161450 Cimarron River near Ripley, 0kla. (Ripley streamgage). D, USGS streamgage 07163300 Cimarron River near Yale, 0 kla. (Yale streamgage). 
the conceptual water budget and the groundwater withdrawal rate were constructed from the same data (if cells were drying, the simulated groundwater withdrawal amount would be less). Total groundwater withdrawals were estimated as 1,304 acre$\mathrm{ft} / \mathrm{yr}$ for the Pawnee Nation subdomain (table 5).

Wetland areas were identified using the 2006 National Land Cover Database (NLCD) (National Agricultural Statistics Service, 2018b). Wetlands constitute approximately 3 percent of the total area of the Cimarron River alluvial aquifer model extent and 0.2 percent for the Pawnee Nation subdomain. For modeling purposes, different estimates of ET were used for the wetland areas. One estimate was based on the range of ET rates for wetlands documented by White (1932), who measured ET rates ranging from 0.75 to $1.90 \mathrm{ft} / \mathrm{yr}$ for undisturbed salt grass cover for a wetland in southwestern Utah with a mean depth to water of 1-2 ft. An initial ET estimate of $1 \mathrm{ft} / \mathrm{d}$ was applied to wetland areas of the model on the basis of the range of ET rates for wetlands described in White (1932). Additionally, ET derived from the SWB code was used to estimate ET. The SWB code incorporates local land uses and is likely a closer representation of ET than the $1 \mathrm{ft} / \mathrm{d}$ estimate derived from White (1932). Therefore, the ET derived from the SWB code was given higher weighting for estimating ET compared to the estimated ET derived from White (1932).

Lateral flows were identified as inflows along the western model boundary and outflows through the eastern boundary of the model. Additionally, the Garber-Wellington aquifer abuts the southern part of the Cimarron River alluvial aquifer in the model area (Mashburn and Magers, 2011; Mashburn and others, 2014). Flow can enter and exit the Cimarron River alluvial aquifer along this boundary. Lateral-flow constraints (limits governing the minimum, maximum, or exact amount of lateral flow) were unknown. Lateral flow was likely a minimal component of the water budget and was estimated to be about 1,460 acre-ft/yr, which was about 15.4 percent of outflow from the aquifer (table 5).

\section{Numerical Groundwater Flow Model of the Cimarron River Alluvial Aquifer}

MODFLOW-NWT (Niswonger and others, 2011) was used to construct the numerical groundwater-flow model for the Cimarron River alluvial aquifer. The numerical model was developed by using the hydrogeologic framework and the conceptual groundwater-flow model. MODFLOW-NWT is a modified form of the MODFLOW-2005 groundwaterflow model (Harbaugh, 2005) featuring the Newton solver (Niswonger and others, 2011). The Newton solver was used because it improves solving conditions of drying and rewetting model cells within unconfined aquifers such as the Cimarron River alluvial aquifer. A model cell is the smallest subdivision of a finite-difference grid in the MODFLOW model of the aquifer; each model cell has a unique location in the grid, defined by its layer, row, and column indices (Banta, 2014). The model was calibrated to historical water-table altitude observations and base flows derived from continuous streamgage data obtained from the National Water Information System (NWIS) (USGS, 2019). The model was calibrated for a period spanning 2016-17 because few calibration data points were available for 2018. Streamflow-capture analysis was conducted on the model to estimate the effects of hypothetical new groundwater withdrawals on streamflows (base flows) to the Cimarron River.

\section{Model Extents and Configuration}

The Cimarron River alluvial aquifer study area was extended upstream to about 10 miles north of Guthrie (fig. 1). The model domain (identified on fig. 1 as the overall model area for the Cimarron River alluvial aquifer) was defined as such so that additional observation data from outside of the boundaries of the Pawnee Nation subdomain could be included in the calibration process. The conceptual groundwater-flow model and numerical groundwater-flow model scenarios were constructed for the Pawnee Nation subdomain and are documented in the companion data release (Trevisan and Paizis, 2021).

The model domain consists of a single layer representing alluvium and terrace deposits within the Cimarron River alluvial aquifer model area. Modeled land surfaces were derived from a 10-meter DEM (USGS, 2015). Hydrologic sinks were filled in the DEM, and land-surface altitudes were resampled to the groundwater-model grid by using ArcMap (fig. 15) (Esri, 2011). Land-surface altitudes were highest in the terrace deposits (fig. 16). The base of the model is a no-flow boundary, meaning that groundwater cannot flow into or out of the aquifer through the base of the model.

Most of the hydraulic properties were assigned constant values for all active cells; that is, each active cell had identical values for hydraulic properties, except for hydraulic conductivities. Hydraulic conductivities were specified an initial (before calibration) value of $120 \mathrm{ft} / \mathrm{d}$ for the alluvium deposits and $16 \mathrm{ft} / \mathrm{d}$ for the terrace deposits. Vertical anisotropy was assigned an initial value of 2.0, specific storage was set to a constant value of $0.0001 / \mathrm{ft}$, and specific yield was set to 0.10 for the entire model domain (Trevisan and Paizis, 2021). These values were similar to those used in other Oklahoma alluvial aquifer studies (Ellis and others, 2017; Smith and others, 2017).

\section{Discretization}

The model domain consisted of a grid of $500 \mathrm{ft}$ by 500 $\mathrm{ft}$ spacing. Cell size was chosen to appropriately sample hydrologic variations throughout the aquifer while keeping large enough grid sizes to maintain efficient simulation times. The model grid consisted of 340 rows by 724 columns. The 
model domain was adjusted to remove isolated cells from the active area that were not connected to the model. Additionally, 14 cells were removed internally from the model domain because of model convergence issues related to the steep altitude gradients between the alluvium and terrace deposits; 5 of these cells were in the Pawnee Nation subdomain. The model domain consisted of 10,840 cells. In some locations, the model domain was slightly expanded outside of the geologic boundaries to create hydrologic connectivity and drain cells that were previously along the model boundary and would not drain from the model otherwise because these cells were adjacent to a no-flow boundary (the edge of the model extent). The maximum modeled land-surface altitude was approximately $1,100 \mathrm{ft}$, and the minimum modeled land-surface altitude was approximately $755 \mathrm{ft}$ (fig. 15; table 6). Widespread, lowaltitude alluvium deposits are evident on the map of modeled land-surface altitude used in the Cimarron River alluvial aquifer simulation (fig. 15) and reflected in the distribution of modeled land-surface altitudes (fig. 16). Compared to the number of low-altitude alluvium deposits, there were relatively few higher altitude terrace deposits in the model area (fig. 16). Median land-surface altitudes were $837 \mathrm{ft}$ for the alluvium deposits and $899 \mathrm{ft}$ for the terrace deposits (table 6).

The base of the model was interpolated by using the methods described in the "Aquifer Extent" section of this report. Depths were chosen on the basis of the lithologic descriptions of each well. Wells were not used when the well logs had insufficient data to infer a base of aquifer or were too shallow to observe the base of the aquifer. For coincident wells or wells in proximity, the well with the most descriptive well $\log$ was used to represent the aquifer base for the area if the aquifer depth was corroborated by the other well logs. This was done to remove changes in the aquifer base over short distances and reduce interpolation artifacts. Aquifer-base altitudes were estimated by subtracting depths to the base of aquifer from land-surface altitude values derived from the DEM. Base of aquifer altitudes ranged from approximately $697 \mathrm{ft}$ to $1,012 \mathrm{ft}$ (table 6).
In MODFLOW groundwater model simulations, time is divided into discrete intervals called stress periods and time steps. Stress periods represent intervals over which the inflows to and outflows from the aquifer are constant (Ackerman and others, 2010). A steady-state stress period and 24 transient stress periods were used in the model simulations. Monthly stress periods were divided into four equal time steps. The model is run to obtain a water balance of the stream/aquifer exchange for each time step. Data from 2017 were used to establish the steady-state stress period because these 2017 data were within one standard deviation of mean annual values and were the most complete year of record for each data type included in the model (table 1). Transient stress periods represented each month from January 2016 to December 2017. These periods were simulated to better capture seasonal variability. The year 2016 was simulated to establish appropriate transient conditions for the 2017 simulation.

\section{Boundary Conditions of the Numerical Groundwater-Flow Model}

Boundary conditions are areas where water enters into (inflows) or exits from (outflows) the numerical groundwaterflow model. These areas were identified through the hydrogeologic framework and the conceptual water budget. Boundary types were chosen to best represent the boundary conditions while fulfilling the model objectives. Two types of boundaries were used for the model: specified-flux boundaries and headdependent boundaries. Specified-flux boundaries are those that the user defines a volumetric rate into or out of the model at a specific location. Simulation of head-dependent boundaries incorporates the difference between user-defined hydraulic heads at the boundary with simulated hydraulic heads to determine flow. No-flow boundaries were defined along cell edges adjoining inactive cells with no specified boundary.

Table 6. Summary statistics for modeled land-surface altitudes, bedrock altitudes, aquifer thickness, and saturated aquifer thickness for the Cimarron River alluvial aquifer.

[NAVD 88, North American Vertical Datum of 1988; <, less than]

\begin{tabular}{|l|l|l|l|l|l|l|}
\hline \multicolumn{1}{|c|}{ Statistic } & \multicolumn{2}{|c|}{ Modeled land-surface altitude (NAVD 88), in feet } & \multicolumn{1}{c|}{$\begin{array}{c}\text { Model bedrock } \\
\text { altitude (alluvium- } \\
\text { bedrock contact), } \\
\text { in feet }\end{array}$} & $\begin{array}{c}\text { Modeled } \\
\text { aquifer } \\
\text { thickness, } \\
\text { in feet }\end{array}$ & $\begin{array}{c}\text { Calibrated } \\
\text { simulated saturated } \\
\text { aquifer thickness, } \\
\text { in feet }\end{array}$ \\
\hline & \multicolumn{2}{|c|}{ Total } & Alluvium deposits & Terrace deposits & \multicolumn{5}{l|}{} \\
\hline Minimum & 755 & 755 & 755 & 697 & 28 & $<1$ \\
\hline Mean & 871 & 834 & 903 & 817 & 54 & 28.5 \\
\hline Median & 860 & 837 & 899 & 810 & 52 & 30.9 \\
\hline Maximum & 1,100 & 1,007 & 1,100 & 1,012 & 90 & 80.9 \\
\hline Standard deviation & 70 & 40 & 123 & 15 & 16 \\
\hline
\end{tabular}




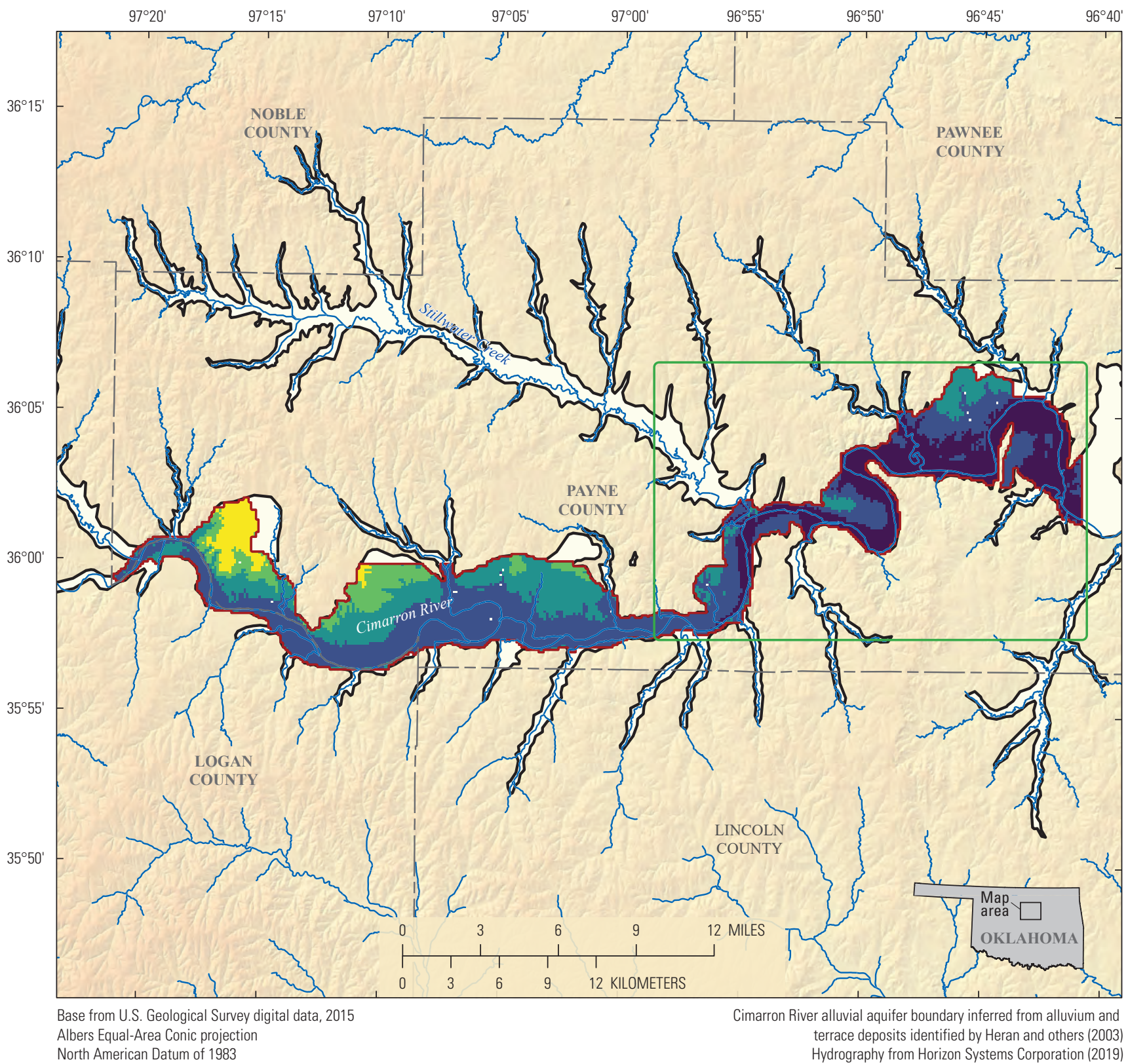

EXPLANATION

Modeled land-surface altitude, in feet above North American Vertical Datum of 1988

754 to less than or equal to 820

Greater than 820 to less than or equal to 890

Greater than 890 to less than or equal to 960

Greater than 960 to less than or equal to 1,030

Greater than 1,030 to less than or equal to 1,100

\section{Pawnee Nation subdomain area of the overall Cimarron River alluvial aquifer model extent}

\section{Cimarron River alluvial aquifer extent}

Overall model area for the Cimarron River alluvial aquifer

Figure 15. Modeled land-surface altitudes used in the Cimarron River alluvial aquifer that were derived from a U.S. Geological Survey digital elevation model (U.S. Geological Survey, 2015). 


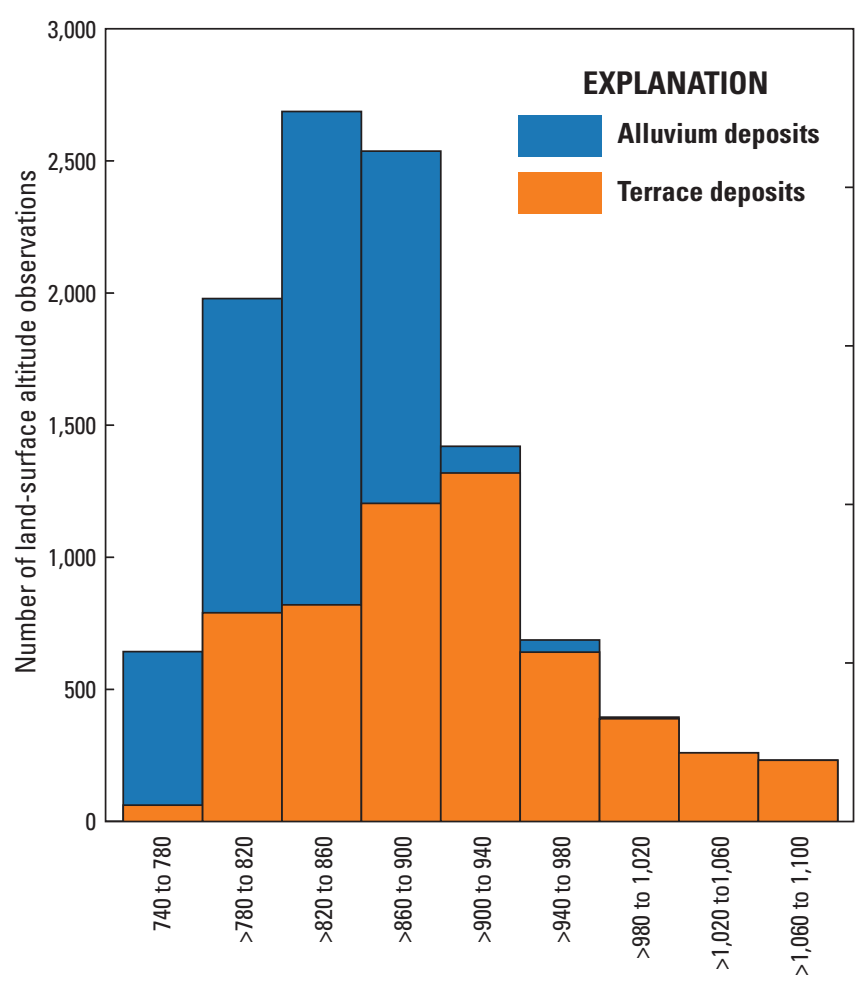

Land-surface altitude, in feet above the North American Vertical Datum of 1988 Note: $>$, greater than

Figure 16. Number of modeled land-surface altitude observations for the Cimarron River alluvial aquifer model using 10 bins. Land-surface altitudes were derived from a U.S. Geological Survey digital elevation model (U.S. Geological Survey, 2015).

\section{Groundwater Recharge}

The Recharge package for MODFLOW groundwaterflow models (Harbaugh, 2005) was used to apply distributed recharge to the model by using a specified-flux condition. Mean recharge rates for 2017 were estimated using SWB code to determine recharge totals for the steady-state stress period. Monthly recharge totals were used for each corresponding month of the transient stress periods. Multipliers for each recharge array (SWB code-derived) were adjusted in calibration to align with gross recharge for the conceptual model (WTF method-derived) and to match base flows for each streamgage. Mean recharge rates varied from 0.0 to 7.5 in/yr (fig. 17). The amount of recharge to the Cimarron River alluvial aquifer was generally higher in the alluvium deposits near the Cimarron River than in the alluvium deposits farther from the river (fig. 17).

\section{Water-Table Evapotranspiration}

The Evapotranspiration package for MODFLOW groundwater-flow models (Harbaugh, 2005) was used to simulate water-table ET processes not simulated using SWB code but instead using a head-dependent boundary condition. The SWB code only considers ET from vegetation on the basis of soil moisture availability. The water-table extinction depth was set to the SWB code root-zone depth for each land-cover type. The extinction depth is the depth at which ET processes terminate. Water-table ET decreases linearly to the extinction depth and terminates at that depth (Harbaugh, 2005). Watertable ET was limited to alluvium deposits, where water-table altitudes were near surface, and ET rates were adjusted during model calibration.

The ET and recharge arrays derived from the SWB code were implemented into the model. Values of zero recharge were replaced with the mean value for each recharge array. Mean values from the ET and recharge arrays for 2017 were used in the steady-state model. For the transient stress periods, the corresponding monthly arrays for recharge and ET were used for each corresponding stress period.

\section{Streamflow}

The Streamflow-Routing (SFR) package (version 2) for MODFLOW groundwater-flow models (Niswonger and others, 2011) was used to simulate flow for the Cimarron River and a small part of Stillwater Creek (fig. 18). The SFR package routes flow downstream and determines streambed seepage (aquifer-stream exchange) through Darcy's law calculations by using streambed hydraulic conductivity and the hydraulic gradient between the stream and the aquifer. Streambed hydraulic conductivity is defined as the hydraulic conductivity of the streambed multiplied by the area of the streambed in contact with the aquifer per unit of streambed thickness. Manning's equation (Chow, 1959) is used to compute stream stage for SFR purposes. Stream-seepage flows between surface water and groundwater are determined by the hydraulic gradient between stream stage and water-table altitudes, such that flow moves from higher altitudes to lower altitudes.

A stream-water balance estimates water availability for stream/aquifer exchange. Inflows in the water balance include water routed from upstream and (or) tributaries, specified inflow points, and gains from the aquifer. Outflows include diversions, direct evaporation, and losses to the aquifer. Streamflows are estimated along reaches (the part of the stream in a model cell) until the end of a segment (group of cells with uniform or linearly variable hydraulic properties) for each time step (Harbaugh and others, 2000; Hill and others, 2000). Calculation of flows downstream incorporates flows from upgradient and adjacent reach inflows (tributaries). In this way, water is routed downstream through the model to the terminal SFR boundary cell.

Stream extents were derived from the National Hydrography Dataset Plus (NHDPlus) (Horizon Systems Corporation, 2019) and were slightly modified to ensure that simulated land-surface altitudes decreased downstream. Tributaries were not simulated, except for a small reach of Stillwater Creek that begins at SFR inflow 2, one of the two 


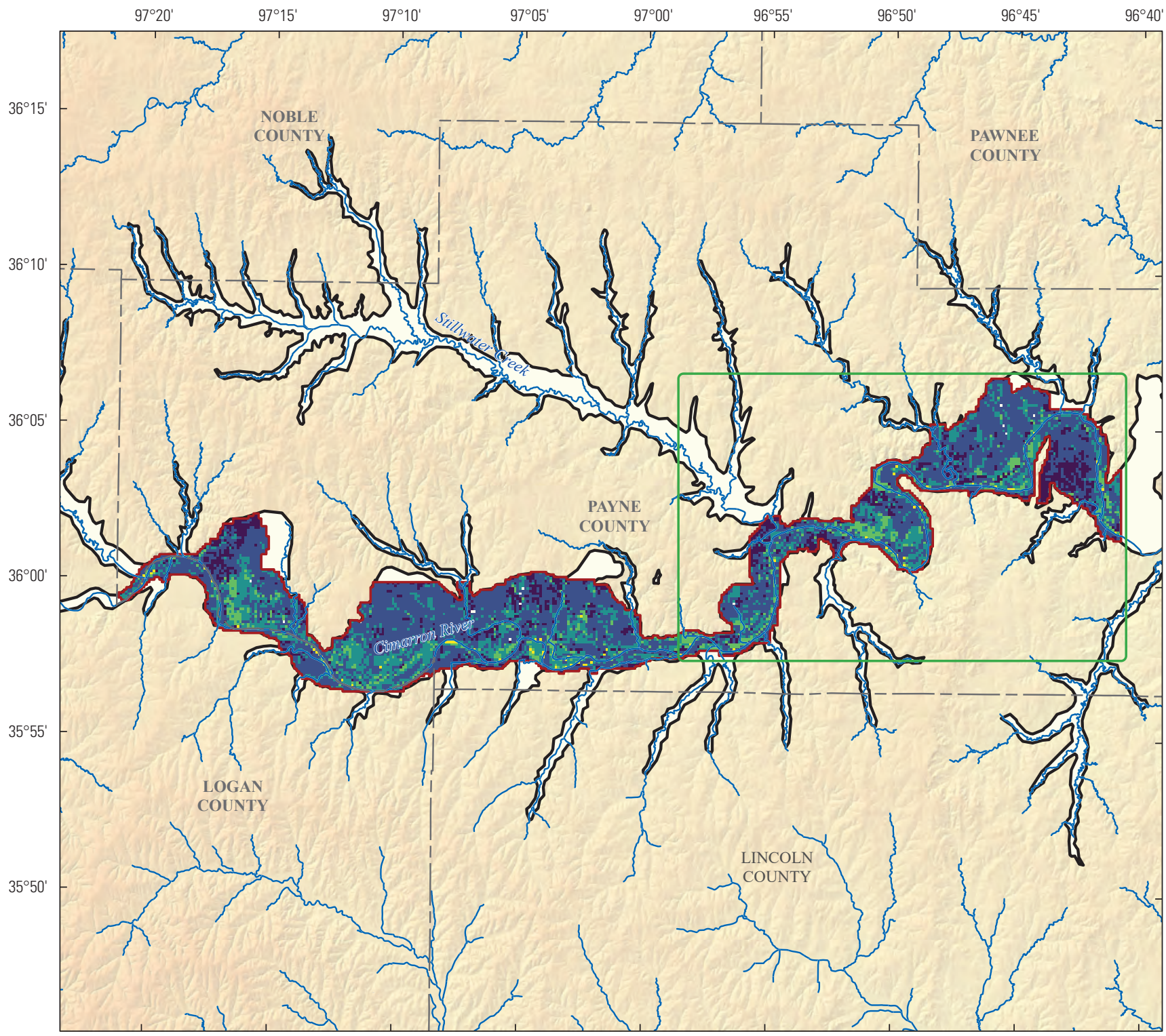

Base from U.S. Geological Survey digital data, 2015 Albers Equal-Area Conic projection North American Datum of 1983

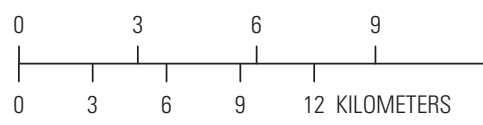

Hydrography from Horizon Systems Corporation (2019) Cimarron River alluvial aquifer boundary inferred from alluvium
and terrace deposits identified by Heran and others (2003)

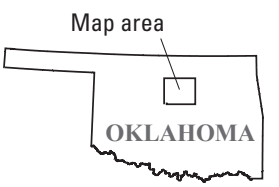

Mean recharge during 2016-17, in inches per year

0.0 to less than or equal to 1.5

Greater than 1.5 to less than or equal to 3.0

Greater than 3.0 to less than or equal to 4.5

Greater than 4.5 to less than or equal to 6.0

Greater than 6.0 to less than or equal to 7.5

EXPLANATION

Pawnee Nation subdomain area of the overall Cimarron River alluvial aquifer model extent

\section{Cimarron River alluvial aquifer extent}

Overall model area for the Cimarron River alluvial aquifer

Figure 17. Mean recharge during 2016-17 used for the Cimarron River alluvial aquifer steady-state simulation. 

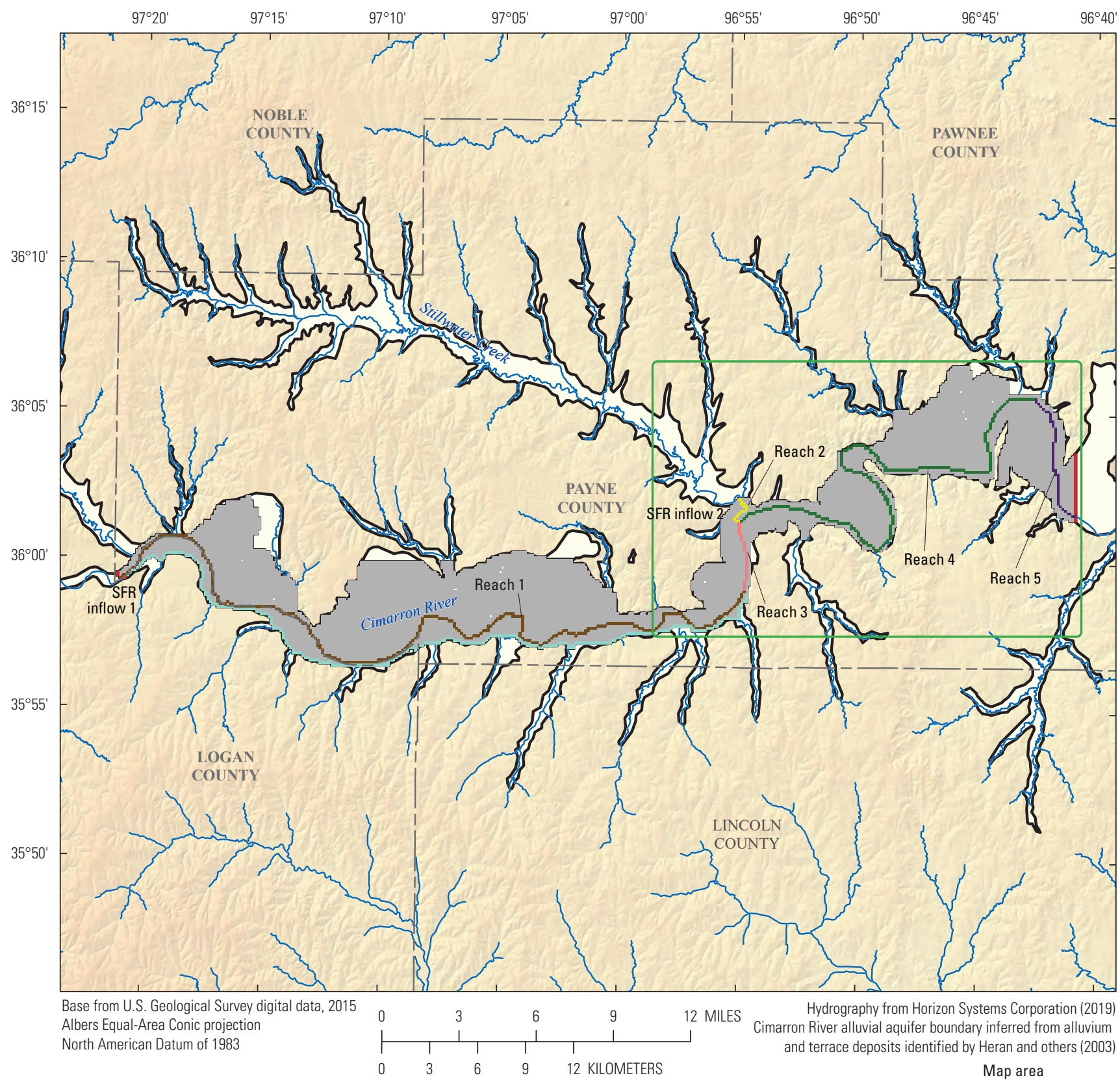

12 MILES Hydrography from Horizon Systems Corporation (2019) Cimarron River alluvial aquifer boundary inferred from alluvium Albers Equal-Area Conic projection North American Datum of 1983

\section{EXPLANATION}

\begin{tabular}{l}
\hline $\begin{array}{c}\text { Pawnee Nation subdomain area of the overall } \\
\text { Cimarron River alluvial aquifer model extent }\end{array}$ \\
Cimarron River alluvial aquifer extent \\
Cimarron River alluvial aquifer model boundaries \\
Active model area \\
General head boundary \\
General head boundary, representing inflow \\
from the Central Oklahoma aquifer (locally \\
known as Garber-Wellington aquifer)
\end{tabular}

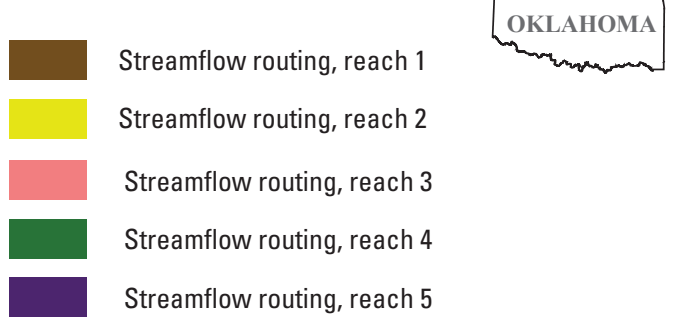

Map area

Figure 18. Model boundary conditions, stream reaches, and inflow points for the Streamflow-Routing (SFR) package (Niswonger and others, 2011) for the Cimarron River alluvial aquifer simulation. 
SFR inflows along with SFR inflow 1 at the western boundary of the model (fig. 18). Stillwater Creek was simulated because it is the largest tributary to the Cimarron River in the model area. Mean annual base flows (January to December) spanning 1935 and 1936 were used to estimate base flow in Stillwater Creek because these were the only complete years of record for this stream. Base flow from Stillwater Creek contributed less than 1 percent of the total flows in the Cimarron River. Many of the other tributaries are ephemeral, and all of the other tributaries contributed negligible amounts of base flow to the model. These tributaries were not simulated, nor were their negligible amounts of base flow incorporated into the model. The base flows determined for the Guthrie and Lovell streamgages were summed and used as the inflows at SFR inflow 1. Base flows from 2016 and 2017 were used to construct the conceptual model data and calibration data. Base flows varied for each month of the transient simulation on the basis of the amount of recharge to the aquifer; however, mean base flows were approximately 30 percent of the mean streamflows for the Cimarron River at each streamgage location (Trevisan and Paizis, 2021).

Initial SFR parameters were streambed hydraulic conductivity of $7 \mathrm{ft} / \mathrm{d}$, streambed thickness of $6 \mathrm{ft}$, streambed width of $500 \mathrm{ft}$ for the Cimarron River, streambed width of 80 $\mathrm{ft}$ for Stillwater Creek, and a roughness coefficient of 0.035 (table 7). These parameters were selected as estimates based on previous Oklahoma alluvial aquifer studies (Adams and others, 1997; Ellis and others, 2017; Smith and others, 2017), which used aerial photography or analyzed site visit data from streamgages. Streambed widths were adjusted during calibration because the Cimarron River frequently splits into multiple channels, so identifying streambed width is difficult. Streambed altitude was set to the altitude of the top of the aquifer derived from the DEM. Altitudes were adjusted to maintain a constant gradient downstream for the SFR package to maintain downstream streamflow routing. Stream extents were also modified so that the SFR package stream course consistently decreased in altitude in the downstream direction as the stream traversed the model extent. Differences were minimal between the SFR package stream course and the stream course determined from the NHDPlus.

\section{Lateral Flow}

Lateral flow boundaries consisted of inflows and outflows from the model domain to and from upstream and downstream areas of the Cimarron River alluvial aquifer that were not simulated. Additionally, the Garber-Wellington aquifer, a bedrock aquifer, supplies water to the aquifer along the southern model boundary from the western boundary to near the Ripley streamgage in the central part of the model (Mashburn and Magers, 2011; Mashburn and others, 2014). These boundaries were simulated using the General-Head Boundary (GHB) package for MODFLOW groundwater-flow models (Harbaugh, 2005) (fig. 18). The GHB package is a hydraulic head-dependent boundary that incorporates the conductance of each GHB package cell. Conductance is the hydraulic conductivity multiplied by the cross-sectional area of a GHB package cell through which groundwater flow is simulated per the thickness of the GHB package cell. Initial water-table altitudes for GHB package cells were set to 0.1 percent higher than the base of the aquifer to control flow to the aquifer and reduce inputs from the GHB package cells. With higher values, flows were much greater than evidenced by the conceptual water budget. GHB package conductance values were adjusted during calibration to control flow into and out of the aquifer.

\section{Groundwater Withdrawals}

Groundwater withdrawals were simulated using the Well (WEL) package for MODFLOW groundwater-flow models (Harbaugh, 2005). The WEL package is a specified-flux boundary that uses user-specified discharge rates to withdraw

Table 7. Hydrologic parameters from the calibrated Cimarron River alluvial aquifer model and from previous studies of alluvial aquifers in Oklahoma.

[ft/d, foot per day; --, not applicable]

\begin{tabular}{|c|c|c|c|c|}
\hline Study & $\begin{array}{c}\text { Specific yield, } \\
\text { percent }\end{array}$ & $\begin{array}{c}\text { Maximum hydraulic } \\
\text { conductivity, } \\
\mathrm{ft} / \mathrm{d}\end{array}$ & $\begin{array}{c}\text { Minimum hydraulic } \\
\text { conductivity, } \\
\mathrm{ft} / \mathrm{d}\end{array}$ & $\begin{array}{c}\text { Mean hydraulic } \\
\text { conductivity, }{ }^{1} \\
\mathrm{ft} / \mathrm{d}\end{array}$ \\
\hline This study & 11 & 120 & 16.0 & 65 \\
\hline Adams and others, 1997 & -- & 104.5 & 47.5 & -- \\
\hline Smith and others, 2017 & 12 & 119 & 8.4 & 46.2 \\
\hline $\begin{array}{c}\text { Reach } 1 \text { of Ellis and } \\
\text { others, } 2017^{2}\end{array}$ & 15.2 & 176 & 0.1 & 45 \\
\hline $\begin{array}{l}\text { Reach } 2 \text { of Ellis and } \\
\text { others, } 2017^{2}\end{array}$ & 16 & 176 & 0.1 & 75 \\
\hline
\end{tabular}

${ }^{1}$ Mean hydraulic conductivity is area weighted.

${ }^{2}$ Ellis and others (2017) studied two extents of the Canadian River alluvial aquifer. 
water from the simulated aquifer. Groundwater withdrawals were derived from OWRB temporary and permanent groundwater permits (OWRB, 2019a). Actual withdrawal rates were not available. One-half of the annual yearly permitted groundwater-withdrawal rate for each well (as described in the "Conceptual Water Budget" section of this report) was used for the steady-state simulation. Groundwater withdrawals for the transient simulations were distributed for each month on the basis of monthly percent groundwater-withdrawal rates outlined by the OWRB (2012) (fig. 19). Groundwater withdrawals were grouped into one of three categories: irrigation, public supply, and other usages. Each category was assigned to a groundwater-withdrawal permit and withdrawals were multiplied by a corresponding value for the groundwaterwithdrawal percentage associated with the month for each transient stress period. Most of the wells used for permitted groundwater withdrawals in the model area are west of the Pawnee Nation subdomain (fig. 5).

\section{Model Calibration}

Model calibration is a process of adjusting model-input parameters to reduce residuals (the differences between historical observed values and simulated values) (Harbaugh and others, 2000; Hill and others, 2000). Inputs include water-table altitude data and derived stream base- flow estimates at streamgages. During calibration, model input parameters are adjusted to reduce residuals while maintaining

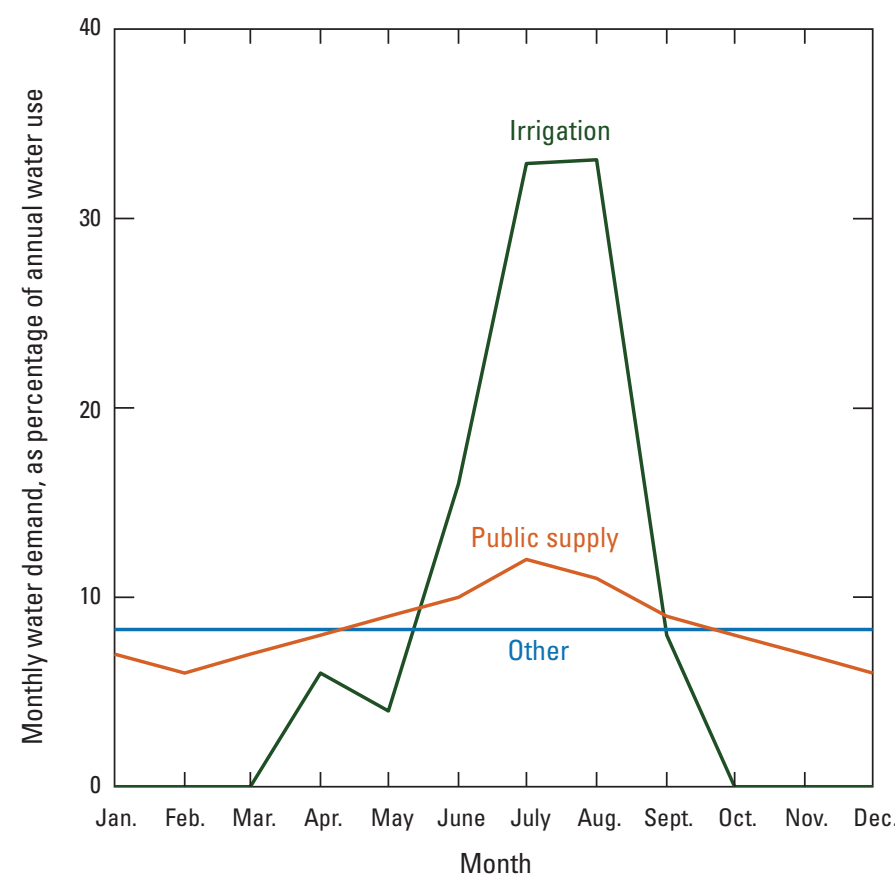

Figure 19. Monthly water demand as percentage of annual water use for irrigation, public supply, and other usages for the upper Arkansas River Basin (modified from Oklahoma Water Resources Board, 2012). hydrogeologically sound input parameters and comparing the simulated water budget to the conceptual water budget. The main goal of calibration is to reduce the objective function $(\Phi)$, which is the sum of the square of the residuals multiplied by the weight values (Hill and others, 2000). Weights are assigned to each observation to weight values so that residuals with orders of magnitude of difference can be compared without biasing calibration to higher magnitude residuals.

The initial process of calibration included manual adjustment of model parameters to reduce residuals through trial and error. The goal of manual calibration was to reduce residuals and increase agreement between simulated and conceptual water budgets. Manual calibration continued until residuals were not decreasing by more than 5 percent through further parameter adjustment.

After manual calibration, automated calibration was performed using the parameter estimation tool (PEST) (Doherty and Hunt, 2010). PEST is an open-source calibration and parameter uncertainty code that utilizes the Gauss-MarquardtLevenberg algorithm to adjust user-specified parameters to reduce residuals (Doherty and Hunt, 2010). PEST adjusts model input parameters and runs the simulation many times to determine optimal input parameters by reducing the objective function $(\Phi)$.

\section{Calibration Parameters}

Five parameter groups totaling 40 parameter observations were used for PEST calibration of the groundwater-flow model. Parameter groups were ET, SFR, recharge, GHB package, and a hydrologic properties group. The hydrologic properties group included vertical anisotropy, hydraulic conductivity, specific yield, and specific storage. For hydraulic conductivity, the values for the alluvium and the terrace deposits were each assigned to separate PEST parameters. The ET extinction depth and ET multiplier (Harbaugh, 2005) were also adjusted during calibration. For SFR, the roughness coefficient, streambed widths, streambed thickness, and streambed hydraulic conductivity were adjusted during calibration. Streambed width for the Cimarron River is difficult to characterize because the channel frequently bifurcates around sand bars. PEST was parameterized to allow streambed width to vary within realistic expected bounds for both the Cimarron River and Stillwater Creek. Other variables were held constant for calibration purposes.

\section{Observations Used for Calibration and Observation Weighting}

Historical observations used for calibration were grouped into two types: water-table altitude observations and base-flow observations. Historical water-table altitudes from July 1971 through October 2018 were obtained from NWIS (USGS, 2019) and included in Trevisan and Paizis (2021). Wells coded for the Cimarron River alluvial aquifer were selected from 
NWIS to obtain water-table altitude observations for use in the groundwater simulation. Well-screen depths were checked against the model base to ensure that observations were from wells representing the alluvial aquifer. Historical water-table altitude observations were generally distributed over the model area but were most numerous in the Pawnee Nation subdomain (fig. 20). A summary of the historical watertable altitudes from July 1971 to October 2018 is provided in table 8 . Historical water-table altitudes were compared to steady-state simulated water-table altitudes. Observations made in years other than 2017 were used to increase the spatial coverage of water-table altitude observations throughout the model. Water-table altitude observations were selected from wells within the alluvial aquifer. Historical water-table altitude observations used to compare to the simulated, steady-state water-table altitudes were computed as a single, mean value when multiple observations for a single location were made across multiple days. For the transient simulation, simulated water-table altitude observations could be obtained at daily increments (wells used to compare historical watertable altitude observations with the steady-state and transient simulated water-table altitude observations are identified [fig. 20]). In a few instances, a mean was obtained from multiple observations made on the same day to obtain a single water-table altitude value; these mean values were compared with the simulated water-table altitude at that location on that day. Water-table altitude observations from 2017 were used to compare with transient-simulated water-table altitudes. These observations were distributed by month and day relative to the corresponding stress period. For example, of the 25 stress periods, representing a steady-state stress period and 2016 through 2017 monthly transient stress periods, May 5, 2017, would be assigned to the 5 th day of the 18 th stress period.

Water-table altitude observations were compared to simulation results by using the Head Observation (HOB) package for MODFLOW groundwater-flow models (Harbaugh and others, 2000; Hill and others, 2000). The HOB package incorporates the cell location of each well and the relative row and column offset from the cell centroid. Observations are assigned to transient stress periods and given a relative time offset. Each transient stress period was associated with 1 month for the simulation. The relative time offset was defined as the number of days since the beginning of the assigned reference stress period (the month associated with the observation). Using the row and column offsets and the relative time offset, the HOB package generates spatially and temporally interpolated water-table altitude observations from the simulated output data.

Base flows from the Ripley and Yale streamgages were compared with simulated base flows. Simulated base flows were obtained using the Gage package for MODFLOW groundwater-flow models (Merritt and Konikow, 2000) and the SFR package. Observed base flows were derived using the BFI for 2016 and 2017. Mean BFI-derived base flows for 2017 were used to compare with steady-state simulated base flows. Monthly BFI-derived base flows were used for the 2016 period and 2017 transient stress periods. BFI-derived base flows tended to be a small fraction of streamflow except for low flow periods, when base flow contributed to most of the streamflow (fig. 14).

Weighting assigns a multiplier to each observation type that is incorporated into PEST to change the contribution of observations to the objective function $(\Phi)$. Weighting was specified to balance the objective function $(\Phi)$ between watertable altitudes and base flow so that each observation type contributed approximately equally to the objective function $(\Phi)$. Water-table altitude observations were assigned a weight of 1 , and base-flow observations were assigned a weight of 1.25 $\times 10^{-6}$. Weighting was based on the initial parameters used prior to PEST calibration. Observations for 2017 were used to compare with steady-state and transient simulated values. These observations from 2017 would inherently be given a higher weight for calibration because these observations were incorporated into the model multiple times compared to other observations that were incorporated once. This weighting scheme was selected because 2017 was the objective timeframe for the model.

\section{Observation Sensitivity Analysis}

An iterative sensitivity analysis was performed for the parameters adjusted during calibration using the PEST (Doherty and Hunt, 2010) software package. The analysis was done by adjusting each parameter upward by 1 percent and calculating the change to the objective function (the sum of squared residuals between the observed and simulated values); these changes are stored in a Jacobian matrix (a matrix with dimensions of the number of observations by the number of calibration parameters) (Doherty and Hunt, 2010). A composite sensitivity value was calculated for each parameter from iteration to iteration by using the following equation included in the PEST software package:

$$
\text { Composite sensitivity }=\left[J^{T} \times Q J\right]^{1 / 2} / n
$$

where

$\begin{array}{cl}J^{T} & \text { is the transpose of the Jacobian matrix, } \\ Q & \text { is the matrix of weights assigned to each } \\ \text { observation, }\end{array}$

Parameters with higher composite sensitivities will impart greater change to the objective function for a given percent change to the parameter value relative to the same percent change to the other parameters. A parameter with zero sensitivity indicates there is no (or almost no) influence to the objective function when that parameter is adjusted upward by 1 percent. The composite sensitivities are represented logarithmically - a difference of 1 between composite sensitivities for two parameters represents a tenfold relative sensitivity 
Table 8. U.S. Geological Survey wells (U.S. Geological Survey, 2019) that provided water-table altitude observations used for calibration of the numerical groundwater-flow model of the Cimarron River alluvial aquifer, 2016-17.

[ft, foot; NAVD 88, North American Vertical Datum of 1988; --, not applicable]

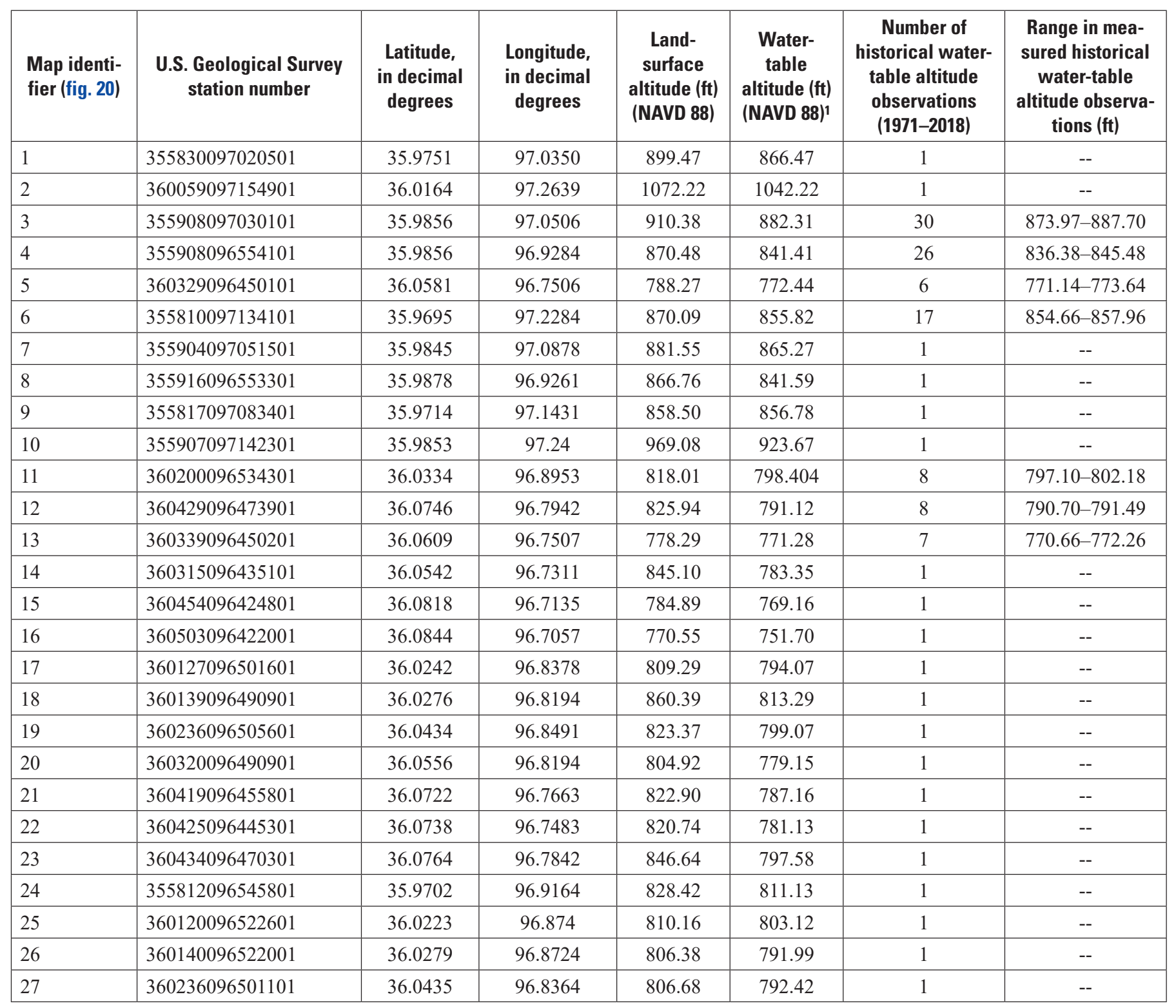

${ }^{1}$ Mean value was reported when there were multiple water-table observations.

difference. This is an effect of the logarithmic transformation applied to the PEST parameters during the analysis (Doherty and Hunt, 2010).

Overall, base-flow observations were less sensitive to calibration parameters than water-table altitude observations (table 9). The highest three base-flow observation composite sensitivities were several orders of magnitude less sensitive to calibration parameters than the highest three water-table altitude observation composite sensitivities. The mean recharge array multiplier used for the steady-state simulation (rchavgm) and the hydraulic conductivities for the alluvium and terrace deposits (condalluv and condtrrc, respectively) were the most sensitive parameters for water-table altitude observations. The spatial distribution of hydraulic conductivity was simulated as zones. A change in hydraulic conductivity for a single zone would affect multiple observations contributing to a greater change to the objective function and thus higher composite sensitivities. Observations were likely more sensitive to the recharge multiplier because recharge represents the largest source of water to the aquifer (fig. 22) and recharge is widely distributed throughout the model (fig. 17). 


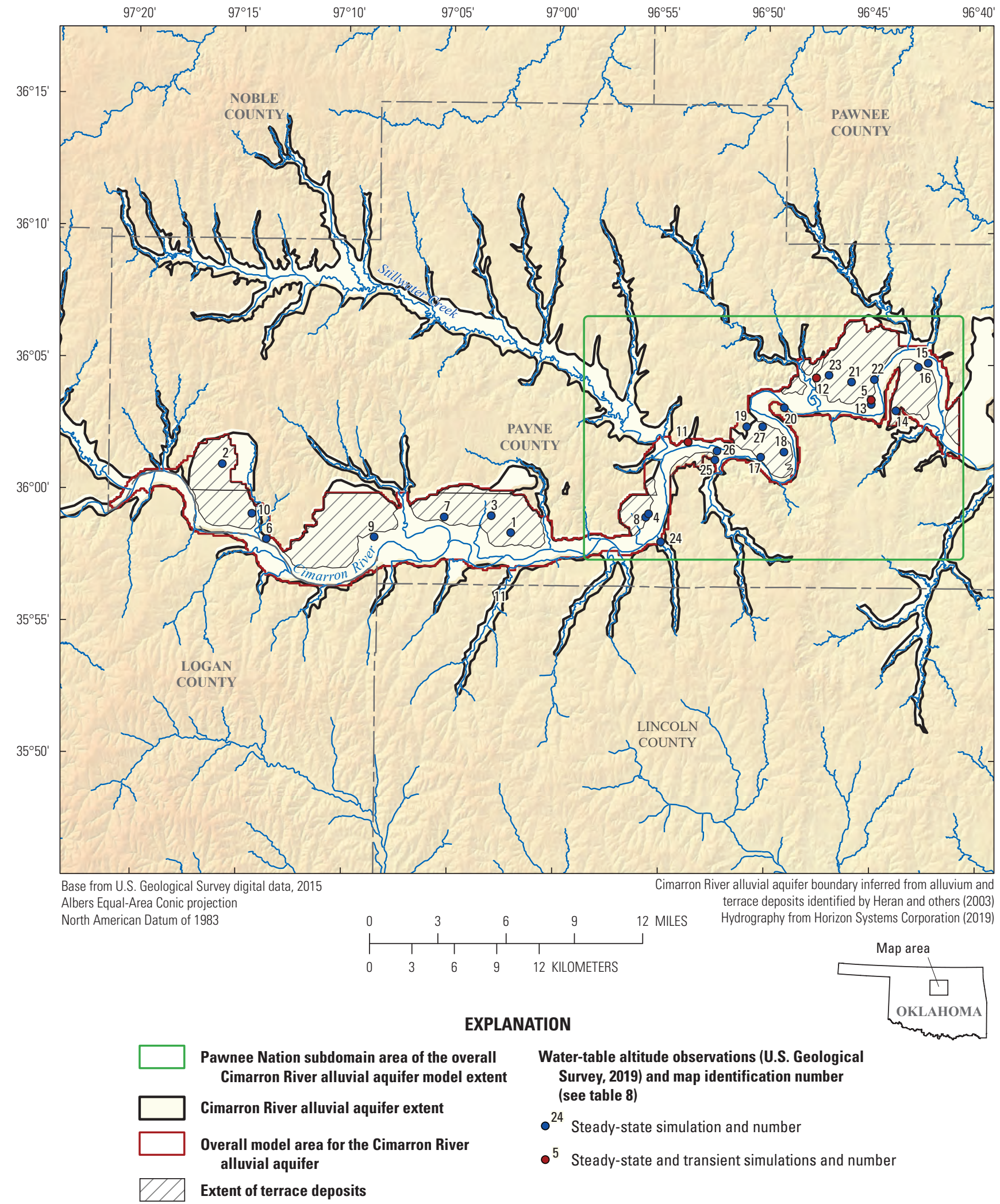

Figure 20. Locations of water-table altitude observations and map identifier (table 8) and the extent of terrace deposits. 
Table 9. Selected composite sensitivities from the parameter estimation tool (PEST; Doherty and Hunt, 2010) sensitivity analysis as a composite of all sensitivities for all observation types, for water-table altitude observations and for base-flow observations. A table with all parameter sensitivities can be found in the associated data release (Trevisan and Paizis, 2021).

[Ranks are based on the complete list of calibration parameters that are available in the associated data release (Trevisan and Paizis, 2021)]

\begin{tabular}{|c|c|c|c|c|c|c|c|}
\hline $\begin{array}{l}\text { Parameter } \\
\text { name }\end{array}$ & $\begin{array}{l}\text { Parameter } \\
\text { description }\end{array}$ & $\begin{array}{l}\text { All observa- } \\
\text { tion composite } \\
\text { sensitivities } \\
{ }^{1} \\
\text { (dimensionless) }\end{array}$ & $\begin{array}{c}\text { Rank of all } \\
\text { observation } \\
\text { composite } \\
\text { sensitivities } \\
\text { (dimensionless) }\end{array}$ & $\begin{array}{l}\text { Water-table } \\
\text { altitude } \\
\text { observations } \\
\text { composite } \\
\text { sensitivities }^{1} \\
\text { (dimensionless) }\end{array}$ & $\begin{array}{l}\text { Rank of water- } \\
\text { table altitude } \\
\text { observations } \\
\text { composite } \\
\text { sensitivities } \\
\text { (dimension- } \\
\text { less) }\end{array}$ & $\begin{array}{l}\text { Base-flow } \\
\text { observation } \\
\text { composite } \\
\text { sensitivities' } \\
\text { (dimension- } \\
\text { less) }\end{array}$ & $\begin{array}{l}\text { Rank of base- } \\
\text { flow observa- } \\
\text { tion composite } \\
\text { sensitivities } \\
\text { (dimension- } \\
\text { less) }\end{array}$ \\
\hline rchavgm & $\begin{array}{l}\text { Multiplier for } \\
\text { average } \\
\text { recharge } \\
\text { array }\end{array}$ & 1.513 & 1 & 3.095 & 1 & 0.241 & 2 \\
\hline condtrrc & $\begin{array}{l}\text { Hydraulic } \\
\text { conductivity } \\
\text { of terrace } \\
\text { geology }\end{array}$ & 1.163 & 2 & 2.385 & 2 & 0.067 & 15 \\
\hline condalluv & $\begin{array}{l}\text { Hydraulic } \\
\text { conductivity } \\
\text { of alluvium } \\
\text { geology }\end{array}$ & 0.568 & 3 & 1.150 & 3 & 0.184 & 5 \\
\hline ghb3 & $\begin{array}{l}\text { GHB con- } \\
\text { ductance } \\
\text { of southern } \\
\text { boundary } \\
\text { represent- } \\
\text { ing Central } \\
\text { Oklahoma } \\
\text { aquifer } \\
\text { (known } \\
\text { locally and } \\
\text { referred to } \\
\text { herein as the } \\
\text { "Garber- } \\
\text { Wellington } \\
\text { aquifer") }\end{array}$ & 0.324 & 4 & 0.141 & 7 & 0.618 & 1 \\
\hline $\operatorname{rch} 201704 \mathrm{~m}$ & $\begin{array}{l}\text { Multiplier for } \\
\text { April } 2017 \\
\text { recharge } \\
\text { array }\end{array}$ & 0.135 & 5 & 0.159 & 6 & 0.216 & 3 \\
\hline
\end{tabular}

${ }^{1}$ Composite sensitivities are on a logarithmic scale.

\section{Calibration Results}

Water-table altitude residuals and base-flow residuals were identified for each observation. Residuals were determined by the difference between observed values and their simulated values. A residual of zero indicates that the observed value matches the simulated value. Manual calibration was continued until changes to model parameters did not reduce residuals by more than 5 percent. Further, automated calibration using PEST was completed to better estimate optimal parameters and lower residuals on the basis of the specified objective function $(\Phi)$.

Hydrologic parameters generally were within ranges of those in other studies for Oklahoma alluvial aquifers (table 7). Calibrated hydraulic conductivity values were $120 \mathrm{ft} / \mathrm{d}$ for the alluvium deposits and $16.0 \mathrm{ft} / \mathrm{d}$ for the terrace deposits in this study and ranged from 0.1 to $176 \mathrm{ft} / \mathrm{d}$ in the other studies. The range of calibrated hydraulic conductivity values falls within the range of hydraulic conductivities for clean sands or silty sands (Freeze and Cherry, 1979; Heath, 1983). Specific yield 
was 11 percent for the calibrated model, close to that in Smith and others (2017), who found a value of 12 percent for the North Fork of the Red River alluvial aquifer. Ellis and others (2017) found higher rates, around 16 percent, for the Canadian River alluvial aquifer. The calibrated specific yield of 0.10 in this study falls within the typical range of specific yield for unconfined aquifers of 0.01 to 0.30 (Freeze and Cherry, 1979).

A calibrated simulated saturated aquifer thickness was assigned to each model cell. Calibrated simulated saturated aquifer thickness values ranged from less than 1 to $80.9 \mathrm{ft}$ (table 6); the mean value was $28.5 \mathrm{ft}$. Model cells with the indicated number of saturated aquifer thickness values are depicted with the data binned in increments of $10 \mathrm{ft}$ (each bin represents approximately $10 \mathrm{ft}$ of saturated thickness) (fig. 21). The calibrated simulated saturated aquifer thicknesses of most model cells ranged from 10 to $60 \mathrm{ft}$ (fig. 21).

\section{Calibrated Water Budget}

Mean annual groundwater inflows and outflows (in acre-feet per year and inches per year) of the conceptual and simulated water budgets were determined from the transient stress periods for the Pawnee Nation subdomain (fig. 22). Percent differences between conceptual and simulated water budgets were within plus or minus 4 percent (table 5). ET only accounted for about 10 percent of total aquifer outflows and lateral flow only accounted for about 15 percent of total aquifer outflows (table 5). ET makes up a small percentage of total flows, and the inflows and outflows with the highest percentage of flow (recharge and stream seepage) compare closely with the conceptual and simulated water budgets. A percent difference of +2.5 percent for stream seepage was calculated (table 5), indicating that stream seepage was slightly overestimated in the simulation compared to the conceptual water budget. Recharge and groundwater withdrawals matched closely between the conceptual and simulated water budgets (the percent differences between the conceptual and simulated water budgets for recharge and groundwater withdrawals were within plus or minus 3 percent). The percent differences between the conceptual and simulated water budgets were -1.7 percent for inflows and +1.3 percent for outflows. Wellwithdrawal estimates were nearly identical for calibrated and simulated water budgets because the estimates and implementation in the simulation were from the same permit data. Groundwater withdrawals accounted for about 14 percent of the water budget. The simulated inflows were higher than the conceptual water budget and simulated outflows were lower than the conceptual water budget for the Pawnee Nation subdomain.

\section{Comparison of Simulated and Observed Values}

Calibration results were analyzed using observed watertable altitudes in the alluvial aquifer and base flows in streams. Residuals between observed and simulated and root mean square errors (RMSEs) were calculated for each observation type. RMSE values were $14.1 \mathrm{ft}$ for steady-state water-table

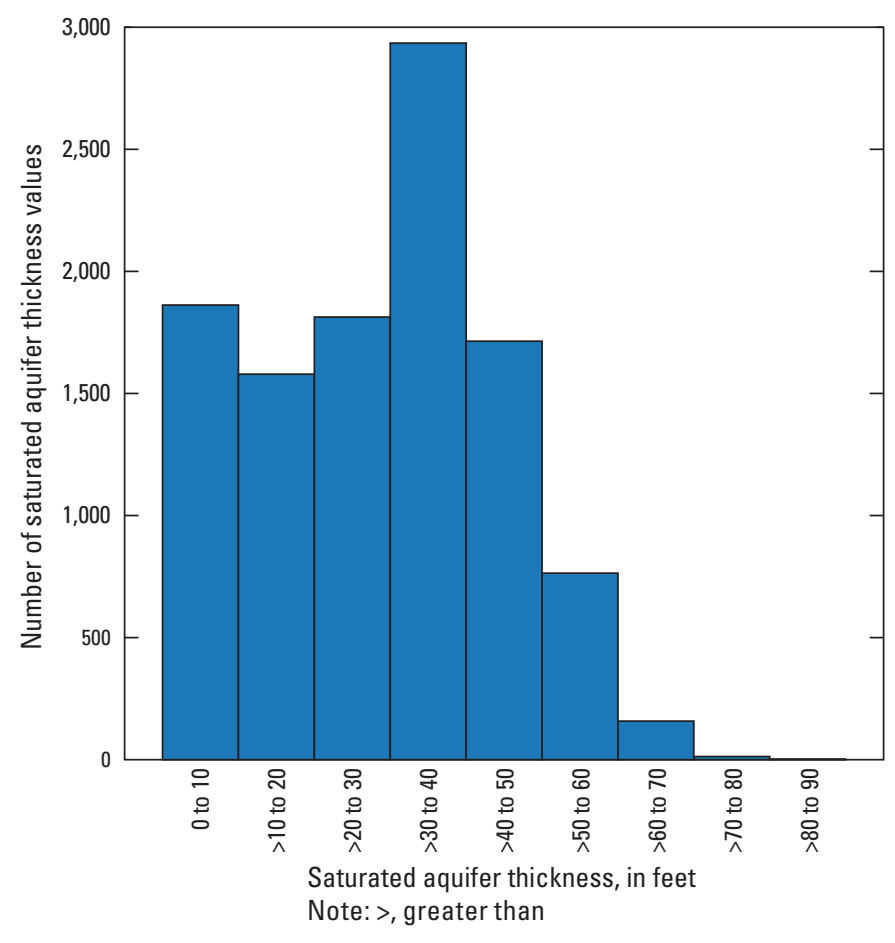

Figure 21. Number of saturated aquifer thickness values assigned to model cells. Values were binned with each bin representing approximately 10 feet of saturated aquifer thickness.

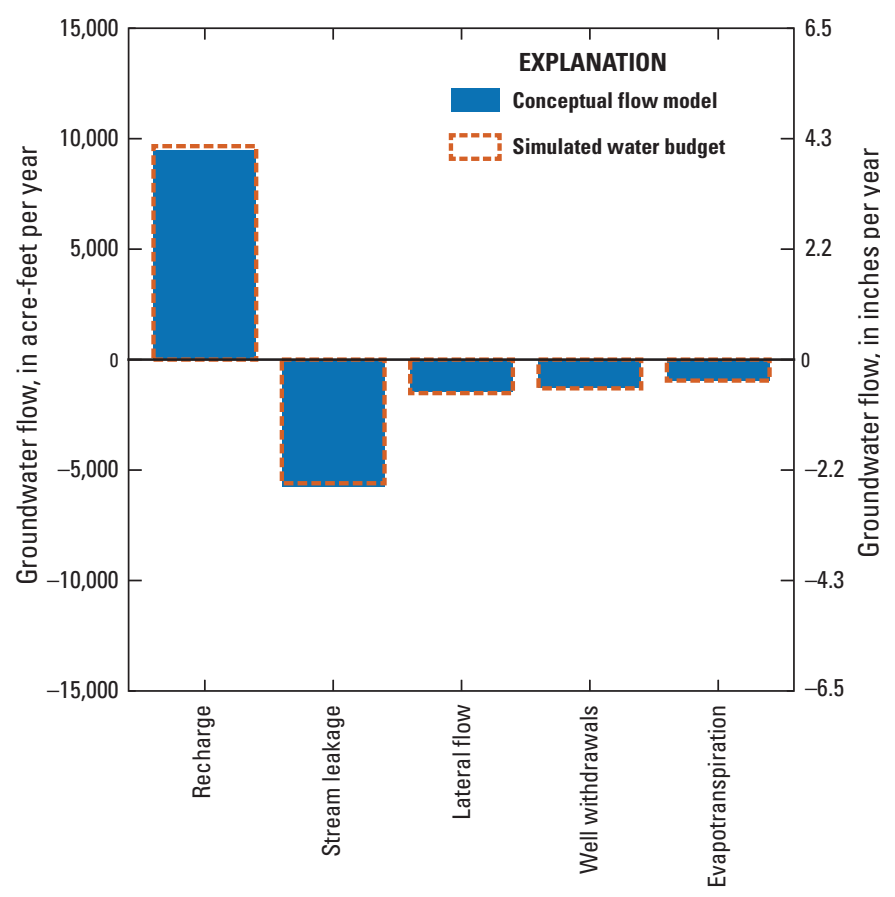

Figure 22. Conceptual groundwater-flow model and simulated water budget for the Pawnee Nation subdomain of the Cimarron River alluvial aquifer model extent, with negative values indicating outflows and positive values indicating inflows. Mean simulated values were determined from the transient stress periods. 
altitude observations and $3.9 \mathrm{ft}$ for the transient simulation values (table 10). Hydraulic conductivities were constant for the alluvium and terrace deposits simulation (Trevisan and Paizis, 2021). If hydraulic conductivity heterogeneity was allowed more spatial variability during calibration, then water-table altitudes might better match simulated values. In contrast, measurements made in the higher elevation terrace deposits plot to the left of the 1:1 line, which indicates a bias towards lower simulated water-table altitudes relative to the observed water-table altitudes. The largest residuals between simulated and observed water-table altitudes were found in the terrace deposits (as indicated by the difference between a watertable altitude value and the 1:1 line in fig. 23) likely because of rapid draining of the terrace deposits in the simulation. Hydraulic conductivity was discretized between the alluvium and terrace deposits to reduce this effect.

Simulated base flows matched the overall pattern of base flows derived using BFI methods (that is, the observed base flows) (fig. 24), and simulated base flows closely matched the values of observed base flows for the 2016 to 2017 transient stress periods. In some instances, such as at the Ripley gage, simulated base flows were nearly identical to observed base flows in the early part of 2017 (fig. 24A). Overall, simulated base flows at the Ripley gage tended to be lower than observed base flows, particularly for the 2016 simulation. The Yale streamgage was installed in late September 2016 and observed base flows could be determined only for November 2016 through December 2017 (fig. 24B). Base-flow RMSEs for the Yale streamgage were large (about $155 \mathrm{ft}^{3} / \mathrm{s}$ for the transient simulation and $174 \mathrm{ft}^{3} / \mathrm{s}$ for the steady-state simulation; Trevisan and Paizis, 2021). These base-flow RMSEs are large because the simulated base-flow values tended to match poorly with observed base-flow values for 2016. Simulated base-flow values tended to match better with observed base-flow values for 2017, which was prioritized as the period with the most data for the Cimarron River alluvial aquifer model.

\section{Long-Term Streamflow Capture Analysis- Implications for Future Water Availability}

To better understand the possible effects that proposed new water-resource development (such as additional diversion of surface water and extraction of groundwater) might have on the future water availability, streamflow capture analysis was applied to the steady-state simulation to identify areas of the aquifer where base flows in the Cimarron River were most sensitive to groundwater withdrawals. Streamflow capture is defined as the change in base flow at the outlet of a stream resulting from a change in the groundwater-withdrawal rate at an individual well independent of other changes in groundwater withdrawal or recharge occurring contemporaneously throughout the aquifer (Barlow and Leake, 2012). Streamflow capture is determined by using the following equation:

Table 10. Residual and objective function $(\Phi)$ components for the numerical groundwater-flow model of the Cimarron River alluvial aquifer, 2016-17.

[USGS, U.S. Geological Survey; RMSE, root mean square error]

\begin{tabular}{|c|c|c|c|c|}
\hline \multirow{2}{*}{$\begin{array}{c}\text { Source } \\
\text { Simulation }\end{array}$} & \multicolumn{2}{|c|}{$\begin{array}{l}\text { USGS water-table altitude observation, } \\
\text { in feet (USGS, 2019) }\end{array}$} & \multicolumn{2}{|c|}{$\begin{array}{l}\text { USGS streamgage } 07161450 \text { Cimarron River near Ripley, Okla., } \\
\text { and USGS streamgage } 07163300 \text { Cimarron River near Yale, Okla., } \\
\text { streamflow, in cubic feet per day (USGS, 2019) }\end{array}$} \\
\hline & Steady state & Transient & Steady state & Transient \\
\hline $\begin{array}{l}\text { Number of } \\
\text { observations }\end{array}$ & 27 & 11 & 2 & 38 \\
\hline Weight multiplier & 1 & 1 & 0.00000125 & 0.00000125 \\
\hline Mean & 3.9 & -4.9 & $14,900,000$ & $8,000,000$ \\
\hline Maximum & 43.9 & 0.2 & $17,100,000$ & $47,900,000$ \\
\hline RMSE & 15.2 & 5.4 & $15,100,000$ & $13,400,000$ \\
\hline $\begin{array}{l}\text { Objective function } \\
\text { (Ф) }\end{array}$ & 6,232 & 323 & 709 & 10,661 \\
\hline RMSE & 14.1 & 3.9 & $14,800,000$ & $13,200,000$ \\
\hline $\begin{array}{l}\text { Objective function } \\
\text { (Ф) }\end{array}$ & 5,363 & 169 & 688 & 10,289 \\
\hline
\end{tabular}




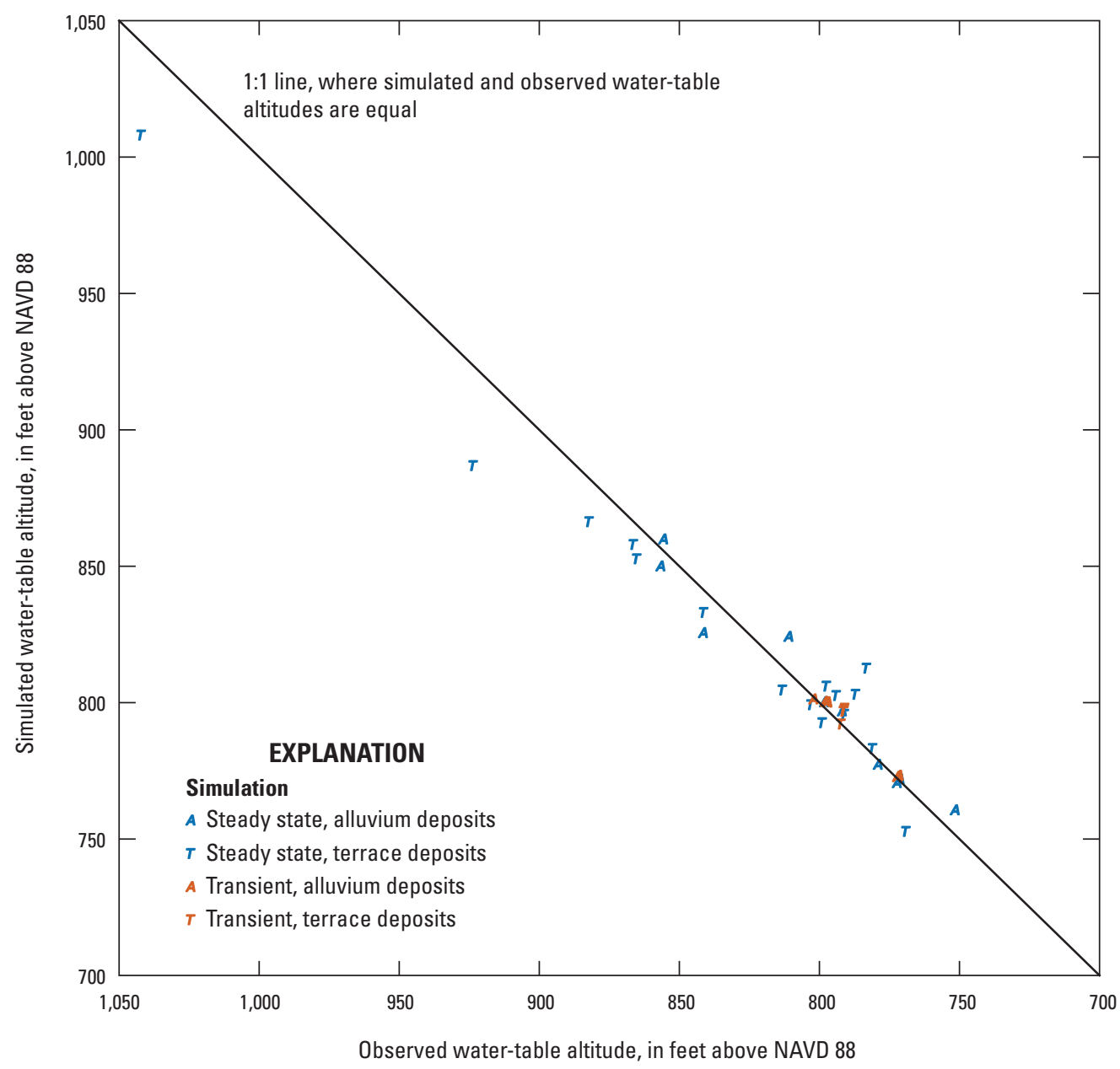

Figure 23. Relation between simulated and observed water-table altitudes between alluvium and terrace deposits, as well as between transient and steady state, respectively, in feet above the North American Vertical Datum of 1988 (NAVD 88), for the Pawnee Nation subdomain of the Cimarron River alluvial aquifer model.

$$
\text { Stream capture }=q_{k, i, j}-q_{\text {base }} / q_{\text {well }}
$$

where

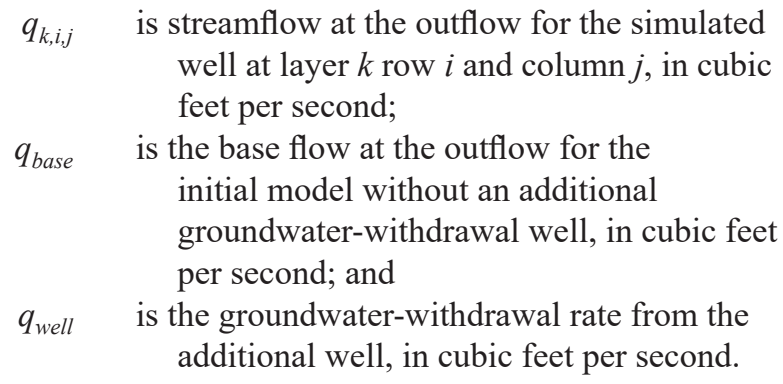

Streamflow capture was simulated by using the calibrated steady-state model. An observation at the outlet of the Cimarron River was used to identify changes in base flow for the stream. Because the SFR package routes water downstream, the outflow incorporates all changes in base flows upstream from that point. The initial base-flow value $\left(q_{\text {base }}\right)$ was assigned the value of the SFR stream outflow for the calibrated steady-state, base model. Subsequent simulations were run in each active cell in the Pawnee Nation subdomain for a specified groundwater-withdrawal rate of 180,000 cubic feet per day. The groundwater-withdrawal rate of 180,000 cubic feet per day represents approximately a 34 percent increase compared to the highest permitted groundwater-withdrawal rate for an individual well. A 34 percent increase was applied to represent the estimated 34 percent increase in groundwater withdrawals predicted by 2060 for the upper Arkansas River Basin (OWRB, 2012).

Simulated streamflow capture was highest in the alluvium deposits adjacent to the Cimarron River; that is, base flow in the Cimarron River decreased the most for simulated groundwater withdrawals in the alluvium deposits adjacent to the Cimarron River (figs. 6 and 25). Streamflow capture increased as the distance of a well from the Cimarron River decreased in the simulation. The northeastern part of the Pawnee Nation subdomain showed greater streamflow capture in a broader 

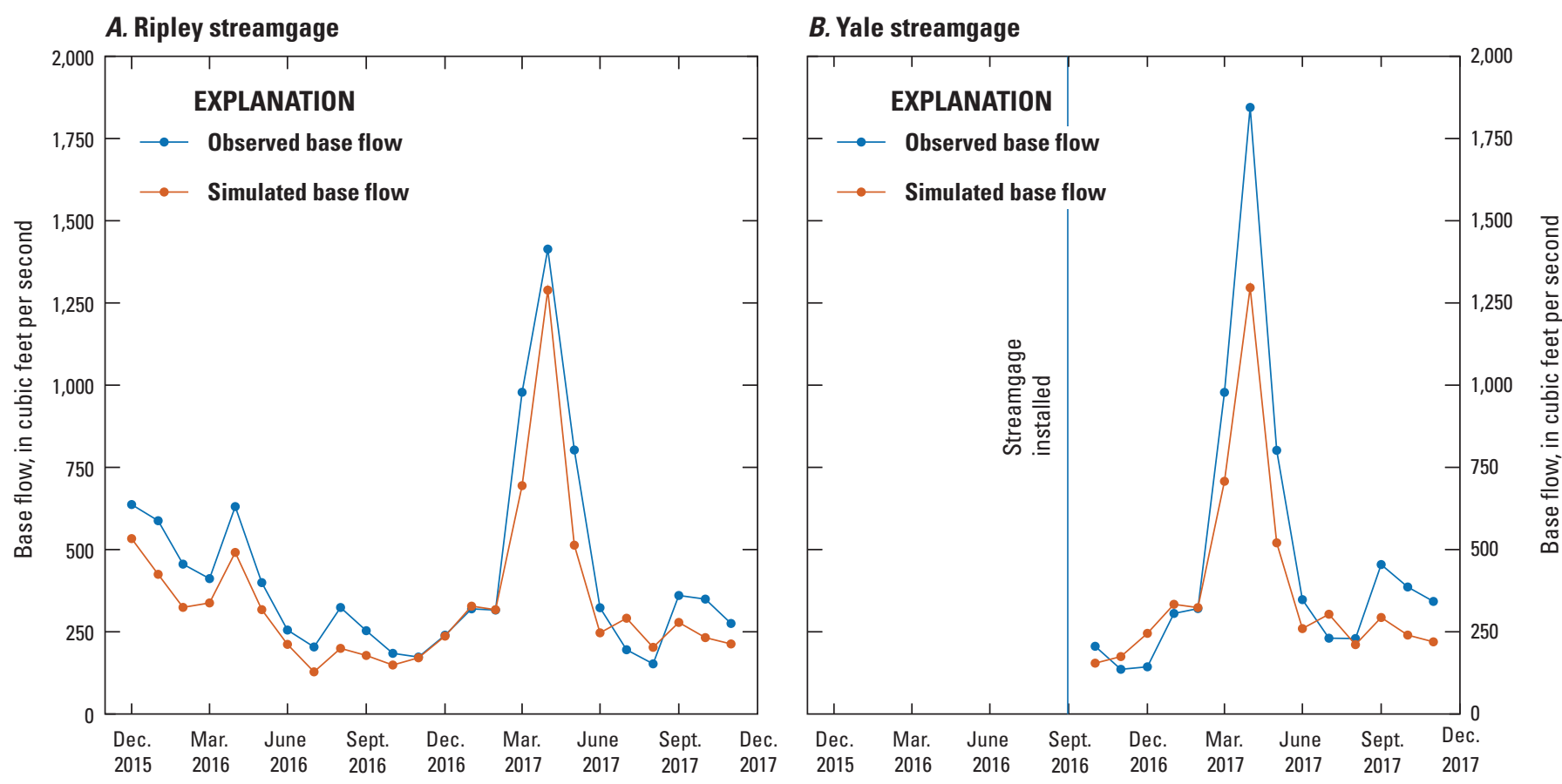

Figure 24. Observed versus simulated base flows for transient simulations of the Cimarron River alluvial aquifer model at two U.S. Geological Survey (USGS) streamgages in the Pawnee Nation subdomain of the overall model area for the Cimarron River alluvial aquifer, Payne County, north-central Oklahoma. A, USGS streamgage 07161450 Cimarron River near Ripley, Okla. (Ripley streamgage), December 2015 to December 2017. B, USGS streamgage 07163300 Cimarron River near Yale, Okla. (Yale streamgage), 0 ctober 2016 to December 2017.

area; streamflow in that part of the Pawnee Nation subdomain is likely more sensitive to groundwater withdrawals compared to other parts of the Pawnee Nation subdomain.

\section{Model Assumptions and Limitations}

Because of the uncertainty associated with many of the model parameters, the limitations of this groundwater simulation are described to aid readers in their interpretation and application of the results described in this report. The groundwater simulation required several assumptions to simplify the model. MODFLOW code follows Darcy's law to simulate groundwater flow. Darcy's law assumes that water is of uniform density and incompressible (Freeze and Cherry, 1979). The cell size for the groundwater simulation was assumed to appropriately sample hydrogeologic variability within the aquifer while maintaining reasonable simulation times. Therefore, actual groundwater conditions will not be identical to those simulated by the groundwater simulation. Additionally, hydrogeologic heterogeneity for many model parameters (such as specific yield and hydraulic conductivity) were not well known throughout the aquifer and study area. It would not be appropriate to use the scenarios documented in Trevisan and Paizis (2021) to interpret local or temporal responses or local groundwater availability for specific locations. Composite sensitivities for water-table altitude observations were higher than base-flow composite sensitivities (table 9) and likely a result of the lack of spatial heterogeneity for hydraulic conductivity in the model. Uncertainties are likely higher in areas with few or no water-table altitude observations.

There were spatial and temporal data gaps for groundwater water-table altitude observations and streamflow measurements at the streamgages. Furthermore, hydrologic conditions vary considerably from year to year. Because most of the data used to calibrate the model were collected during 2017, the results from this model describe hydrologic conditions during 2017 and may not be applicable to other years with different hydrologic conditions.

The Cimarron River and a small reach of Stillwater Creek were the only streams included in the groundwater simulation. Because few data from tributaries were included in the model, the results from streamflow capture analysis only pertain to reduction in base flows along the Cimarron River and do not show the effects of reduced base flows on tributaries to the Cimarron River. Effects on groundwater availability with respect to tributaries cannot be inferred from the groundwater simulation. Results from the model are appropriate for inferring general aquifer groundwater-withdrawal sensitivities to changes in base flow. These results are not appropriate for inferring a specific reduction in base flows for implementation of a groundwater-withdrawal amount for a well at a specific locality. Numerical error from rounding or truncation and 


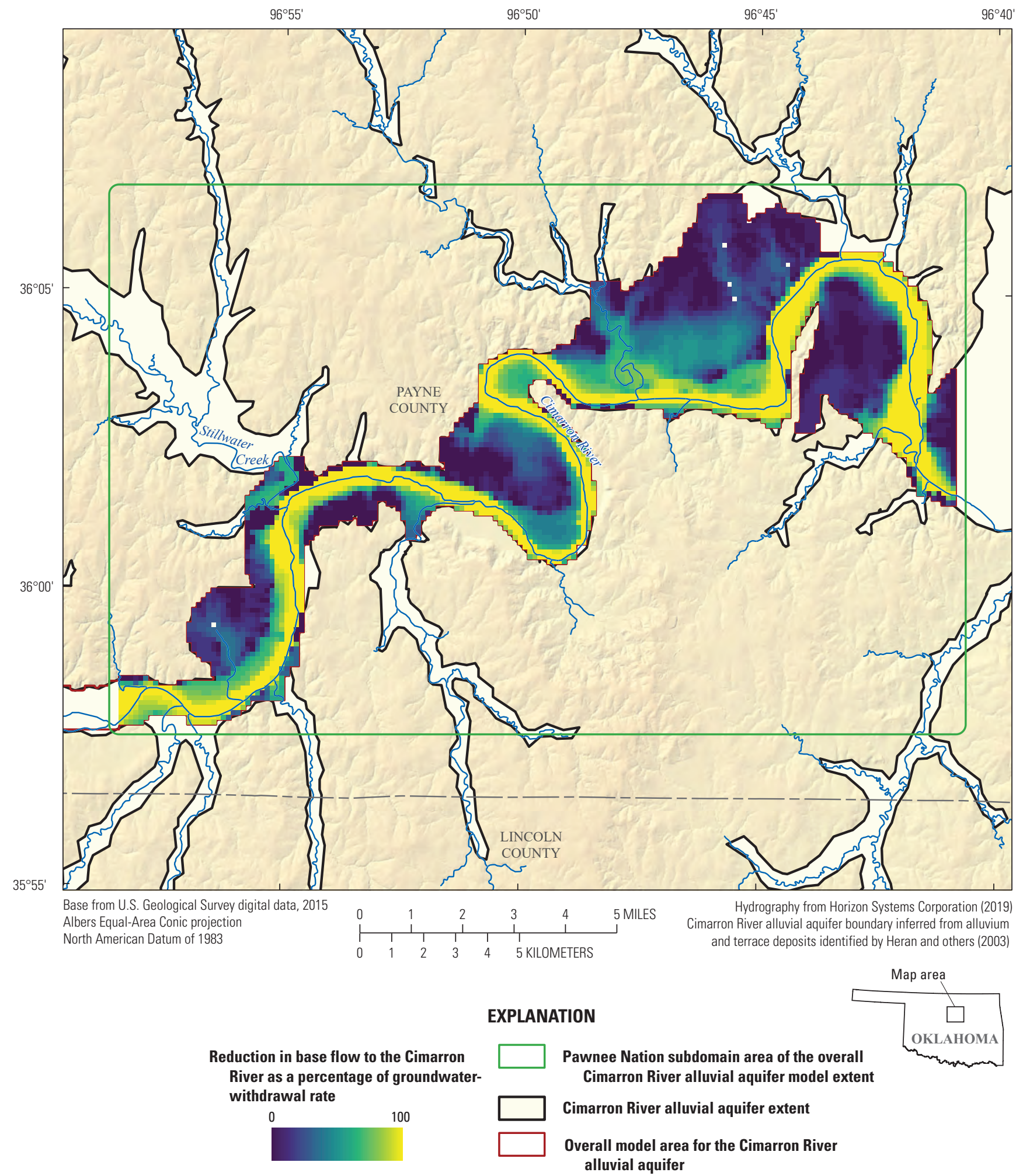

Figure 25. Streamflow capture for the Pawnee Nation subdomain of the Cimarron River alluvial aquifer model extent, Payne County, north-central Oklahoma. 
parameter precision can be a large component of streamflow capture uncertainty (Ahlfeld and Hoque, 2008). Some aquifer parameters implemented into the groundwater simulation were based on estimates within the hydrogeologic constraints for the model area.

Groundwater withdrawals for specific wells were not available for the study, and groundwater withdrawal rates were inferred from permitted groundwater-withdrawal rates as explained in the "Groundwater Withdrawals" section of this report. Exact values for groundwater withdrawals could vary from those simulated in the groundwater model. Wells that do not require permits were not represented in the model. These wells typically include domestic wells and do not typically withdraw rates that would change the conceptual water budget by more than a fraction of a percent. Information obtained from the model documented by this report might help to identify areas where groundwater withdrawal would be more likely to reduce base flow, as the hydrologic data show a highly connected surface-water and groundwater exchange in the alluvium.

\section{Summary}

Increased demand for water resources within the Cimarron River alluvial aquifer in north-central Oklahoma (primarily in Payne County) has led to increases in groundwater withdrawals for agriculture, public, irrigation, industrial, and domestic supply purposes. Groundwater in the Cimarron River alluvial aquifer are used extensively for irrigation, stock, municipal, and domestic supplies. The Pawnee Nation of Oklahoma is particularly concerned about the sustainability of the Cimarron River alluvial aquifer and whether the aquifer will continue to be a viable water resource for future generations of Tribal members and residents. To better understand current (2021) water resources and possible future water availability in the Pawnee Nation Tribal jurisdictional area, the U.S. Geological Survey, in cooperation with the Bureau of Indian Affairs and the Pawnee Nation of Oklahoma, compiled available hydrogeologic data and developed conceptual and numerical groundwater-flow models for the Cimarron River alluvial aquifer in Payne County, north-central Oklahoma, including a focus area in the Pawnee Nation Tribal jurisdictional area.

Various hydrogeologic data were measured to assist with model development, including depth to bedrock and watertable altitude data. In support of the model development, analyses pertaining to groundwater flow, groundwater/surfacewater interactions, base flows in the Cimarron River, and lithological interpretations in the Pawnee Nation subdomain of the Cimarron River alluvial aquifer model extent (Pawnee Nation subdomain) were used to compute a mean annual water budget applicable to the 2016-18 study period. Total groundwater withdrawals were estimated as 1,300 acre-feet per year for the Pawnee Nation subdomain. The numerical groundwater-flow model documented in this report can help water managers evaluate the current (2021) water resources of the Pawnee Nation of Oklahoma and assist managers in determining the possible effects that proposed new water-resource development (such as additional diversion of surface water and withdrawal of groundwater) might have on the future water availability. Base-flow values were estimated using the baseflow index from streamflow data collected at U.S. Geological Survey streamgages. Stream seepage values were derived from the mean 2017 base-flow index between certain streamgages. Hydraulic conductivities were specified an initial (before calibration) value of 120 feet per day for the alluvium deposits and 16 feet per day for the terrace deposits.

Most of the analysis and statistics were completed on the Cimarron River alluvium and terrace deposits in the Pawnee Nation subdomain. The Cimarron River is a free-flowing river and is a major source of water as it flows across Oklahoma. The Cimarron River alluvial aquifer alluvium and terrace deposits range in thickness from 20 to 120 feet. The deposits consist primarily of sand, gravel, silt, and clay. Occasional sand dunes with large-scale crossbedding are also present on the floodplain along the Cimarron River. Where alluvium deposits are exposed along the Cimarron River, sand and gravel with interbeds of clay are usually found in a fining upward sequence. The sand is tan to brownish red and characterized by horizontal bedding and small-scale crossbedding. Precipitation is the major source of recharge to the Cimarron River alluvial aquifer. In general, only a small amount of total precipitation becomes groundwater; before it can infiltrate the aquifer, most precipitation is lost to evapotranspiration or surface runoff. Groundwater is discharged from the aquifer by seepage into the Cimarron River and its perennial tributaries (meaning the stream derives part of its streamflow from groundwater), making the Cimarron River a gaining stream throughout most of its extent. Seepage also occurs into the Permian-age geologic units underlying the alluvial aquifer, such as the Central Oklahoma aquifer and the Ada-Vamoosa aquifer; evidence of seepage into the underlying geologic units has been documented in isolated areas across the aquifer. The amount of groundwater seepage from the Cimarron River alluvial aquifer to the Permian units depends on the hydraulic gradient, the cross-sectional area of flow, and the hydraulic conductivity of the Permian units. Three groundwater wells completed in the Cimarron River alluvial aquifer were instrumented with vented pressure transducers set to continuously monitor water-table altitudes across the aquifer. During spring and summer, declining water-table altitudes were primarily associated with seasonally higher rates of groundwater withdrawal for agricultural use during the growing season from April through September; ET depletions of groundwater are also highest in spring and summer.

Water-table altitudes were higher in wells completed in bedrock compared to those measured in wells completed in alluvium deposits, thereby indicating that the Cimarron River has incised down into the bedrock, with some seepage through this alluvial system. Groundwater in the alluvium deposits 
typically flows at right angles to the direction of streamflow; results of this study indicate that groundwater flows regionally from west to east at a right angle to the flow direction of the Cimarron River. The amount of streamflow increased between each streamgage in the downstream direction. Over the course of each year of the study, streamflows typically were highest during April and May and lowest during November and December. Inflows from tributaries between sites on the Cimarron River were smaller than the gains in streamflow measured on the main stem sites, indicating that groundwater inflows likely accounted for much of the increase in base flow in the downstream direction on the Cimarron River.

The mean horizontal hydraulic conductivity for the Cimarron River alluvial aquifer was estimated as 45 feet per day, the maximum as 141 feet per day, and the minimum as 8 feet per day. These horizontal hydraulic conductivities are in the lower part of the range of those published in a previous report for a reach of the Cimarron River alluvial aquifer farther west of the current study area. Local variations in the percentage of coarse material in the alluvial aquifer materials may be related to the depositional history and the variability of the lithologic-log descriptions provided by different well drillers. Lateral flows were identified as inflows along the western model boundary and outflows through the eastern boundary of the model. Additionally, the Garber-Wellington aquifer abuts the southern part of the Cimarron River alluvial aquifer in the model area. Flow can enter and exit the Cimarron River alluvial aquifer along this boundary. Lateral-flow constraints were unknown. Lateral flow was likely a minimal component to the water budget and was estimated to be 1,450 acre-feet per year, which was about 16.2 percent of outflow from the aquifer. Recharge rates ranged from 0 to 7.5 inches per year. The amount of recharge to the Cimarron River alluvial aquifer was generally higher in the alluvium deposits near the Cimarron River than in the alluvium deposits farther away from the river.

Streamflow capture analysis was applied to the steadystate simulation to identify areas of the aquifer where base flows in the Cimarron River were most sensitive to groundwater withdrawals. The initial base-flow value was assigned the value obtained from streamflow-routing software used to simulate stream outflow for the calibrated steady-state base model. Subsequent simulations were run in each active cell in the Pawnee Nation subdomain for the specified groundwaterwithdrawal rate of 180,000 cubic feet per day. The study area that includes the Pawnee Nation subdomain is in the upper Arkansas River Basin. A groundwater-withdrawal rate of 180,000 cubic feet per day represents a 34 percent increase compared to the highest permitted groundwater-withdrawal rate for the study area, which corresponds to the estimated 34 percent increase in groundwater withdrawals predicted by 2060 for the upper Arkansas River Basin. Simulated streamflow capture was highest in the alluvium deposits adjacent to the Cimarron River; that is, base flow in the Cimarron River decreased the most for simulated groundwater withdrawals in the alluvium deposits adjacent to the Cimarron River.
Hydrologic parameters generally were within ranges of other studies for Oklahoma alluvial aquifers. Calibrated hydraulic conductivity values were 120 feet per day for the alluvium deposits and 16 feet per day for the terrace deposits. The calibrated range of hydraulic conductivity falls within the range of hydraulic conductivities for clean sands or silty sands. Specific yield was 11 percent for the calibrated model, which was close to the value of 12 percent reported for the North Fork of the Red River alluvial aquifer in a previous study. Calibrated simulated saturated aquifer thickness ranged from less than 1 to 80.9 feet. Calibrated mean simulated saturated aquifer thickness was 28.5 feet. The calibrated simulated saturated aquifer thicknesses of most model cells ranged from 10 to 60 feet. Overall, simulated base flows closely matched the observed base flows for the 2016-17 transient stress periods. Streamflow root mean square errors were large (about 155 cubic feet per second for the transient simulation and 174 cubic feet per second for the steady-state simulation). The simulated inflows were higher than the conceptual water budget, and the simulated outflows were lower than the conceptual water budget for the Pawnee Nation subdomain. Areas within the alluvium had the highest streamflow capture closer to the Cimarron River; that is, base flow in the Cimarron River decreased the most for groundwater withdrawal in the alluvium areas. The northeastern part of the Pawnee Nation subdomain showed greater stream capture in a broader area and is likely more sensitive to groundwater withdrawal. These hydrogeologic data and the conceptual groundwater-flow model can be used to assist in determining the rate of baseflow decrease that surface-water diversions and groundwater withdrawals have on the Cimarron River. This information can help to identify areas where groundwater withdrawal would be more likely to reduce base flow, as the hydrologic data show a highly connected surface-water and groundwater exchange in the alluvium.

\section{References Cited}

Ackerman, D.J., Rousseau, J.P., Rattray, G.W., and Fisher, J.C., 2010, Steady-state and transient models of groundwater flow and advective transport, Eastern Snake River Plain aquifer, Idaho National Laboratory and vicinity, Idaho: U.S. Geological Survey Scientific Investigations Report 2010-5123, 220 p., accessed June 25, 2021, at https://doi.org/10.3133/sir20105123.

Adams, G.P., and Bergman, D.L., 1996, Geohydrology of alluvium and terrace deposits of the Cimarron River from Freedom to Guthrie, Oklahoma: U.S. Geological Survey Water-Resources Investigations Report 95-4066, 57 p., accessed August 27, 2020, at https://doi.org/10.3133/ wri954066. 
Adams, G.P., Runkle, D., Rea, A., and Cederstrand, J.R., 1997, Digital data sets that describe aquifer characteristics of the alluvial and terrace deposits along the Cimarron River from Freedom to Guthrie in northwestern Oklahoma: U.S. Geological Survey Open File Report 96-445, variously paged, accessed August 28, 2020, at https://doi.org/10.3133/ ofr96445.

Ahlfeld, D.P., and Hoque, Y., 2008, Impact of simulation model solver performance on ground water management problems: Ground Water, v. 46, no. 5, p. 716-726, accessed August 27, 2020, at https://doi.org/10.1111/j.17456584.2008.00454.x.

Banta, E.R., 2014, Two graphical user interfaces for managing and analyzing MODFLOW groundwater-model scenarios: U.S. Geological Survey Techniques and Methods, book 6, chap. A50, 38 p., accessed August 28, 2020, at https://doi.org/10.3133/tm6A50.

Barlow, P.M., and Leake, S.A., 2012, Streamflow depletion by wells-Understanding and managing the effects of groundwater pumping on streamflow: U.S. Geological Survey Circular 1376, 84 p., accessed August 27, 2020, at https://doi.org/10.3133/cir1376.

Bingham, R.H., and Bergman, D.L., 1980, Reconnaissance of the water resources of the Enid quadrangle, northcentral Oklahoma: Norman, Oklahoma, Oklahoma Geological Survey, Hydrologic Atlas no. 7, pl. 1, accessed June 29, 2020, at http://ogs.ou.edu/docs/hydrologicatlases/ HA7P1.pdf.

Charles, M., 2014, Economic trends for Stillwater and Payne County look good: Stillwater News Press, accessed, January 9, 2021, at https://www.stwnewspress.com/news/ economic-trends-for-stillwater-and-payne-county-lookgood/article_ea9c320c-5fd6-11e4-b352-e33d9f8dd329.html.

Chow, V.T., 1959, Open-channel hydraulics: New York, McGraw-Hill, 680 p.

Darcy, H., 1856, Les Fontances publiques de la ville de Dijon: Paris, Victor Dalmont, 647 p.

Doherty, J.E., and Hunt, R.J., 2010, Approaches to highly parameterized inversion-A guide to using PEST for groundwater-model calibration: U.S. Geological Survey Scientific Investigations Report 2010-5169, 59 p., accessed June 1, 2019, at https://doi.org/10.3133/sir20105169.

Domagalski, J.L., and Johnson, H., 2012, Phosphorus and groundwater-Establishing links between agricultural use and transport to streams: U.S. Geological Survey Fact Sheet 2012-3004, 4 p., accessed October 14, 2020, at https://doi.org/10.3133/fs20123004.
Ellis, J.H., Mashburn, S.L., Graves, G.M., Peterson, S.M., Smith, S.J., Fuhrig, L.T., Wagner, D.L., and Sanford, J.E., 2017, Hydrogeology and simulation of groundwater flow and analysis of projected water use for the Canadian River alluvial aquifer, western and central Oklahoma (ver. 1.1, March 2017): U.S. Geological Survey Scientific Investigations Report 2016-5180, 64 p., 7 pls., accessed August 18, 2020, at https://doi.org/10.3133/sir20165180.

Esri, 2011, ArcGIS Desktop-Release 10: Redlands, California, Esri, Inc., accessed July, 28, 2020, at https:/ /desktop.arcgis.com/en/arcmap/.

Freeze, R.A., and Cherry, J.A., 1979, Groundwater: Englewood Cliffs, New Jersey, Prentice Hall, 604 p.

Garden, A.J., 1973, Geology of western Payne County, Oklahoma: Stillwater, Oklahoma, Oklahoma State University, master's thesis, 70 p., accessed August 21, 2020, at https://shareok.org/bitstream/handle/11244/23797/Thesis1973-G218g.pdf? sequence $=1$.

Greig, P.B., 1959, Geology of Pawnee County, Oklahoma: Oklahoma Geological Survey Bulletin 83, 188 p., accessed July 19, 2020, at http://ogs.ou.edu/docs/bulletins/ B40-CC.pdf.

Guy, H.P., 1969, Laboratory theory and methods for sediment analysis: U.S. Geological Survey Techniques of WaterResources Investigations, chap. C1, book 5, 58 p., accessed August 28, 2020, at https://doi.org/10.3133/twri05C1.

Harbaugh, A.W., 2005, MODFLOW2005-The U.S. Geological Survey modular ground-water model-The ground-water flow process: U.S. Geological Survey Techniques and Methods, book 6, chap. A16, [variously paged], accessed August 21, 2020, at https://doi.org/ $10.3133 / \mathrm{tm} 6 \mathrm{~A} 16$.

Harbaugh, A.W., Banta, E.R., Hill, M.C., and McDonald, M.G., 2000, MODFLOW2000-The U.S. Geological Survey modular groundwater model - User guide to modularization concepts and the groundwater flow process: U.S. Geological Survey Open-File Report 00-92, 121 p., accessed August 21, 2020, at https://doi.org/10.3133/ ofr200092.

Hargreaves, G.H., and Samani, Z.A., 1985, Reference crop evapotranspiration from temperature: Applied Engineering in Agriculture, v. 1, no. 2, p. 96-99, accessed July 18, 2020, at https://doi.org/10.13031/2013.26773.

Healy, R.W., and Cook, P.G., 2002, Using groundwater levels to estimate recharge: Hydrogeology Journal, v. 10, no. 1, p. 91-109, accessed August 2, 2020, at https://doi.org/ 10.1007/s10040-001-0178-0. 
Heath, R.C., 1983, Basic ground-water hydrology: U.S. Geological Survey Water-Supply Paper 2220, 84 p., accessed August 27, 2020, at https://doi.org/ $10.3133 /$ wsp2220.

Heran, W.D., Green, G.N., and Stoeser, D.B., 2003, A digital geologic map database for the State of Oklahoma (ver. 1.1): U.S. Geological Survey Open-File Report 2003-247, [variously paged], accessed August 21, 2020, at https://doi.org/ $10.3133 /$ ofr03247.

Hill, M.C., Banta, E.R., Harbaugh, A.W., and Anderman, E.R., 2000, MODFLOW2000, the U.S. Geological Survey modular ground-water model; user guide to the observation, sensitivity, and parameter-estimation processes and three post-processing programs: U.S. Geological Survey OpenFile Report 2000-184, 209 p., accessed August 3, 2020, at https://doi.org/10.3133/ofr00184.

Horizon Systems Corporation, 2019, National Hydrography Dataset Plus (NHDPlus) version 2: Horizon Systems Corporation online database, accessed March 4, 2019, at https://nhdplus.com/NHDPlus/NHDPlusV2_11.php.

Koller, M., Chatelain, J.L., Guillier, B., Duval, A.M., Atakan, K., Lacave, C., and Bard, P.Y., 2004, SESAME-Team, Practical user guidelines and software for the implementation of the $\mathrm{H} / \mathrm{V}$ ratio technique-Measuring conditions, processing method and results interpretation in 13th World Conference on Earthquake Engineering, Vancouver, British Columbia, Canada, August 16, 2004, Proceedings: Sesame Project Team, World Conference on Earthquake Engineering, Paper No. 3132, accessed April 23, 2020, at http://citeseerx.ist.psu.edu/viewdoc/download?doi= 10.1.1.626.6948\&rep=rep1\&type=pdf.

Logan, B.W., Rezak, R., and Ginsburg, R.N., 1964, Classification and environmental significance of algal stromatolites: Journal of Geology, v. 72, no. 1, p. 68-83, accessed August 19, 2020, at https://doi.org/ $10.1086 / 626965$.

Lohman, S.W., and others, 1972, Definitions of selected groundwater terms revisions and conceptual refinements: U.S. Geological Survey Water-Supply Paper 1988, 21 p., accessed August 14, 2020, at https://doi.org/ $10.3133 /$ wsp1988.

Mashburn, S.L., and Magers, J., 2011, Potentiometric surface in the Central Oklahoma (Garber-Wellington) aquifer, Oklahoma, 2009: U.S. Geological Survey Scientific Investigations Map 3147, 1 sheet, scale 1:24,000, accessed August 19, 2020, at https://doi.org/10.3133/sim3147.
Mashburn, S.L., Ryder, D.W., Neel, C.R., Smith, S.J., and Correll, J.S., 2014, Hydrogeology and simulation of groundwater flow in the Central Oklahoma (Garber-Wellington) Aquifer, Oklahoma, 1987 to 2009, and simulation of available water in storage, 2010-2059 (ver. 2.0, October 2019): U.S. Geological Survey Scientific Investigations Report 2013-5219, 92 p., accessed August 18, 2020, at https://doi.org/10.3133/sir20135219.

Merritt, M.L., and Konikow, L.F., 2000, Documentation of a computer program to simulate lake-aquifer interaction using the MODFLOW ground-water flow model and the MOC3D solute-transport model: U.S. Geological Survey WaterResources Investigations Report 00-4167, 146 p., accessed October 14, 2020, at https://doi.org/10.3133/wri004167.

Nakayama, E., 1955, The subsurface geology of southeastern Payne County, Oklahoma: University of Oklahoma unpublished master's thesis on file in the Geology Library and University Library, Norman, Oklahoma.

National Agricultural Statistics Service, 2018a, CropScapeCropland data layer, 2016 and 2017: U.S. Department of Agriculture, accessed July 5, 2018, at https://nassgeodat a.gmu.edu/CropScape/.

National Agricultural Statistics Service, 2018b, CropScapeCropland data layer, 2018: U.S. Department of Agriculture, accessed January 6, 2020, at https://nassgeodata.gmu.edu/ CropScape/.

National Oceanic and Atmospheric Administration, 2019, Dataset gallery: National Oceanic and Atmospheric Administration, National Weather Service web page, accessed December 3, 2019, at https://www.weather.gov/ jetstream/climate_max.

Niswonger, R.G., Panday, S., and Ibaraki, M., 2011, MODFLOW-NWT, a Newton formulation for MODFLOW-2005: U.S. Geological Survey Techniques and Methods, book 6, chap. A37, 44 p., accessed August 27, 2020, at https://doi.org/10.3133/tm6A37.

Noble, R.L., 1973, Depositional and directional features of a braided-meandering stream: Oklahoma State University master's thesis, accessed August 27, 2020, at https://shareok.org/handle/11244/23901.

Oklahoma Climatological Survey, 2020, Oklahoma Mesonet: Oklahoma Climatological Survey online database, accessed January 22, 2020, at http://climate.ok.gov/cgi-bin/public/ climate.timeseries.one.cgi.

Oklahoma Geological Survey, 2019, The Oklahoma Geological Survey Statewide Seismic Network: Oklahoma Geological Survey web page, accessed June 3, 2020, at https://www.ou.edu/ogs/research/earthquakes/ seismicstations. 
Oklahoma Water Resources Board [OWRB], 2012, Basin 71, in Upper Arkansas watershed planning region report (ver. 1.1): Oklahoma Water Resources Board, p. 95-103, accessed August 7, 2020, at http://www.owrb.ok.gov/ supply/ocwp/pdf_ocwp/WaterPlanUpdate/regionalreports/ OCWP_UpperArkansas_Region_Report.pdf.

Oklahoma Water Resources Board [OWRB], 2019a, OWRB open data-Permitted groundwater wells: Oklahoma Water Resources Board online database, accessed October 25, 2019, at https://home-owrb.opendata.arcgis.com/datasets/ permitted-groundwater-wells.

Oklahoma Water Resources Board [OWRB], 2019b, OWRB open data-Permitted surface water diversion points: Oklahoma Water Resources Board online database, accessed October 25, 2019, at https://home-owrb. opendata.arcgis.com/datasets/permitted-surface-waterdiversion-points.

Rantz, S.E., and others, 1982, Measurement and computation of streamflow-Volume 2. Computation of discharge: U.S. Geological Survey Water-Supply Paper 2175, p. 285-631, accessed August 25, 2020, at https://doi.org/ $10.3133 /$ wsp2175.

Reed, E.W., Mogg, J.L., Barclay, J.E., and Peden, G.H., 1952, Ground-water resources of the terrace deposits along the northeast side of the Cimarron River in Alfalfa, Garfield, Kingfisher, and Major Counties, Oklahoma: Oklahoma Planning and Resources Board, Division of Water Resources Bulletin 9, 101 p.

Reilly, T.E., 2001, System and boundary conceptualization in ground-water flow simulation: U.S. Geological Survey Techniques of Water-Resources Investigations, book 3, chap. B8, 26 p., accessed September 1, 2020, at https://doi.org/10.3133/twri03B8.

Roeloffs, E.A., Nelms, D.L., and Sheets, R.A., 2015, Widespread groundwater-level offsets caused by the Mw 5.8 Mineral, Virginia, earthquake of 23 August 2011, in Horton, J.W., Jr., Chapman, M.C., and Green, R.A., eds., The 2011 Mineral, Virginia, earthquake, and its significance for seismic hazards in eastern North America: Geological Society of America Special Paper 509, p. 117-136, accessed October 15, 2020, at https://doi.org/10.1130/2014.2509(07).

Ryder, P.D., 1996, Groundwater atlas of the United StatesSegment 4, Oklahoma, Texas: U.S. Geological Survey Hydrologic Atlas 730-E, 30 p., accessed August 21, 2020, at https://doi.org/10.3133/ha730E.

Shelton, J.W., 1973, Models of sand and sandstone deposits - A methodology for determining sand genesis and trend: University of Oklahoma, Oklahoma Geological Survey Bulletin 118, 122 p., accessed February 10, 2021, at http://ogs.ou.edu/docs/bulletins/B118.pdf.
Shelton, J.W., and Noble, R.L., 1974, Depositional features of braided-meandering stream: American Association of Petroleum Geologists Bulletin, v. 58, no. 4, p. 742-752.

Shelton, J.W., Ross, J.S., Garden, A.J., and Franks, J.L., 1985, Geology and mineral resources of Payne County, Oklahoma: Oklahoma Geological Survey Bulletin 137, 85 p., accessed June 15, 2020, at http://ogs.ou.edu/docs/ bulletins/B137.pdf.

Smith, S.J., Ellis, J.H., Wagner, D.L., and Peterson, S.P., 2017, Hydrogeology and simulated groundwater flow and availability in the North Fork Red River aquifer, southwest Oklahoma, 1980-2013: U.S. Geological Survey Scientific Investigations Report 2017-5098, 107 p., accessed August 27, 2020, at https://doi.org/10.3133/sir20175098.

Smith, J.S., Ellis, J.H., Paizis, N.C., Becker, C.J., Wagner, D.L., Cornell, J.S., and Hernandez, R.J., 2021, Hydrogeology and model-simulated groundwater availability in the Salt Fork Red River aquifer, southwestern Oklahoma, 1980-2015: U.S. Geological Survey Scientific Investigations Report 2021-5003, 85 p., accessed June 11, 2021, at https://doi.org/10.3133/sir20215003.

Thornthwaite, C.W., and Mather, J.R., 1957, Instructions and tables for computing potential evapotranspiration and the water balance - Centerton, N.J.: Laboratory of Climatology Publications in Climatology, v. 10, no. 3, p. 185-311.

Trevisan, A.R., and Paizis, N.C., 2021, MODFLOW-NWT model used for the simulation of the Cimarron River alluvial aquifer in the Pawnee Nation Tribal jurisdictional area in Payne County, Oklahoma, 2016-17: U.S. Geological Survey data release, https://doi.org/10.5066/P9WZGYQF.

Tromino, 2012, Tromino Portable ultra-light acquisition system for seismic noise and vibrations-User's manual. Patent no. WO2006011021 (A1): Treviso, Italy, Micromed.

U.S. Geological Survey [USGS], 1966, Groundwater in the Cimarron River Basin, New Mexico, Colorado, Kansas, and Oklahoma: U.S. Geological Survey Open-File Report 66-159, p. 51, accessed June 16, 2020, at https://doi.org/ $10.3133 /$ ofr66159.

U.S. Geological Survey [USGS], 2015, The National Map: U.S. Geological Survey National Geospatial Program, accessed January 15, 2015, at https://ned.usgs.gov/ index.html.

U.S. Geological Survey [USGS], 2019, USGS water data for the Nation: U.S. Geological Survey National Water Information System database, accessed August 27, 2019, at https://doi.org/10.5066/F7P55KJN. 
Wahl, K.L., and Wahl, T.L., 1995, Determining the flow of Comal Springs at New Braunfels, Texas, in Proceedings of Texas Water '95, a component conference of the First International Conference on Water Resources Engineering, San Antonio, Texas, August 16-17, 1995: American Society of Civil Engineers, p. 77-86, accessed June 15, 2021, at h ttps://www.usbr.gov/tsc/techreferences/hydraulics_lab/pubs/ PAP/PAP-0708.pdf.

Wentworth, C.K., 1922, A scale of grade and class terms for clastic sediments: Journal of Geology, v. 30, no. 5, p. 377-392, accessed August 28, 2020, at https://doi.org/ $10.1086 / 622910$.

Westenbroek, S.M., Kelson, V.A., Dripps, W.R., Hunt, R.J., and Bradbury, K.R., 2010, SWB-A modified Thornthwaite-Mather Soil-Water-Balance code for estimating groundwater recharge: U.S. Geological Survey Techniques and Methods, book 6, chap. A31, 60 p., accessed August 27, 2020, at https://doi.org/ 10.3133/tm6A31.
White, W.N., 1932, A method of estimating ground-water supplies based on discharge by plants and evaporation from soil-Results of investigations in Escalante Valley, Utah: U.S. Geological Survey Water Supply Paper 659-A, 105 p., accessed June 5, 2020, at https://doi.org/10.3133/wsp659A.

Wickham, J.D., Homer, C.G., Vogelmann, J.E., McKerrow, A., Mueller, R., Herold, N., and Coulston, J., 2014, The multiresolution land characteristics (MRLC) consortium-20 years of development and integration of USA national land cover data: Remote Sensing, v. 6, no. 8, p. 7424-7441, accessed August 27, 2020, at https://doi.org/10.3390/ rs6087424.

Winter, T.C., Harvey, J.W., Franke, O.L., and Alley, W.M., 1998, Ground water and surface water-A single resource: U.S. Geological Survey Circular 1139, 79 p., accessed October 6, 2020, at https://doi.org/10.3133/cir1139. 

For more information about this publication, contact Director, Oklahoma-Texas Water Science Center U.S. Geological Survey

1505 Ferguson Lane

Austin, TX 78754-4501

For additional information, visit https://www.usgs.gov/centers/ot-water

Publishing support provided by Lafayette Publishing Service Center 
